A FISHERIES EVALUATION OF THE WESTSIDE DITCH AND WAPATO CANAL FISH SCREENING FACILITIES SPRING 1989

Annual Report 1990

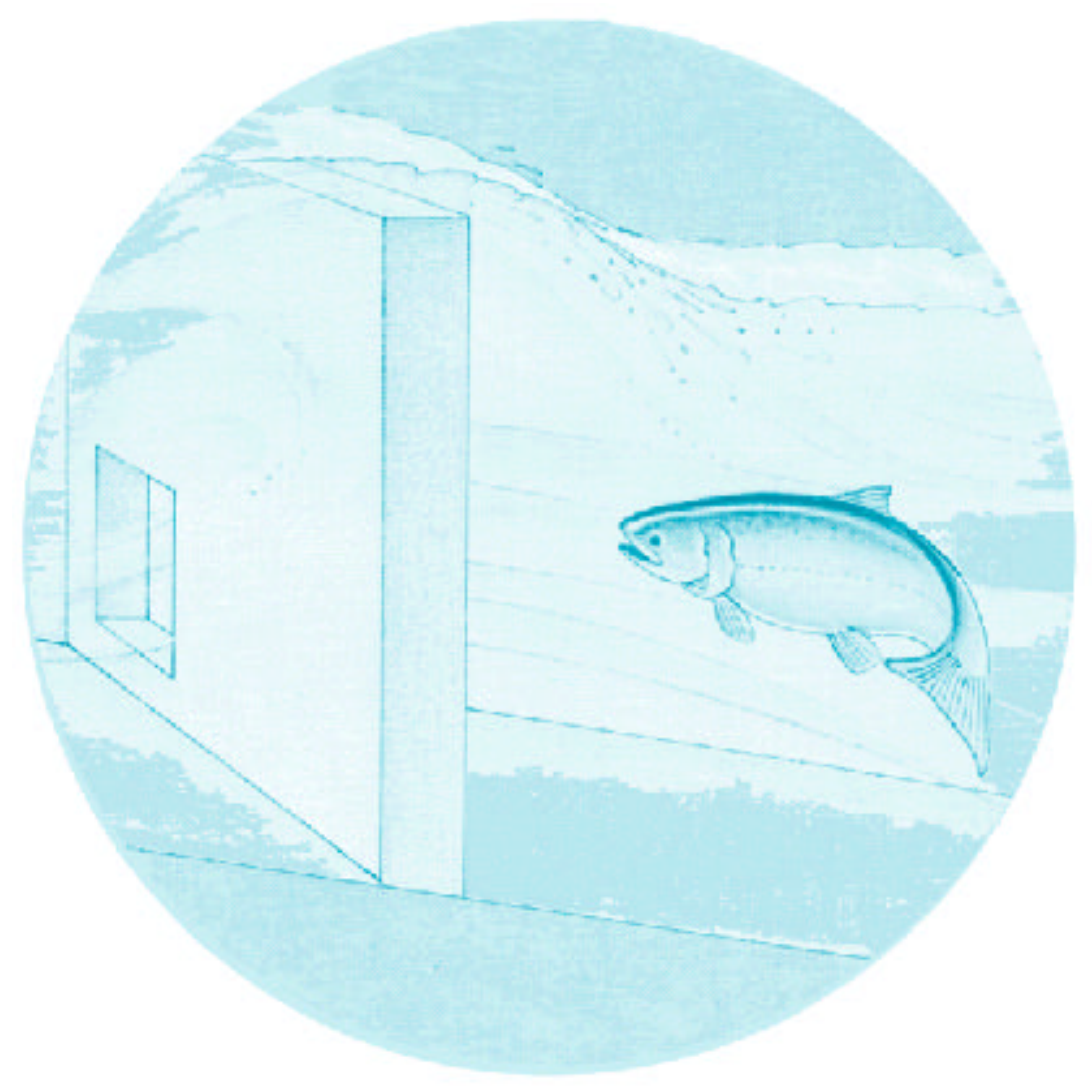

DOE/BP-01830-8 
This report was funded by the Bonneville Power Administration (BPA), U.S. Department of Energy, as part of BPA's program to protect, mitigate, and enhance fish and wildlife affected by the development and operation of hydroelectric facilities on the Columbia River and its tributaries. The views of this report are the author's and do $\mathrm{r}$ necessarily represent the views of BPA.

This document should be cited as follows:

Neitzel,Duane A.; C. Scott Abernethy, E. William Lusty, Pacific Northwest Laboratory, Thomas Clune. Project

Manager, U. S. Department of Energy, Bonneville Power Administration, Division of Fish and Wildlife, Project No.

1985-62, Contract No. DE-AC06-76RL01830, 94 electronic pages (BPA Report DOE/BP-01830-8)

This report and other BPA Fish and Wildlife Publications are available on the Internet at:

\section{http://www.efw.bpa.gov/cgi-bin/efw/FW/publications.cgi}

For other information on electronic documents or other printed media, contact or write to:

Bonneville Power Administration

Environment, Fish and Wildlife Division

P.O. Box 3621

905 N.E. 11th Avenue

Portland, OR 97208-3621

Please include title, author, and DOE/BP number in the request. 


\section{A FI SHER ES EVALUATI ON OF THE WESTSIDE DITCH AND WAPATO CANAL FISH SCREENING FACILITIES \\ SPRIN G 1989}

\section{Annual Report}

\section{BY}

Duane A Nei tzel

C. Scott Abernethy

E. Vil I i am Lusty

Pacific Northwest Laboratory

\section{Prepared For}

Thonas Cl une. Proj ect Manager

U. S. Depart ment of Energy

Bonnevi I l e Pouer Admi ni strati on

103 South 3rd Street

Yaki ma, Whshi ngt on 98901

Proj ect No. 85- 62

Contract Nb. DE- AC06-76RL0 1830 
The Bonnevi l le Power Admini stration. the Uni ted States Bureau of Recl anati on. and the Whshi ngt on State Departnent of Ecol ogy are fundi ng the constructi on and eval uation of fish passage and protection facilities at i rri gati on and hydroel ectric di versi ons in the Yaki na Ri ver Basi $n$, Whshi ngt on State. Thi s constructi on i mpl ements Secti ons 903 (d) and 803 (b) of the Northuest Power Pl anni ng Counci I' s 1984 and 1987 Col unbi a Ri ver Basi n Fish and Vild if e Prograns. 1 The prograns provide offsite enhancenent to compensate for $f i$ sh and wi I li fe I osses caused by hydroel ectric devel opment throughout the Col unbi a Ri ver Basi $n$. and they address nat ural propagati on of sal mon to hel $p$ mitigate the i mpact of i rrigation in the Yaki ma Ri ver Basi $n$.

The Westsi de Ditch and Whato Screens are tuo of the juveni l e screeni ng facilities. This report eval uates the effectiveness of the screens faci I iti es for i ntercepti ng and returni ng $j$ uveni l e sal noni ds unharned to the Yaki ma Ri ver from whi ch they were di verted. Studi es were conducted in which fish were rel eased upstream of or withi $n$ the screen facilities and capt ured in the di versi on that transfers them back to the river. Results i ndi cated that the screens safel y di verted fi sh fromthe canal s to the ri ver.

The st udy emphasi zed sal moni ds. Test fi sh were steel head Oncor hynchus myki ss smol ts. spring chi nook sal mon 0 . tshawytscha smol ts. and rai nbow trout 0 . myki ss fry. Eval uations were conducted during typical spring fl ous in the di version.

1 Northwest Power PI anni ng Counci I (NPPC). 1984. Columbia River Basin Eish and Wildife Program Northwest Power PI anni ng Council, Port l and, Oregon.

Northwest Power PI anni ng Counci I (NPPC). 1987. Col unbia Ri ver Basin Fish and Vild ife Proaram Northwest Power PI anning Council, Portl and, Oregon. . 
The i nvol vement and cooperati on of many peopl e during these st udi es were greatl y appreci at ed. Thonas J. C une. Bonnevi I l e Power Adni ni strati on was the Proj ect Manager. Chuck Kel I er and Ed Spegl er, Bureau of Recl anati on, and thei $r$ operations and mai ntenance staffs provided critical support and assi stance during si te preparation and data collection. Jack Wi tehurst. Uest si de I rri gati on Company. hel ped with the fl ow adj ust nents and mai ntenance we needed at Westsi de. J i m Cumi ns and J i m Lee, Whshi ngt on Department of Vild i fe, and Bi I Janes, Whshingt on Department of Fi sheri es hel ped with the procurement of test fish. Jeanne Si mpson and Sal Iy Whmpl er hel ped with the stati stical anal ysis. Bill Hanf. Dennis Dauble. and Pete Test hel ped conduct the field tests. The manuscript was revi ewed by Andy PI ymal e and Denni s Daubl e. 
We eval uated the effecti veness of new fish screening faciliti es in the Westsi de Ditch and Whato Canal in south-central Whshi ngt on State. The screen integrity tests i ndi cated that test fish rel eased in front of the screens could enter the canal behi nd the screens. At Westsi de Ditch, between $6 \%$ and $25 \%$ of the zero-age fry passed through the rotary drum screens. The $6 \%$ esti mate is based on tests with rai nbow trout Oncorhynchus myki ss f ry. The $25 \%$ esti mate is based on moni toring chi nook sal mon 0 . tshawytscha fry that were di verted from the river i nto the i rrigation di t ch.

At Westsi de Ditch, we esti mated that $1.8 \%$ of st eel head 0 . myki ss snol ts and $0.3 \%$ of chi nook sal non snol ts rel eased during tests were descal ed. The ti me requi red for $50 \%$ of the test fi sh to exit from the Westsi de Ditch Screen forebay was 3 to $8 \mathrm{~h}$ for chi nook sal mon snol ts and up to $28 \mathrm{~h}$ for st eel head snol ts.

Methods used i $\mathbf{n} 1988$ were first used at Sunnysi de i $\mathbf{n} 1985$ and were used i n subsequent years at $\mathrm{Ri}$ chl and. Toppeni sh/ Sat us. Whato. and Toppeni sh Creek. The methods and 1985 through 1987 results have been revi ewed by the Whshi ngt on State Department of Fi sheries, U.S. Fi sh and Vill dl ife Service, Nati onal Mari ne Fi sheri es Servi ce, Northuest Power PI anni ng Counci I. and the Yaki ma I ndi an Nation. 


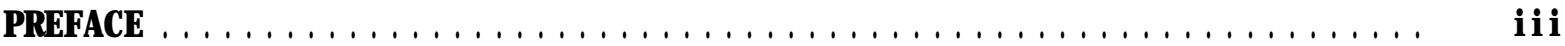

ACKNOVLEDGENTS. .....................................

ABSTRACT $\ldots \ldots \ldots \ldots \ldots \ldots \ldots \ldots \ldots \ldots \ldots \ldots \ldots \ldots \ldots \ldots \ldots \ldots \ldots \ldots \ldots$

I NTRODUCTI ON , , , , , , , , , , , , , , , , , , , , , , , , , , , ,

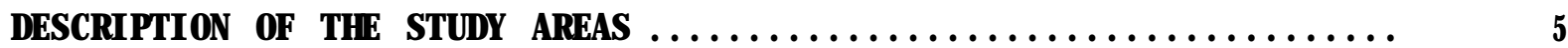

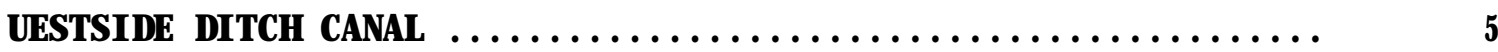

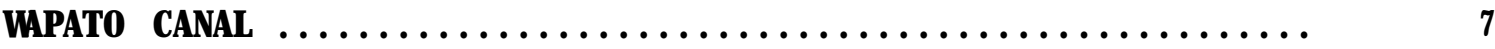

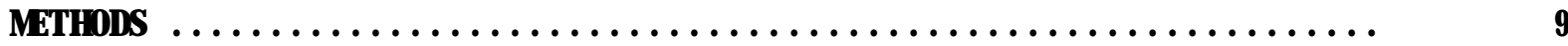

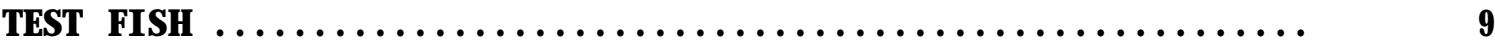

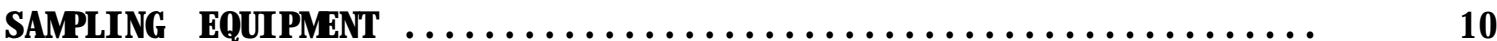

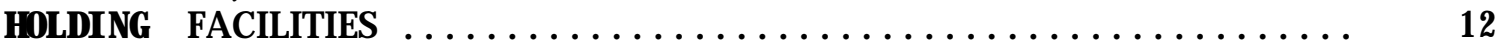

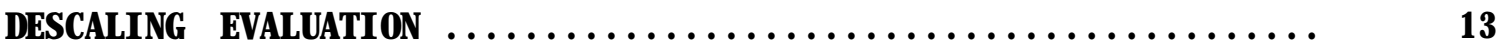

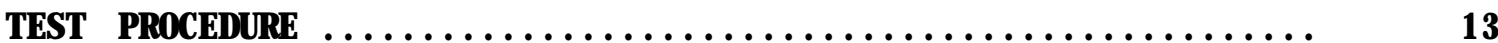

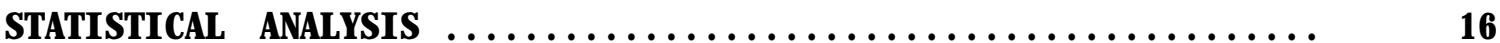

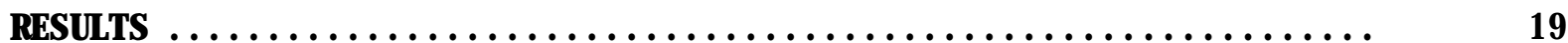

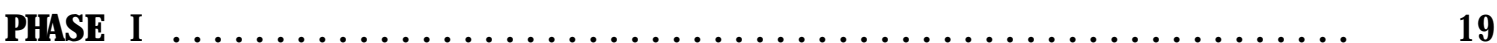

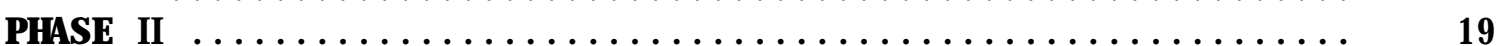

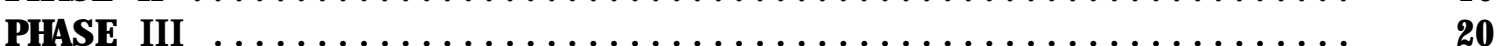

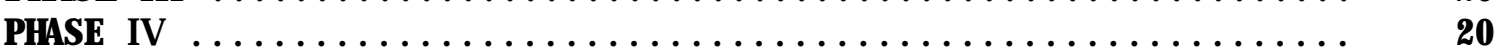

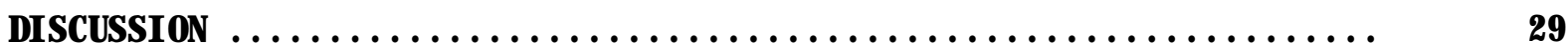

FI SH SURM VAL AT SCREEN NG FACI LITI ES . . . . . . . . . . . . . . . .

POTENII AL FOR PREDATI ON AT SCREEN NG FACI LI TI ES . . . . . . . . . . . . . 29

POTENII AL FOR FI SH DELAY AT SCREEN NG FACI LI TI ES . . . . . . . . . . . . . 30

FI SH PASSAGE THROUGH OR OVER ROTARY DRUM SCREENS . . . . . . . . . . . 30

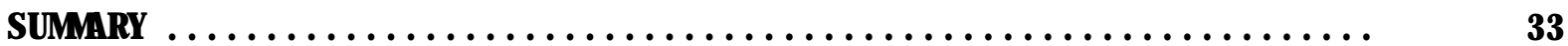

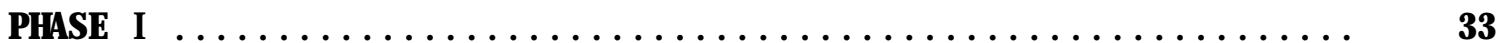

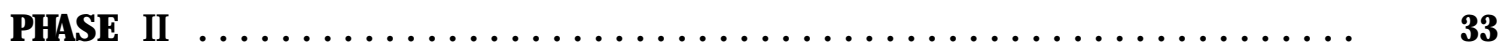

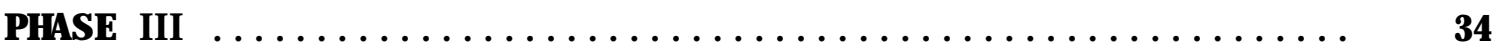

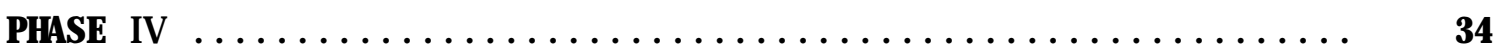

RECOMMENDATI ONS , , , , , , , , , , , , , , , , , , , , , , , , , , ,

REFERENCES , , , , , , , , , , , , , , , , , , , , , , , , , ,

APPEND X A : VDRK PLAN, , , , , , , , , , , , , , , , , , , , , 
APPENDI $X$ B - RELEASE AND CAPTURE DATA FROM SUNYYI DE. RI CHLAND. TOPPEN SH SATUS. MAPATO TOPPEN SH CREEK AND WESTSIDE DITCH FISH SCREENING FACILITIES....................... 


\section{EIGURES}

1. Yaki ma Ri ver Basi n, I ncl udi ng Locati ons of the Westsi de Ditch and Whato Canal Fi sh Screeni ng Faci I iti es and Other Fi sh Protection and Passage Facilities......................

2. Yaki ma Ri ver Basi $n$ Showi ng Locati on of the Whato Canal Fi sh Screeni ng Facility in the Westsi de Ditch Canal Fi sh Screeni ng Faci l ity.

3. Fl ow Control Structure and Fi sh Bypass System in the Westsi de

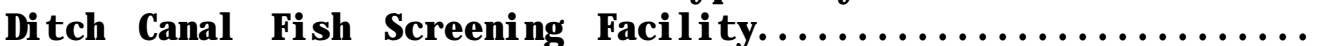

4. Fl ow Control Struct ure and Fi sh Bypass System in the Whato

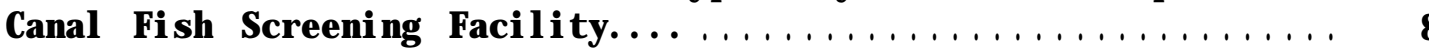

5. I ncl i ned PI ane Used at the Westsi de Di tch Canal Fi sh Screeni ng Faci I i ty, Spri ng 1989...............................

6. Fyke Net Used i n Pi pe Tests at the Whato Screens, Spri ng 1989.

7. Fyke Nets Used i n I ntegrity Tests at the Westsi de Ditch Screens. Spring 1989

8. Movenent of Steel head Oncorhynchus myki ss Snol ts Based on the Capt ure of Test Fi sh at the Westsi de Di tch Canal Fi sh Screening Facility, Spring 1989

9. Mbvenent of Spring Chi nook Sal mon Ocorhynchus t shawyt scha Snol ts Based on the Capt ure of Test Fi sh at the Westsi de Ditch Canal Fi sh Screeni ng Facility, Spring 1989................

10. Mbvement of Rai nbow Trout Oncorhynchus myki ss Fry Based on the Capt ure of Test Fi sh at the Westsi de Di tch Canal Fi sh Screeni ng Facility, Spring 1989.... 
1. Descal ing and Mrtal ity Data from Rel ease and Capt ure Tests wi th Steel head Oncorhynchus myki ss and Spring Chi nook Sal mon 0. tshawytschSm ol ts at the Westside Ditch Fish

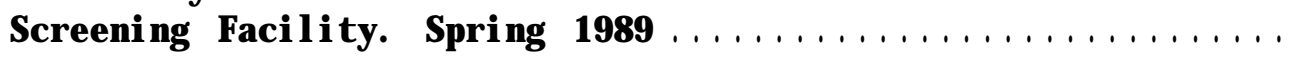

2. Est i mated Ti me to Capt ure $50 \%$ of St eel head Oncorhynchus myki ss and Spri ng Chi nook Sal non 0. tshawytscha Snol ts Rel eased in Descal ing Tests at Uestsi de Ditch Fi sh Screening

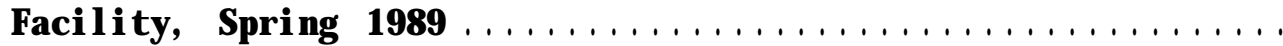

3. Percentage of Spring Chi nook Sal non Oncorhynchus tshawytscha Snol ts Descal ed in Pi pe Tests at the Whpato Canal Fi sh

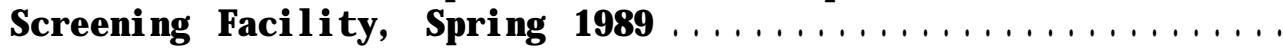

4. Capt ure Data for Rai nbow Trout Oncorhynchus myki ss Fry Rel eased During Screen I ntegrity Tests at the Westsi de Ditch Fi sh Screeni ng Facility, Spring $1989 \ldots \ldots \ldots \ldots \ldots \ldots \ldots \ldots \ldots \ldots \ldots$

5. Capt ure Data for Chi nook Sal mon Oncorhynchus tshawytscha Fry Caught During Screen I ntegrity Tests at the Westsi de Ditch Canal Fi sh Screeni ng Facility, Spri ng $1989 \ldots \ldots \ldots \ldots \ldots \ldots \ldots . . \ldots$

6. Capt ure Effi ci ency of the I ncl i ned PI ane and Fyke Nets Used Duri ng Screen Integrity Tests at the Westsi de Di tch Canal Fi sh Screeni ng Facility, Spri ng $1989 \ldots \ldots \ldots \ldots \ldots \ldots \ldots \ldots \ldots . . \ldots . \ldots 26$

B. I Percentage of Coho Sal non Oncorhynchus ki sutch Snol ts Descal ed or Killed During Tests of the I ncli ned PI ane at Sunnysi de

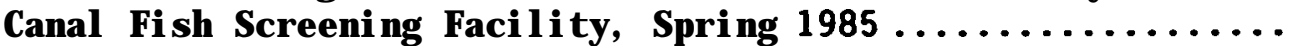

8. 2 Percentage of Steel head Oncorhynchus myki ss and Chi nook Sal mon 0. tshawytscha Snol ts Descal ed or KII ed During Tests of the Fyke Net at Sunnysi de Canal Fi sh Screeni ng Facility, Spring $1985 \ldots \ldots \ldots \ldots \ldots \ldots \ldots \ldots \ldots \ldots \ldots \ldots \ldots \ldots$

B. 3 Percentage of Steel head Oncorhynchus mykiss Snol ts Descal ed Before Bei ng Used in Tests at Sunnysi de Canal Fi sh Screening Facility, Spring $1985 \ldots \ldots \ldots \ldots \ldots \ldots \ldots \ldots \ldots \ldots \ldots \ldots \ldots \ldots$

B. 4 Percentage of Chi nook Sal mon Oncorhynchus tshawytscha Snol ts Descal ed Bef ore Bei ng Used in Tests at Sunnysi de Canal Fi sh Screeni ng Facility, Spring $1985 \ldots \ldots \ldots \ldots \ldots \ldots \ldots \ldots \ldots \ldots$

B. 5 Percentage of Steel head Oncorhynchus myki ss Descal ed Snol ts or Killed in Each Test at Sunnysi de Canal Fi sh Screeni ng Facility, Spring $1985 \ldots \ldots \ldots \ldots \ldots \ldots \ldots \ldots \ldots \ldots \ldots \ldots$ 
8. 6 Percentage of Chi nook Sal mon Oncorhynchus tshawytscha Snol ts Descal ed or KII ed in Each Test at Sunnysi de Canal Fi sh Screeni ng Faci I ity, Spri ng $1985 \ldots \ldots \ldots \ldots \ldots \ldots \ldots \ldots \ldots \ldots$

8. 7 Scal e Loss for Hatchery-Rel eased and Nati ve Fi sh Capt ured During Tests at Sunnysi de Canal Fi sh Screeni ng Facility,

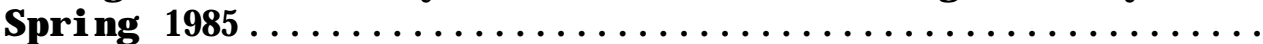

B. 8 Percentage of Chi nook Sal non Oncorhynchus tshawytscha Snol ts Descal ed or Killed During Tests of the I ncl i ned PI ane at Ri chl and Canal Fi sh Screeni ng Facility, Spri ng $1986 \ldots \ldots \ldots \ldots$

B. 9 Percentage of Chi nook Sal mon Oncorhynchus tshawytscha Snol ts Descal ed or Killed During Tests of the Fyke Net at Ri chl and Canal Fi sh Screeni ng Facility, Spri ng $1986 \ldots \ldots \ldots \ldots \ldots \ldots$

6. 10 Percentage of Steel head Oncorhynchus mykiss Snol ts Descal ed Before Bei ng Used i n Tests at Ri chl and Canal Fi sh Screeni ng

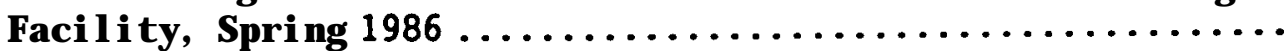

B.11 Percentage of Chi nook Sal mon Oncorhynchus tshawytscha Snol ts Descal ed Before Bei ng Used i n Tests at Ri chl and Canal Fi sh Screeni ng Facility, Spring $1986 \ldots \ldots \ldots \ldots \ldots \ldots \ldots \ldots \ldots$

8. 12 Descal ing and Mrtal ity Data from Rel ease and Capture Tests wi th Steel head Oncorhynchus nyks Snol ts at Ri chl and Canal

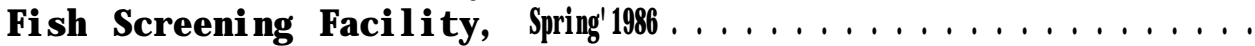

8. 13 Descal ing and Mrtal ity Data from Rel ease and Capt ure Tests with Spring Chi nook Sal mon Oncorhynchus tshawytscha Snol ts at Ri chl and Canal Fi sh Screeni ng Facility, Spring 1986.......

8. 14 Esti mated Ti ne to Catch $50 \%$ and $95 \%$ of Test Fi sh Capt ured at Ri chl and Canal Fi sh Screeni ng Facility, Spri ng $1986 \ldots . .$.

B. 15 Scal e Loss for Hatchery-Rel eased and Nati ve Fi sh Capt ured Duri ng Tests at $\mathrm{Ri}$ chl and Canal Fi sh Screeni ng Faci l ity,

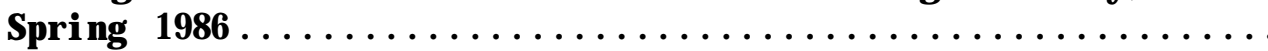

8. 16 Percentage of Steel head Oncorhynchus myks Snol ts Descal ed Bef ore Bei ng Used in Tests at Toppeni sh/Sat us Canal Fi sh Screeni ng Faci I i ty, Spri ng 1986.

8. 17 Descal ing and Mrtal ity Data from Rel ease and Capt ure Tests wi th Steel head Oncorhynchus myks Snol ts at Toppeni sh/ Sat us Canal Fi sh Screeni ng Faci I i ty, Spri ng $1986 \ldots \ldots \ldots \ldots \ldots \ldots \ldots$ 
8. 18 Esti mated Ti ne to Catch $50 \%$ and $95 \%$ of Test Fi sh Capt ured at Toppeni sh/ Sat us Canal Fi sh Screeni ng Facility,

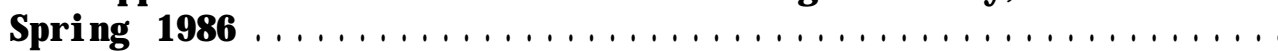

B.19 Scal e Loss for Hatchery-Reared and Nat ure Fi sh Capt ured During Tests at Toppeni sh/ Sat us Canal Fi sh Screeni ng Facility, Spring 1986

8. 20 Percentage of Spring Chi nook Sal non Oncorhynchus tshawyt scha and St eel head 0 . myki ss Snol ts Descal ed or $\mathrm{K}$ II ed During Tests of the I ncl i ned PI ane at Wato Canal Fi sh

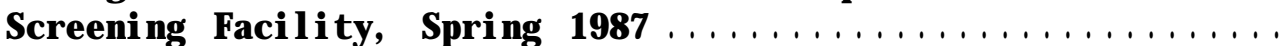

8. 21 Percentage of Steel head Uncorbyncbus mykiSin ol ts Descal ed Before Bei ng Used in Tests at Whato Canal Fi sh Screeni ng

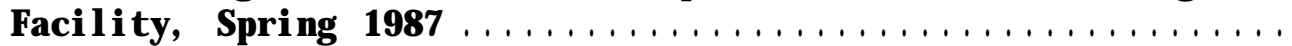

8. 22 Percentage of Spri ng Chi nook Sal mon Oncorhynchus tstanytscha Snol ts Descal ed Bef ore Being Used in Tests at Whato Canal Fi sh Screeni ng Facility, Spring $1987, \ldots, \ldots, \ldots, \ldots, \ldots$

8. 23 Percentage of Steel head Uncorbyncbus mykiss Snol ts Descal ed or Killed in Each Test at Whato Canal Fi sh Screeni ng Facility, Spring 1987

8. 24 Percentage of Spring Chi nook Sal non Utcorbyndas tshanytscha Snol ts Descal ed or Ki I ed i n Each Test at Wato Canal Fi sh

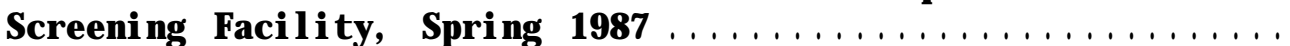

B.25 Scal e Loss for Hatchery-Rel eased and Nati ve Sal moni ds During Tests at Ri chl and Canal Fi sh Screeni ng Facility.

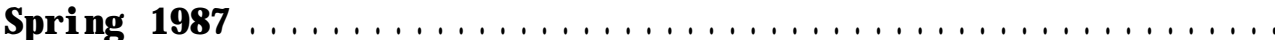

8. 26 Scal e Loss for Hatchery-Rel eased and Nati ve Sal noni ds Capt ured During Tests at the Whato Canal Fi sh Screeni ng

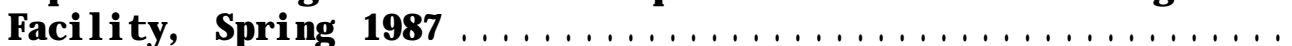

B.27 Percentage of Test Fi sh Descal ed or Killed During Pi pe Tests at Wato Canal Fi sh Screening Facility, Spring 1987

8. 28 Esti mated Ti ne to Capt ure $50 \%$ and $95 \%$ of the Test Fi sh Rel eased at Whato Canal Fi sh Screeni ng Facility. Spring 1987

8. 29 Capt ure Data for Fal I Chi nook Sal mon Utcorbyndas tshanytscha Fry Rel eased at Ri chl and Canal Fi sh Screeni ng Faci l ity,

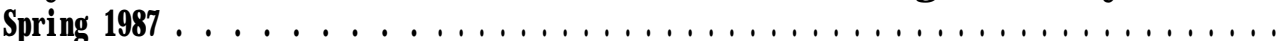


8. 30 Capt ure Effi ci enci es of the I ncl i ned PI ane and Nets and Retention Efficiency of the Fyke Nets Used in Screen Integrity Tests at Whato Canal Fi sh Screening Facility.

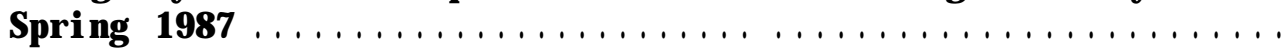

8. 31 Capt ure Data for Fal I Chi nook Sal mon Oncorhynchus tshantsda Fry Rel eased During Screen Integrity Tests at Whato Canal Fi sh Screeni ng Facility, Spring $1987 \ldots \ldots \ldots \ldots \ldots \ldots \ldots \ldots \ldots \ldots \ldots$

8. 32 Esti mated Ti me to Capt ure $50 \%$ and $95 \%$ of Fal I Chi nook Sal non Oncorhynchus tshaytsch Fay Rel eased i n Screen Integrity Tests at Whato Canal Fi sh Screeni ng Facility.

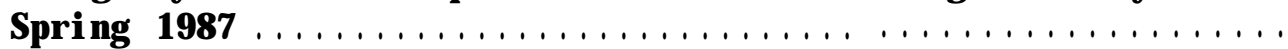

6. 33 Percentage of Steel head Uncorbync myki ss Snol ts Descal ed or Kiled in Tests of the I ncli ned Pl ane at the Toppenish Creek Canal Fi sh Screeni ng Facility, Spring 1988...........

B. 34 Percentage of St eel head Uncorbyncbumyki s s Snol ts Descal ed Bef ore Bei ng Used in Tests at the Toppeni sh Creek Canal Fi sh Screeni ng Facility, Spri ng 1988.......................

8. 35 Descal i ng and Mrtal ity Data from Rel ease and Capt ure Tests with Steel head Uncorbyncbus mykis Snolts at the Toppenish Creek Fi sh Screeni ng Facility, Spring 1988..............

6. 36 Est i nat ed Ti me to Capt ure $50 \%$ of Steel head Uhcorbyndas nykis Snol ts Rel eased in Descal ing Tests at Toppeni sh Creek Fi sh Screeni ng Faci I ity, Spri ng 1988...............

8. 37 Est i mated Ti me to Capt ure $50 \%$ of Rai nbow Trout Uhcorbyndas mykiss Fry Rel eased in Screen Integrity Tests at Toppeni sh Creek Fi sh Screeni ng Facility, Spring 1988..............

8. 38 Percentage of Steel head Utoorbyndas mykis Snolsts Descal ed In Pi pe Tests at the Toppeni sh Creek Fi sh Screening Facility,

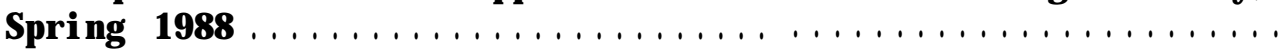

8. 39 Capt ure Dat a for Rai nbow Tr out Utcorbyndas nykis Fry s Rel eased During Screen Integrity Tests at the Toppeni sh Creek Fi sh Screeni ng Facility. Spring 1988..............

8. 40 Capt ure Effici ency of the I ncl i ned PI ane and Fyke Nets Used During Screen Integrity Tests at the Toppeni sh Creek Fi sh

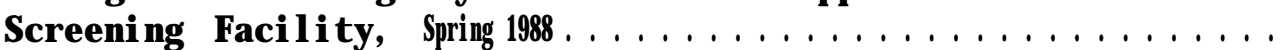


6. 41 Esti mated Ti ne to Capt ure $50 \%$ of Fal I Chi nook Sal non Uncorbyndas tshanytsch Fry aRel eased in Screen I nt egrity

Tests at the Wapato Fi sh Screening Facility. Spring 1988.....

8. 30

8. 42 Capt ure Data for Spring Chi nook Sal mon Uncorbyncbus tshanyt scha Fry Rel eased During Screen Integrity Tests at the Whato Canal Fi sh Screeni ng Faci I ity, Spri ng 1988. . . . . . . . . . . . . . . .

8. 43 Capt ure Effi ci ency of the I ncl i ned PI ane and Nets and Retenti on Effici ency for Fyke Nets Used During Screen Integrity Tests at the Whato Canal Fi sh Screening

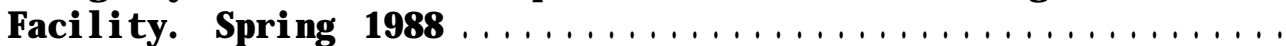

B. 44 Capt ure Data from Fyke Nets Behi nd Sel ected Screens at the Whato Canal Fi sh Screening Facility After the Rel ease of Yaki ma I ndi an Nati on Fal I Chi nook Sal non Uncorbyncbus tshanytsch faom Net Pens in the Whato Screen Forebay. Spring 1988

8. 45 Esti mated Ti me to Capt ure $50 \%$ of Fal I Chi nook Sal mon Uncorbyncbus tshawytsch Fry aRel eased in Screen I ntegrity Tests at the Sunnysi de Fi sh Screeni ng Facility, Spring 1988. .

8. 46 Capt ure Data for Fal I Chi nook Sal mon Uncorbyncbus t shawyt scha Fry Rel eased During Screen I ntegrity Tests at the Sunnysi de Fi sh Screeni ng Facility. Spring 1988.................

8. 47 Capt ure Effici ency of the I ncl i ned PI ane and Fyke Nets Used During Screen Integrity Tests at the Sunnysi de Canal Fi sh Screeni ng Facility, Spring $1988 \ldots . . \ldots$. . . . . . . . . . . . . . . . .

B. 48 Capture Data From Fyke Nets Behi nd Sel ected Screens at the Sunnysi de Canal Fi sh Screening Facility After the Rel ease of Yaki ma I ndi an Nati on Fal I Chi nook Sal mon Uncorbyncbus tshawytsch Fi ngerlings from the Whato Screens Forebay,

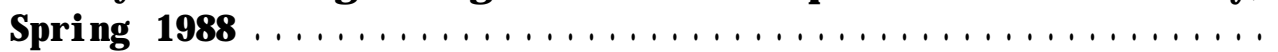

8. 49 Descal ing and Mrtal ity Data from Rel ease and Capt ure Tests with Steel head Uncorbyncbus myki ss and Spring Chi nook Sal non o.tshawytschaSnol ts at the Westsi de Ditch Fi sh

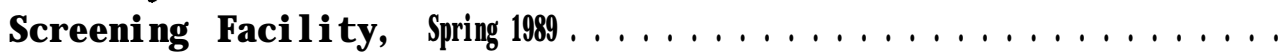

B. 50 Esti mated Ti ne to Capt ure $50 \%$ of Steel head Uncorbyncbus myki ss and Spri ng Chi nook Sal mon 0 . tstanytsch Saol ts Rel eased in Descal ing Tests at Wéstsi de Di tch Fi sh Screeni ng

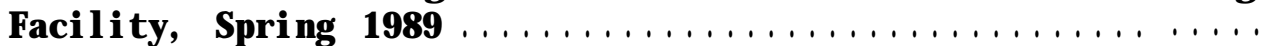


6. 51 Percentage of Spring Chi nook Sal mon Oncorhynchus tshawyt scha Smol ts Descal ed i n Pi pe Tests at the Wapato Canal Fish

Screening Facility, Spring $1989 \ldots \ldots \ldots \ldots \ldots . \ldots \ldots$

8. 52 Capt ure Data for Rai nbow Trout Oncorhynchus myki ss Fry Rel eased During Screen I ntegrity Tests at the Westsi de Ditch Fish

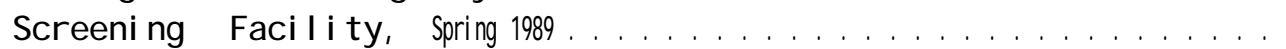

8. 53 Capt ure Data for Chi nook Sal mon Oncorhynchus tshawyt scha Fry Caught During Screen I ntegrity Tests at the Westsi de Ditch Canal Fi sh Screening Facility, Spring 1989 . . . . . . . . . . . . . . .

8. 54 Capt ure Effi ci ency of the I ncl i ned PI ane and Fyke Net S Used During Screen Integrity Tests at the Ditch Canal Fi sh Screening Facility, Spring 1989. 
The Yaki ma Ri ver Basi $n$ hi stori cal l y has supported si gni fi cant runs of sal moni ds. Duri ing the I ate 1800s. bet ween 500.000 and 600.000 adul $t$ sal mon and steel head Oncorhynchusspp. ret urned to the Yaki ma Ri ver and its tri butari es (Bureau of Recl amati on 1984). Runs of sal mon i ncl uded several races: spring, sumer, and fall chi nook sal mon 0 . tshaytscha coho sal non 0. kisutch. sockeye sal mon 0 . nerka and st eel head 0 . mykiss.

Sone of the runs now are exti nct or near exti ncti on. Spawni ng escapenent averaged about 2000 sal noni ds in the earl y 1980s (Bureau of Recl anati on 1984). There is no sockeye run i $n$ the Yaki m Ri ver Basi $n$ today, and onl y 37 coho sal mon passed the Prosser Di versi on Dam i n 1983 ( Hol l owed 1984). Recent i mprovenents in ef forts to manage and enhance sal noni $d$ runs in the Yaki $m$ Ri ver i ncreased the total spawning escapenent to bet ween 5, 000 and 10,000 adul ts i $n$ the $\mathrm{m} d-1980$ s (Fast et al. 1986).

Reduced numbers of sal noni ds returning to the Yaki ma $R$ ver Basi $n$ resul $t$ from many factors. Spawning and rearing habi tat is I ess because reduced i n-stream fl ow downst ream of i rri gati on di versi on dans. I nef fecti ve fi sh passage facilities for adults and $j$ uveniles at di versi on dans cause hi gh mortal ity during migration. Addi ti onally, many Yaki ma Ri ver fi sh are killed while passing hydroel ectric dans on the mai nstem Col unbi a Ri ver.

The Paci fi c Northwest El ectri c Power PI anni ng and Conservati on Act (Publ i c Law 96-501) was passed to enabl e preparation and i mpl ement ati on of a regi onal Conservati on and El ectri c Power PI an. The Northuest Power PI anni ng Counci I admini sters the PI an, and is charged with devel oping a program to protect and enhance fi sh and wi I dl i fe popul at i ons and to mi $t$ gate adverse ef fects from devel opment, operat $i$ on, and management of hydroel ectric facilities.

The Yaki ma Ri ver Basi $n$ was sel ected as one si te for enhancenent of sal non and steel head runs. Under the PI an, the Bonnevi I I e Power Admi ni strati on (BPA) and the Bureau of Recl anati on (BR) are funding the construction of fish passage and protection facilities at i rrigation and hydroel ectric di versi ons i n the Yaki na Ri ver Basi n (Fi gure 1). BPA is al so provi di ng f unds to the Yaki ma I ndi an Nati on to i ncrease production of spri ng chi nook sal mon i n the Yaki ma Ri ver Basi $n$.

The Westsi de Di tch and Wapato Canal Fi sh Screeni ng Faci I iti es (Westsi de and Whato Screens) are part of the passage and protection facilities being constructed i $n$ the Yaki ma Ri ver Basi $n$ by BPA and BR. Construction of the What o and Westsi de Screens was compl et ed in 1985 and 1989. respecti vel y. BPA asked the Pacific Northwest Laboratory (PN) to eval uate the effectiveness of these di version facilities in returning to the river fish that had entered the canal s. 
Thi s report covers work by PNL fi sheries staff at the Westsi de and Whato Screens in 1989. It describes each screen facility, methods used to eval uate the effectiveness of the screens, and test results. Our findings are di scussed and compared wi th resul ts fromprevi ous tests at the Sunnysi de Screens (Nei tzel et al. 1985). at the Ri chl and and Toppeni sh/ Sat us Screens ( Nei tzel et al. 1986). at the Ri chl and and Mato Screens (Neitzel et al. 1988). and at the Toppeni sh Creek, Whato. and Sunnysi de Screens (Neitzel et al. 1990). The report i ncl udes t wo appendices. Appendi $x$ A is a descripti on of the vork $\mathrm{pl}$ an prepared to gui de the eval uati ons and to associ ate specific objectives wi th the methods used during the eval uati ons. Appendi x B I i sts tables of the data col l ected at the Sunnysi de Screens in 1985. the Ri chl and and Toppeni sh/ Sat us Screens in 1986. the Ri chl and and Mato Screens in 1987. the Whato. Sunnysi de and Toppeni sh Creek screens in 1988. and the Westsi de and Wato Screens in 1989. 


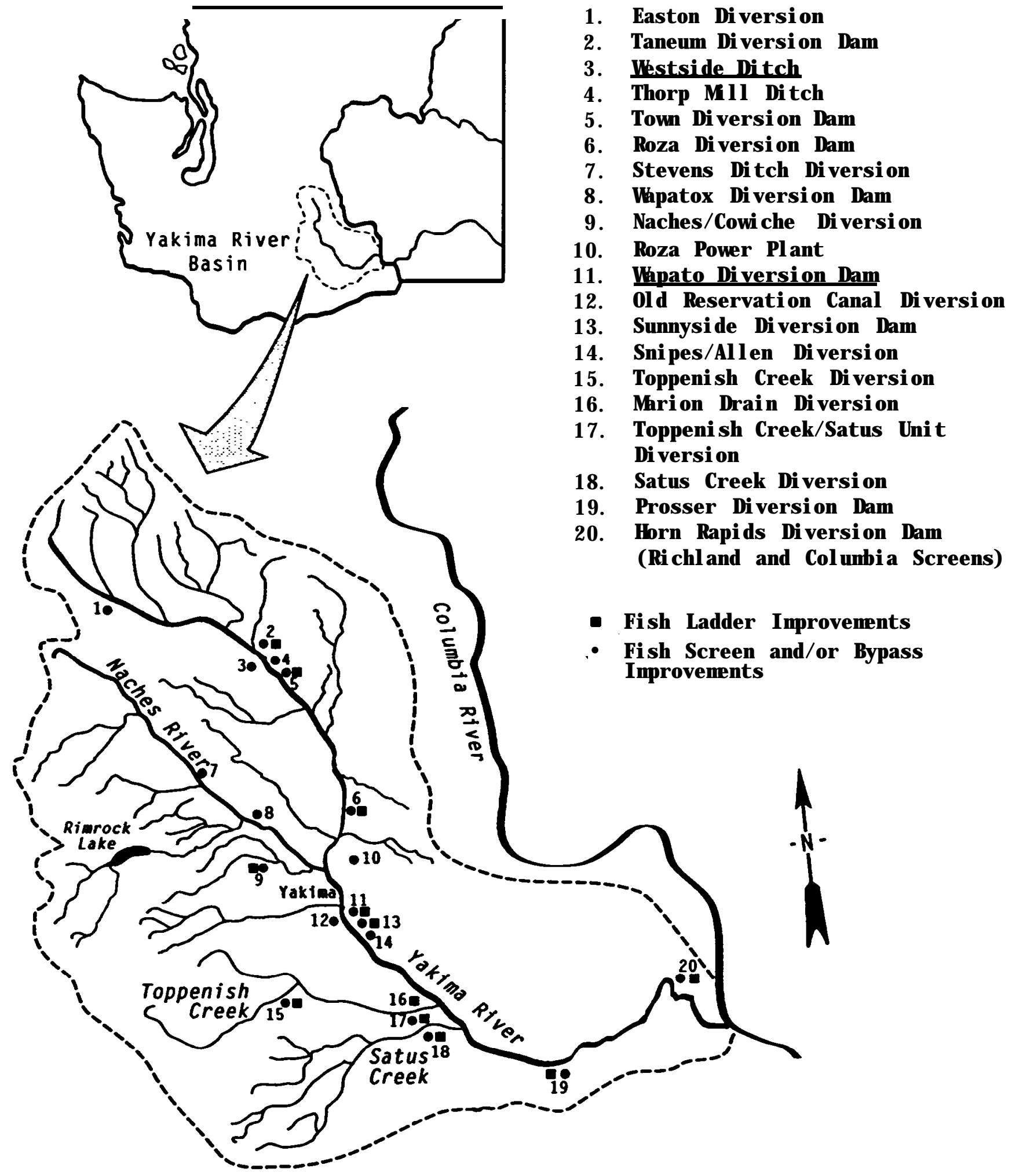

FIGURE. Yaki na Ri ver Basi n, I ncl udi ng Locati ons of the Uestsi de Di tch and Whato Canal Fish Screening Facilities and Other Fi sh Protection and Passage Facilitiles 
Duri ng 1989, st udi es were conducted at the Whato and Westsi de Ditch screening facilities. Tests were conducted on the fish return pi pe at the Whpato Screens. The st udy area for the Westsi de Ditch Screens i ncl uded the canal upstream of the screens. the screens forebay. and the canal behi nd the screens. Specific conditions tested during the eval uations are reported in the Results and Di scussi on sections.

\section{VESTSI DF DITCH CANAL}

The Westsi de Ditch Di versi on i s l ocated on the Yaki ma Ri ver at ri ver $\mathbf{k m}$ 267. 4 [river mile (RM 166. 21, near Thorpe, Whishington. Witer is di verted from the Yaki ma Ri ver i nto the Westsi de Ditch Canal. The carrying capacity of the canal is about $2.8 \mathrm{~m}^{3} / \mathrm{s}$ [100 cubi c feet per second (cfs)]. Canal fl ow varies from 0.6 to $2.8 \mathrm{~m} / \mathrm{s}$ ( 20 to $100 \mathrm{cfs}$ ) and is regul ated at the canal head gates I ocated about $0.5 \mathrm{~km}$ upstream of the West si de Di tch Screens. The screening facility (Fi gures 2 and 3 ) di verts fish that have entered the canal and di rects them back to the Yaki mi Rer. Trash racks

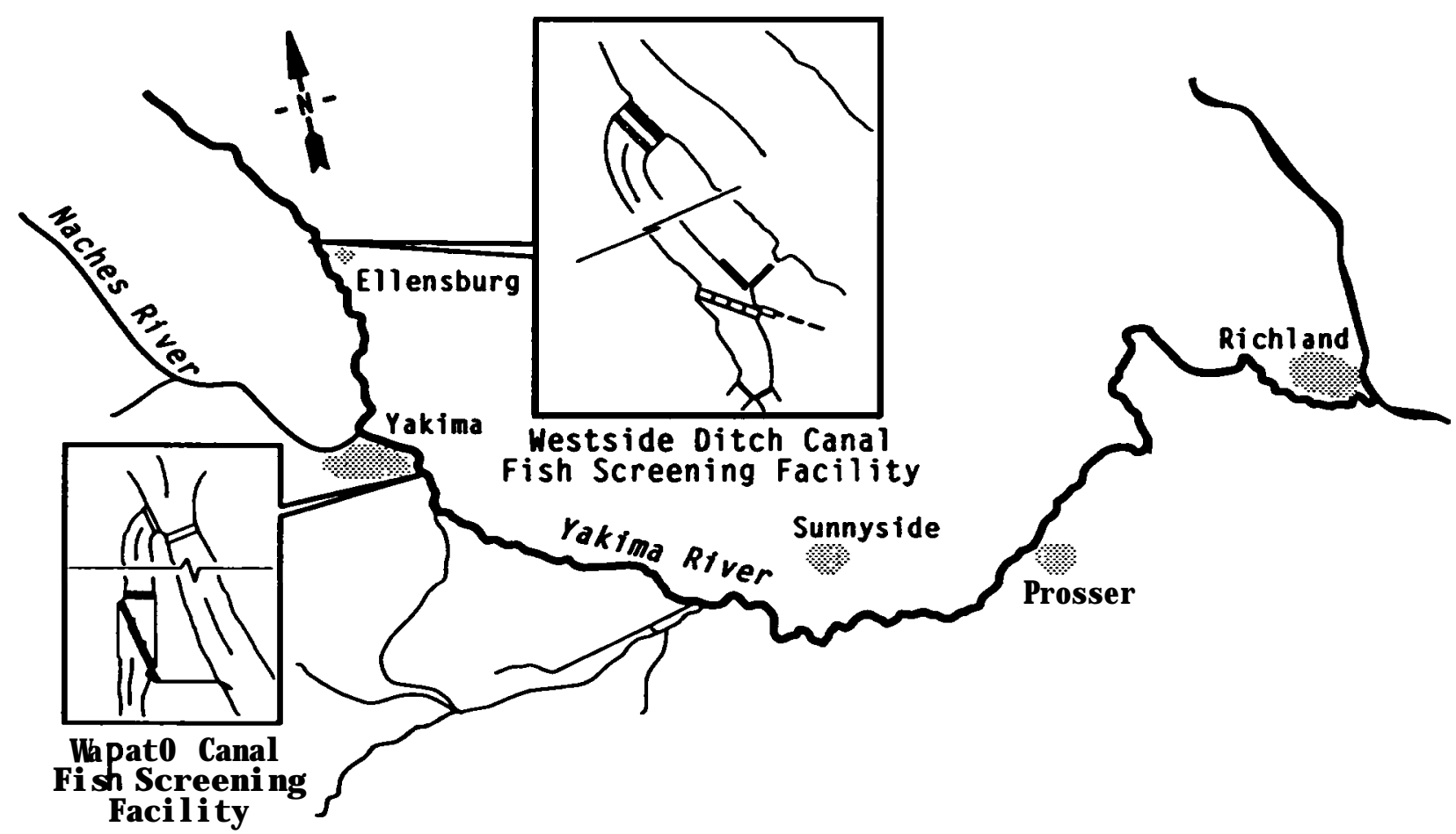

FGRE 2 Yaki ma Ri ver Basi n Showing Locati on of the Wapato Canal Fi sh Screening Facility and the Westsi de Ditch Canal Fi sh Screening Facil ity 


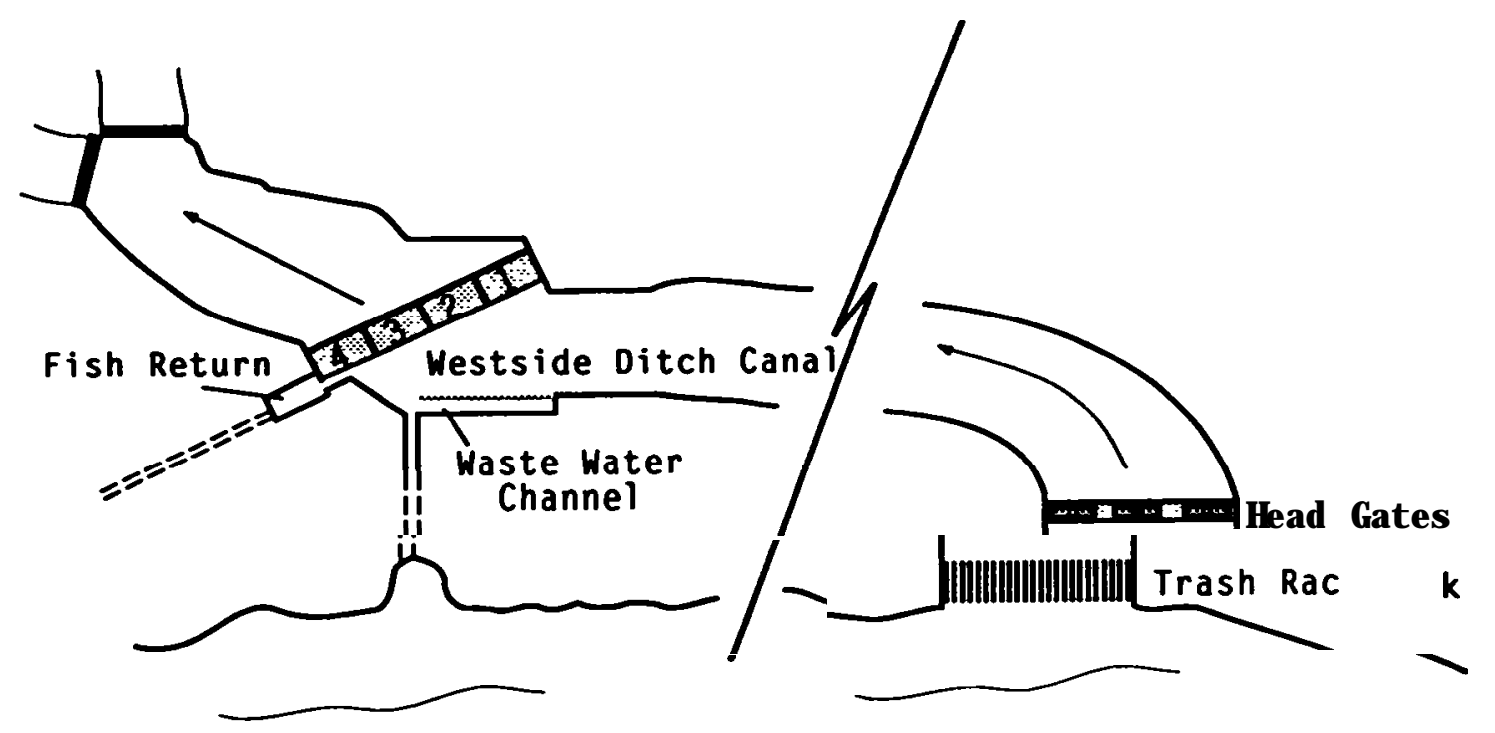

Yaki ma Bi ver

FlGRF 3. Fl ow Control Structure and Fi sh Bypass System in the Westsi de Ditch Canal Fi sh Screeni ng Facility

l ocated in front of the head gates "filter" out I arge debris that could danage the screens or interfere with flow control through the screen facil ity.

The screeni ng facility (Figure 3) houses four rotary drumscreens with axes paral I el to the I ength of the structure. Each screen is about $3.7 \mathrm{~m}$ (12 ft) I ong and $1.8 \mathrm{~m}(6 \mathrm{ft})$ i $\mathrm{n}$ di ameter. Screen mesh openi ngs are $3.2 \mathrm{~mm}$ ( $/ 8 \mathrm{i} \mathrm{n}$.). Whter depth at the screens is mai ntai ned at about $1.6 \mathrm{~m}(5 \mathrm{ft})$. The fi sh bypass is l ocated in the fl ow control struct ure at the downstream end of the screening facility. Wter and fish diverted past the front of the screens pass through the fish bypass sl ot and out the fish ret urn pi pe. Fl ow through the fish return is $0.6 \mathrm{~m} 3 / \mathrm{s}$ ( $20 \mathrm{cfs}$ ). A waste water channel i s instal led al ong the forebay wal I opposi te the drumscreens to prevent fl ooding and canal bank erosi on. Nb water fl ous out the waste water channel at normal canal for ebay I evel.

The rotary screens are i nstal led at an angle of $26^{\circ}$ to canal flow Thi s ori ent ati on is desi gned to provi de a sweepi ng-vel oci ty-to-approach- vel oci ty ratio equal to or exceedi ng 2: I (Easterbrooks 1984). The naxi mum al I oubbl e approach vel ocity is $0.15 \mathrm{~m} / \mathrm{s}$ ( $0.5 \mathrm{fps})$. Screen ori ent ati on and fl ow vel ocity differential hel $p$ di rect fish to the fish return pi pe and back to the river. 


\section{HAPATO CANAL}

The Whpato Di versi on (Fi gure 2) is l ocated at ri ver $\mathrm{km} 172$ (RM 106. 7) on the Yaki m Ri ver. The di versi on di rects water from the Yaki ma Ri ver i nto the Mhpato Canal. Canal operati on begi ns in early Merch and conti nues through the i rrigation season, usually until mid-October. Canal capacity is about $57 \mathrm{~m}^{3} / \mathrm{s}(2000 \mathrm{cfs})$.

The Whato Canal Fi sh Screeni ng Faci Iity (Whpato Screens) is I ocated about $1 \mathrm{~km}$ downstream of the head gates of the Whpato Canal. The screeni ng facility (Figure 4) di verts fish entering the canal and di rects them back to the Yaki na Ri ver.

The trash racks from the ol d screening facility. i medi atel y upstream of the new Whato Screens, are used to "filter" out debris entering the canal. The screeni ng facility houses $\mathbf{1 5}$ rotary drum screens (Figure 4) wi th axes parallel to the length of the structure. Each screen is about $7.3 \mathrm{~m}$ (24 ft) l ong and $4.6 \mathrm{~m}(15 \mathrm{ft}$ ) in dianeter. Witer depth at the screens varies with canal flowe however, the depth across the face of the screens at ful I canal level is normally about $3.7 \mathrm{~m}(12 \mathrm{ft})$.

The fl ow control structure and the separati on chanber ( Fi gure 4) are l ocated at the dounstreamend of the screen facility. Tuo fi sh bypass pi pes and the terminal bypass, each with a fl ow of about $1.4 \mathrm{~m}^{3} / \mathrm{s}$ (50 cfs). feed into the separati on chanber. During normal operati on, about $4.2 \mathrm{~m}^{3 / \mathrm{s}}$ (150 cfs) of water enter the separati on chanber. About $0.9 \mathrm{~m} 3 / \mathrm{s}$ (30 cf s) of water and al I fish that are di verted in front of the screens pass through the fl ow control structure and out the fish return pi pe. Tho bypass water ret urn pumps, each with a pumping capaci ty of $1.4 \mathrm{~m} 3 / \mathrm{s}$ ( $50 \mathrm{cfs}$ ), are l ocated behi nd travel ing screens near the terminus of the separati on chanber. The travel ing screens are equi pped with screen washers to prevent fish and debris from being entrai ned in the pumpback system

The pumpback system is not used during normal operati on. Adequate f I ous are nai ntai ned in the fi sh bypass by di schargi $\mathrm{ng} 3.4 \mathrm{~m}^{3} / \mathrm{s}$ (120 cfs) of water back to the Yaki m Ri ver over adj ustable wei rs in the pump basi $n$. When the pumps are operating, fl ow over the weirs is reduced. Thus, bypass fl ous are achi eved by adj usting wei rs in each fi sh bypass (Gates 1, 2. and 3). the fi sh return (Gate 4). and the two weirs behi nd the punp intakes (Gates 5 and 6). 


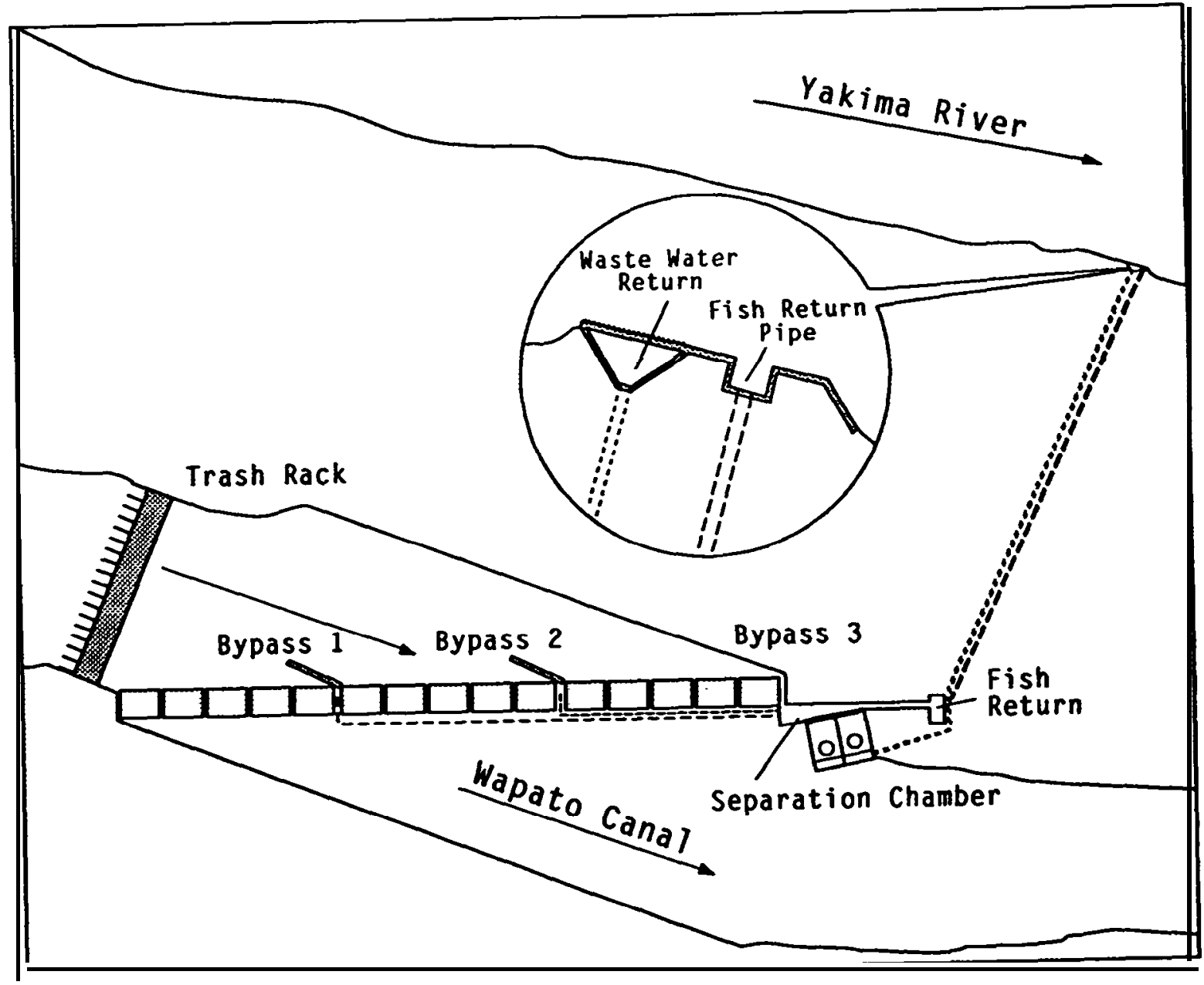

FI GRE 4. FI ow Control Structure and Fi sh Bypass System i n the Whpato Canal Fi sh Screening Facility 
Two types of tests were conducted in 1989: descal ing (Phase II) tests and screen integrity (Phase IV) tests. In Phase Ilb tests at the Whato Screens, fish were rel eased at the head of the fish ret urn pi pe and captured at the terminus of the pi pe. In Phase Ila tests at the Westsi de Ditch, fi sh were rel eased in the canal upstream of the screening facility and capt ured as they entered the fish return. Some test fish were hel d for post-test observation. Nati ve sal moni ds enteri ng the Westsi de Di tch Canal uere monitored during rel ease/capture tests. In Phase IV tests at the Westsi de Ditch Canal, fi sh were rel eased both in front of and behi nd the screens and were capt ured as they appeared in the pri mary fish return or i $n$ fyke nets mounted behi nd the drum screens.

\section{IEST FISH}

The speci es of $f i$ sh sel ected for tests were recommended by $f i$ sheri es bi ol ogi sts from the Wishi ngt on State Department of Fi sheri es ( VDF). U.S. Fi sh and Wild i fe Servi ce (USFWS). and the Yaki ma I ndi an Nati on (YIN). The speci es vere sel ected based on the potenti al i mpact of an i rri gation di versi on on specifi c sal moni d popul ati ons I i kel y to encount er each screening facility during the rearing and outmigration period. Therefore, the sel ecti on was dependent on the speci es, race, and si ze of sal moni ds occurring in the Yaki na Ri ver drai nage upstream of each di version.

Spri ng chi nook sal mon snol ts were used in Phase IIb tests at the Whato Screens. The pi pe tests repeated previ ous nork conducted at the Whato Screens ( Nei tzel et al .. 1988). Spri ng chi nook sal mon, resi dent rai nbow trout, and possi bl y steel head utilize the Yaki ma ri ver upstream of the Westsi de Di tch di versi on. Spri ng chi nook sal mon and st eel head snol ts were sel ected for Phase Ila tests and rai nbow trout fry $(<50 \mathrm{~mm})$ were used i $\mathrm{n}$ Phase IV tests at the Westsi de Ditch Screens.

\section{Steel head}

J uveni I e steel head were obtai ned from the Whshi ngt on Department of Vil dl i fe ( VoW Yaki ma Trout Hatchery in Yaki ma. Wishi ngt on. The steel head were progeny of native steel head captured at the Prosser fish trap on the Yaki ma Ri ver. The fish were transported to PN in Novenber. 1988, and were reared throughout the wi nter in a mixture of anbi ent Col unbi a Ri ver water and wel I nater. Fi sh were branded and accl i mated to temperat ures expected at the Westsi de Ditch Screens at I east 1 week bef ore rel ease. The fi sh wei ghed about $22 \mathrm{fish} / \mathrm{kg}$ (10 fi sh/l b) when rel eased in out tests. 


\section{Rainbow Irout}

Rai nbow trout fry. used i n the Westsi de Ditch Screens i ntegrity tests. were obtai ned from PN brood stock spauned i n Decenber 1988. Eggs uere hatched i n verti cal fl ow i ncubat ors suppli ed wi th $10^{\circ} \mathrm{C}$ wel I water. Fry were transferred to troughs and reared at $10^{\circ} \mathrm{C}$ until testing comenced. Rai nbow trout fry used in tests at the Westsi de Ditch Screens averaged $49 \mathrm{~mm}$ fork l ength (FL) and were branded at l east one week pri or to rel ease.

\section{Chi nook Sal mon}

Yearling spring chi nook sal mon were obtai ned from the Leavenuorth Nati onal Hatchery in Leavenworth, Whshi ngt on. The fi sh were transported to PN in February 1988, and hel d i n anbi ent Col unbi a Ri ver water until used in pi pe tests at the Whato Screens. Fi sh used in Phase Ilatests at the Whstsi de Ditch Screens were branded at I east 1 week before rel ease. The fi sh wei ghed about $35 \mathrm{fi} \mathrm{sh} / \mathrm{kg}$ ( $16 \mathrm{fi} \mathrm{sh/l} \mathrm{b)} \mathrm{when} \mathrm{rel} \mathrm{eased.}$

\section{SAMPI N NG EQU PNENT}

Fi sh were capt ured wi thin the screening facility, at the terminus of the primary fish return pi pe, and in the canal behind the screens, based on the objecti ves of each test. An i ncl i ned pl ane was cust om built to fit the fi sh bypass structure at the Westsi de Ditch Screens. A fyke net was used to collect fish at the termi nus of the Whato Screens fish ret urn pi pe, and fyke nets were mounted in stopl og sl ots behi nd the rotary drumscreens to col lect fish at the Westsi de Ditch Screens. Temporary fi sh-hol ding facilities uere instal led at the Westsi de Ditch Screens to accli mate and hol d test fish.

\section{Inclined Plane}

Fi sh were capt ured by $\mathrm{pl}$ acing an i ncl i ned $\mathrm{pl}$ ane in the fi sh ret urn bet ween the I ast rotary drum screen and the head of the fi sh return pi pe. The i ncl i ned plane used at the Westsi de Ditch Screens (Figure 5) uas $2.1 \mathrm{~m}$ $(7.0 \mathrm{ft})$ I ong and $1.0 \mathrm{~m}(3.3 \mathrm{ft})$ wi de. The front $\mathrm{face}$ of the $\mathrm{pl}$ ane was hi nged so that the sl ope of the plane coul d be changed to adj ust the fl ow of water reaching the fi sh I i ve box. Sol id walls, tapering from $0.9 \mathrm{~m}$ ( $3 \mathrm{ft}$ ) at the entrance to $0.41 \mathrm{~m}(1.3 \mathrm{ft}$ ) at the Ii ve box, acted as spl ash guards to reduce fish I oss from the $\mathrm{pl}$ ane. A I i ve box $[0.38 \mathrm{~m}(1.3 \mathrm{ft})$ l ong by $1.0 \mathrm{~m}(3.3 \mathrm{ft}$ ) wi de. 1001 ( $26 \mathrm{gal}$ ) vol une] was fast ened at the end of the i ncl i ned $\mathrm{pl}$ ane. The i ncl i ned $\mathrm{pl}$ ane had an al uni num frame covered wi th a perforated al um num sheet $[0.32-\mathrm{cm}$ (I/ 8- i n. -) di ameter hol es. staggered centers. 40\% open]. Fl ow was di rected over the plane surface by i nserti ng dam boards in the upstream stopl og sl ot in the fi sh bypass sl ot. The hei ght of the dam boards rel ati ve to the water depth determined the water vol une through the fish bypass. 


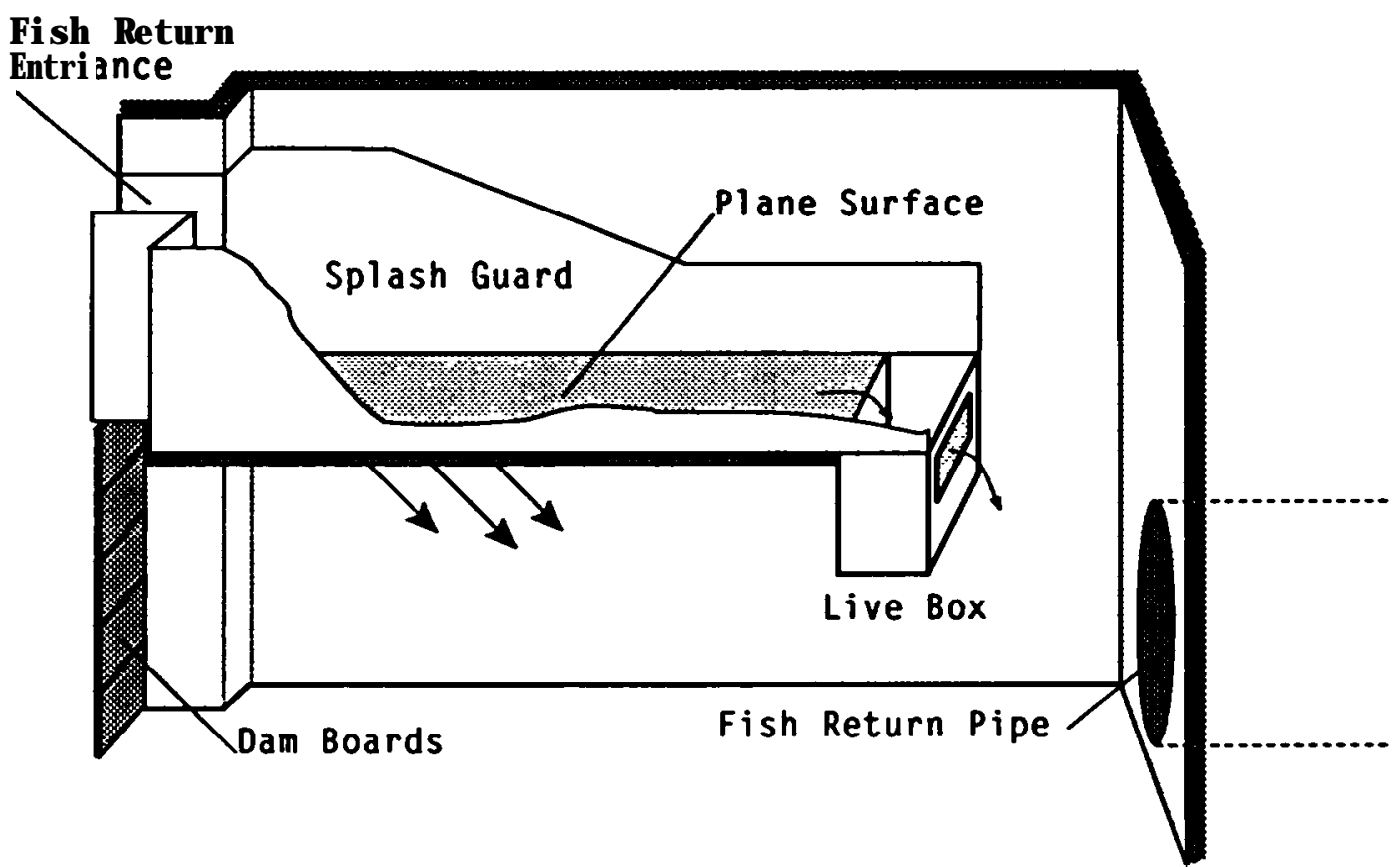

FI GRE. I ncl i ned PI ane Used at the Westsi de Di tch Canal Fi sh Screeni ng Facility, Spring 1989

\section{Eyke Nets}

The fyke net used for pi pe tests at the Whato Screens was attached to a frame that $f i t$ into sl ots in the concrete structure at the terminus of the fi sh return pi pe (Figure 6). The frane uas equi pped with an adj ustable sol id metal wing that defl ected fl ow from the waste water ret urn and the Yaki ma Ri ver around the fl ow from the fi sh ret urn pi pe. The defl ector was al so used as an anchor poi nt to prevent entangl enent of the fyke net and to ensure that fish would not be harmed when exiting the fish ret urn pi pe. The net nouth was $1.0 \mathrm{~m}(3.3 \mathrm{ft})$ wi de and $1.4 \mathrm{~m}(4.5 \mathrm{ft})$ tal $\mathrm{l}$ and tapered to a 0.5- $\mathrm{m}$ square cod end over a l ength of $4.9 \mathrm{~m}$ A hoop net $(1 \mathrm{~m}$ di ameter, $4 \mathrm{~m}$ long) was fastened to the cod end net to provi de addi ti onal hol di ng area for $f i$ sh, extendi ng the I ength of the net to about $8 \mathrm{~m}$ (25 ft). The portion of the net attached to the deflector wing was constructed of solid vi nyl sheeting to protect fish from net abrasion as they exited the fish return pi pe.

Fyke nets were used behind each of the four drum screens in integrity tests at the Wistsi de Ditch Screens. The nouths of the nets were $3.7 \mathrm{~m}(12 \mathrm{ft})$ wi de and $1.8 \mathrm{~m}(6 \mathrm{ft})$ deep. The tops of the nets were above the water surface, and the bottons of the nets settled into the mud on the canal floor. The net mouth tapered down to the 0.91- $\mathrm{m}$ (3-ft) square mouth of the cod net over a l ength of $4.6 \mathrm{~m}(15 \mathrm{ft})$. The two si des of the net were 


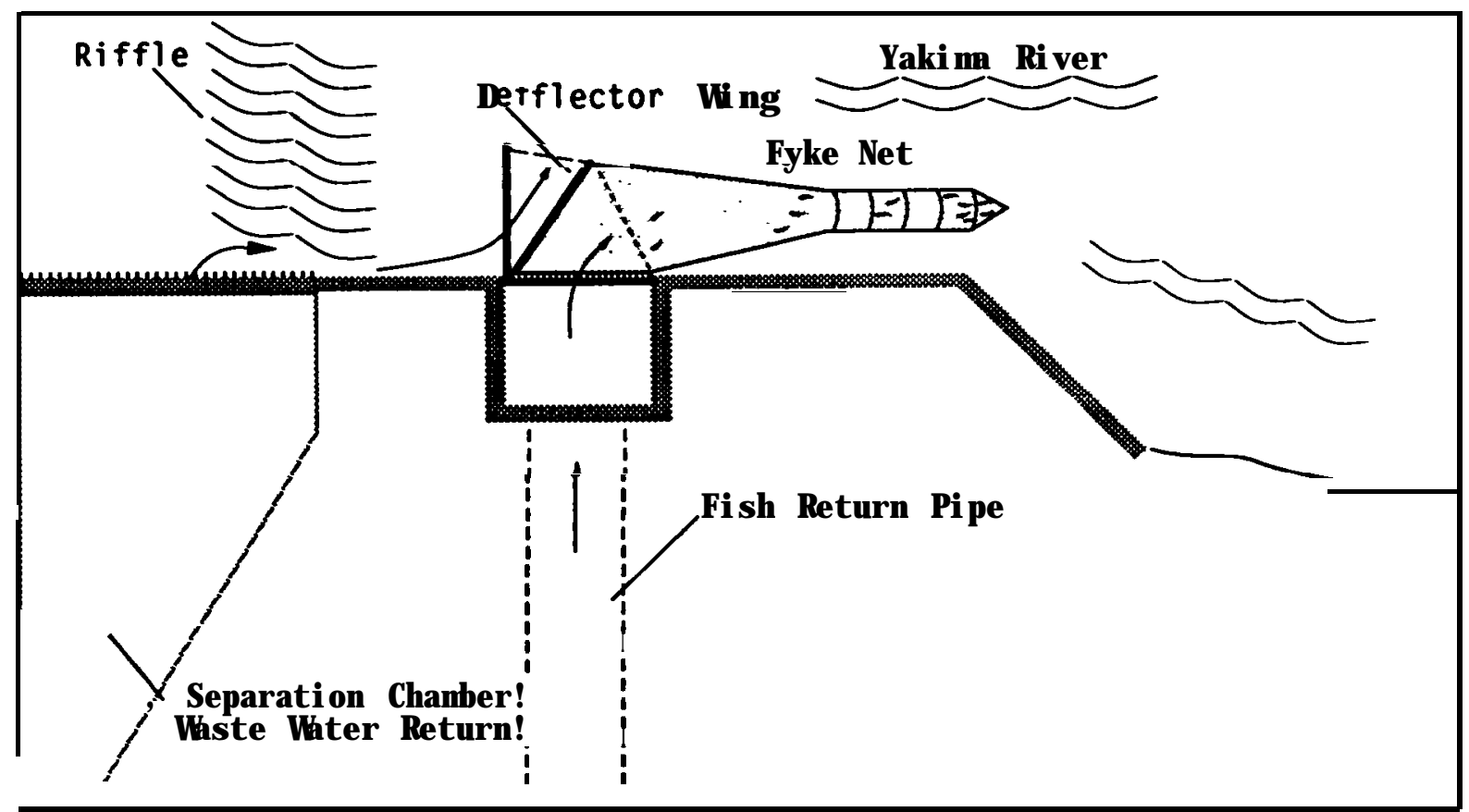

FI GRE. Fyke Net Used in Pipe Tests at the Whato Screens, Spring 1989

of different I engths so that the net would hang paral I el to canal fl ow wi thout bill owing on one si de (Fi gure 7). The cod net was $1.8 \mathrm{~m}(6 \mathrm{ft}$ ) l ong, resulting in an overal I net l ength of $6.4 \mathrm{~m}(21 \mathrm{ft})$. The end of the cod net was ti ed shut. The nets were-fi shed conti nuously during screen integrity tests, except for about $1 \mathrm{~h}$ interval s at the termination of each test, when the nets were rai sed fromthe water for fish retrieval and net cl eani ng.

\section{HOL DING FACILITIES}

Temporary facilities were instal led at the Westside Ditch Screens to hold fi sh during descal ing eval uati on and to retai $n$ sone $f i$ sh for $96 \mathrm{~h}$ after capt ure. A nobi le laboratory contai ni ng three fi bergl ass troughs [ $3 \mathrm{~m}$ (10 ft) I ong by $0.6 \mathrm{~m}(1.8 \mathrm{ft})$ wide, $0.3 \mathrm{~m}(0.8 \mathrm{ft})$ deep, and 5401 (140 gal) in vol une], and two fi bergl ass ci rcul ar tanks $\mathrm{Cl} .22 \mathrm{~m}(4 \mathrm{ft})$ i $\mathrm{n}$ di aneter by $0.6 \mathrm{~m}(2 \mathrm{ft})$ deep] was noved onto the si te. Al tanks were supplied with canal water that was pumped from behi nd the screens. The nobile lab was equi pped wi th fl uorescent I i ght ing so that fish capt ured during both the day and ni ght could be eval uated for descal ing under si milar li ght condi ti ons. 


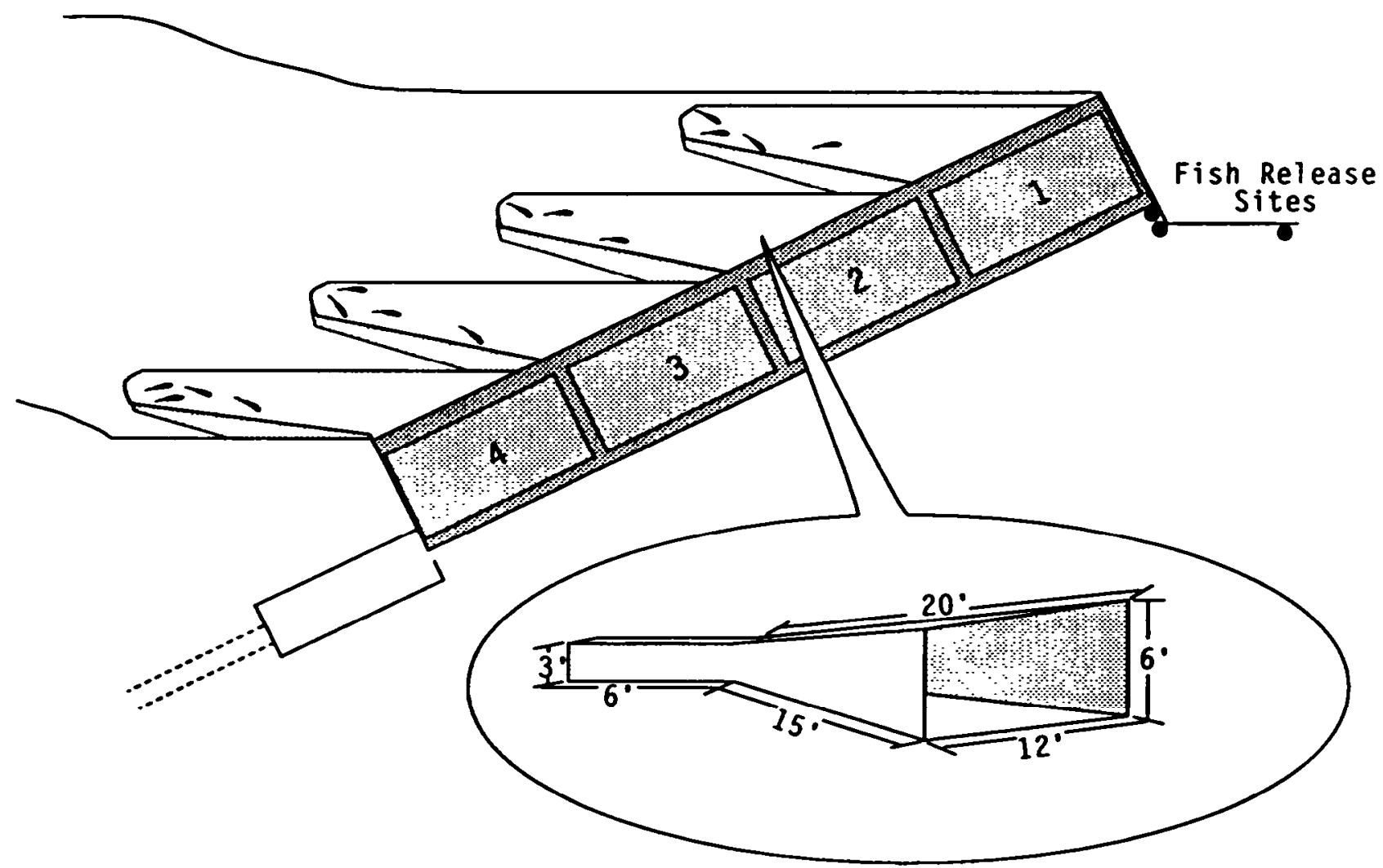

EIGURE 7. Fyke Nets Used in Integrity Tests at the Uestsi de Ditch Screens, Spring 1989

\section{DESCALINGEVALUATI ON}

An eval uati on system devel oped by the U.S. Army Corps of Engi neers (Basham et al. 1982) uas used to nonitor the condition of $f i s h$ at both sites. Eval uati on cri teri a i ncl uded nodi fi cati ons est abl i shed i $n 1985$ (Nei tzel et al. 1985). Basel i ne descal ing condi ti on was determined by randonl y sampl ing groups of test fish bef ore thei $r$ rel ease. Descaling uas eval uated in each of 10 areas, 5 on each si de of the fish. When $40 \%$ or more scal e l oss was observed in any 2 areas on one si de of a $f i s h$ the $f i$ sh was cl assi fi ed as descal ed.

\section{TEST PROCEDURE}

Pi pe tests at the Uapato Screens were accompli shed by rel easing spring chi nook sal mon snol ts at the head of the fi sh return pi pe and capt uring them in a fyke net nounted on the terminus of the fish return pi pe. The tests were conducted duri ng the dayt i me when movenent of nati ve sal moni ds nould not interfere with collection. 
Descal ing eval uations at the Uestsi de Ditch Screens were made by i nt roduci ng branded groups of steel head and spring chi nook sal non smol ts into the canal upstream of the screening facility and capt uring the fish when they appeared on the i ncl i ned pl ane in the pri mary fi sh ret urn (Phase I la, Appendi x A). Tests were conducted during the I ast week in Apri I. Fl ows were set and mai nt ai ned near naxi mum canal fl ow Nati ve sal moni d popul ations were nonitored during tests at the Uestside Ditch Screens (Phase IVa. Appendi x A). Screen integrity tests were conducted at the Uestsi de Ditch Screens by rel easi ng branded groups of rai nbow trout in front of and behi nd the rotary screens (Phase I $\mathrm{V}$, Appendi $x$ A). Fi sh were collected as they appeared either on the inclined plane in the fish ret urn or in fyke nets pl aced in the canal behi nd the screens.

\section{Iest Stock Identification}

Test fi sh were col d branded to i denti fy speci fic test groups. St eel head and spring chi nook sal mon were marked ei ther in the right anteri or or the right dorsal. The brands were appl i ed at l east 1 week bef ore rel ease. The brands used in our studies, approved by the National Mari ne Fi sheries Servi ce (NMFS), were di sti ngui shabl e from al I ot her brands used in the Col unbi a Ri ver Basi $n$. Spring chi nook sal mon used in pi pe tests at the Uapato Screens were not narked.

\section{Fish Transport and Rel ease}

Test $f i$ sh were transported at accl i mati on temperat ure i $n$ an i nsul at ed $t$ ank [400 1 ( 125 gal ) i n vol une] suppl i ed with oxygen. Transit ti mes from PNL to the Uestside Ditch and Uapato screens were $2.5 \mathrm{~h}$ and $1.3 \mathrm{~h}$.

respecti vel y. Loading densiti es di d not exceed $120 \mathrm{~g}$ of $\mathrm{fi}$ sh/l. Whter temperature in the transporter changed I ess than $1^{\circ} \mathrm{C}$ during transit. Test fi sh were netted from the transporter and placed i $n$ hol di ng tanks at the facility for accli mation bef ore rel ease into the canal for tests at the Uestsi de Ditch Screens. Test fish used in pi pe tests at the Uapato Screens were netted from the transport tank i nto buckets and poured di rectly i nto the head of the fish return pi pe. No losses were attributable to transporting stress.

\section{ish Rel ease Locations}

Test fi sh for descaling eval uati on at the Uestsi de Di th Screens vere rel eased from the north bank of the canal about $150 \mathrm{~m}$ upstream of the screening facility. Rai nbow trout used in Phase IV tests at the Uestsi de Ditch Screens were rel eased j ust upstream of the first rotary screen near the structure wal I (Figure 7) and uni formy across the mouth of the fyke nets positioned on the downstream si de of the rotary screens. Fi sh were al so rel eased at the entrance to to the inclined plane to test gear efficiency and effect. In Phase Ilb tests at the Uapato Screens. fi sh were rel eased at the head of the fish return pi pe, where the water falls over 
Gate 4 in the termi nus of the fish return sl ot. and in the mouth of the fyke net mounted at the terminus of the fish return pi pe.

\section{Release Controls}

The condi ti on of test fish at the ti me of rel ease (basel i ne condi ti on) for fi sh used in Phase Ilbtests at the Uapato Screens and in Phase Ila tests at the Uestsi de Di tch Screens was esti mated by sampl ing each group of test fi sh bef ore rel ease. Basel i ne condi ti on eval uati ons were conduct ed under nat ural I i ght condi ti ons at the Uapato Screens, and i nsi de the nobi I e I aboratory under artificial Iight for Phase Ilatests at the Uestside Ditch Screens. For Phase IIb tests at the Uapato Screens, 110 spring chi nook sal non snol ts vere eval uat ed for basel i ne condi ti on, 105 fi sh were eval uated to neasure descal ing caused by col l ecti on gear, and $\mathbf{1 5 0}$ were rel eased at the head of the fish return pi pe. For Phase II tests at the Uestsi de Di tch Screens. 100 steel head and 100 spring chi nook sal mon smol ts were sampl ed for basel i ne condition. 60 steel head and 70 spring chi nook sal mon were eval uated to measure descal ing caused by col l ecti on gear, and 750 steel head and 755 spring chi nook sal non were rel eased i $n$ front of the screens.

\section{ish Caot ure and Eval uati on}

Spri ng chi nook sal mon used in Phase Ilb tests were recovered from the fyke net at the mouth of the Uapato Screens fi sh ret urn $15 \mathrm{~min}$ af ter thei $r$ rel ease at the head of the fish return pi pe. The cod end of the net was renoved from the water, and the fish were transferred to a bucket and anesthetized in Mb-222. The fi sh were exami ned to determi ne scal e I oss, then $\mathrm{pl}$ aced i $\mathrm{n}$ anot her bucket to recover bef ore bei ng rel eased i nto the Yaki na Ri ver.

Fi sh capt ured during Phase Ila tests at the Uestsi de Ditch Screens were netted from the I i ve box of the i ncl i ned $\mathrm{pl}$ ane and $\mathrm{pl}$ aced i $\mathrm{n}$ a hol di ng tank bef ore eval uation. Eval uati ons were made at hal $f$-hour i nterval s. The fi sh were anest heti zed i n MD-222, exami ned to determi ne the extent of scal e I oss. and returned to another hol di ng tank. After fi sh recovered from the anesthetic. they were rel eased into the fish return pi pe. About 100 steel head and 200 spring chi nook sal mon snol ts were hel d for $96 \mathrm{~h}$ to nonit or del ayed nortal ity.

The purpose of Phase I Vb tests was to determi ne the effecti veness of screening facilities in preventing fish fromentering the canal behi nd the screens. and to monit or the rate at which fish noved through the fish bypass. Thus, fi sh capt ured i $n$ Phase I Vb tests were not eval uated for descaling. Fish were identified by brand group and enumerated as they appeared on the i ncli ned $\mathrm{pl}$ ane i $\mathrm{n}$ the fish return. The brands identified when and where the fish were released within the screening facility. 
The i ncl i ned pl ane uas fi shed conti nuousl y during our tests at the Uestsi de Ditch Screens. Groups of $\mathrm{fi}$ sh for Phase I Vb tests were rel eased in front of and behind the screens during the morning. The fyke nets were fished cont i nuousl y for about $23 \mathrm{~h}$ fol l owi ng the rel ease of test fi sh and then were raised for about $1 \mathrm{~h}$ to retrieve fish and to clean the nets. The nets were repositioned bef ore the initiation of each test.

\section{STATISTICALANA1_YSIS}

Esti mates are gi ven for the percent of fish killed or descal ed during the screen eval uations. The anount of ti me for test fi sh to move from thei $r$ rel ease poi nt to the i ncl i ned $\mathrm{pl}$ ane is esti mated from the hours requi red to capt ure $50 \%$ of a test group. The capt ure ef $\mathrm{i}$ ci ency of the i ncl i ned pl ane and the fyke nets used during screen i ntegrity tests are esti nated usi ng the number of fish captured during a test. The efficiency data are used to esti mate the effici ency of the screen in preventing fish from passing from the screen for ebay to the canal dounstream of the screens.

\section{Descalina and Mrtali'tv Fsti mates}

Esti nates of the percentage of $\mathrm{fi}$ sh descal ed or ki Il ed were based on the number of test $f i$ sh caught. Descal ed fish were consi dered dead for eval uati on of the resul $t s$. The l over and upper conf $i$ dence i nterval $s$, respecti vel $y$, are esti mated as

$$
L Q-\frac{B}{B+(n-B+1) F}
$$

and

$$
U C 1-1-\frac{n-B}{n-B[n-(n-B)+H] F}
$$

where $B$ equal s the number of dead or descal ed $f i s h, n$ the number of $f i$ sh caught, and $F$ a rati $o$ of the esti mates for the mean sample vari ance and the i ndi vi dual sampl e vari ance. The est i mates were cal cul at ed from Mi $n l$ and's Tabl es ( Mi nl and et al. 1956)

Data for repl i cate tests were combi ned to obtai $n$ a nean esti nate. The esti mate assumes each fi sh behaved i ndependentl y ( $i$. e. . fi sh wi thi $n$ a test di d not behave more si milarly than fish bet ween tests and there uere no interactions among fish within a test). Al though sone interaction is expected anong $\mathrm{f} i \mathrm{sh}$, the assumpt $i$ on is necessary for the anal yt i cal net hods used. Al tests were conducted in the sane manner to reduce noni ndependent behavi or of $\mathbf{f i}$ sh.

\section{Screen Fffi ci encv Esti mates}

Three tests with four groups of fi sh were conducted at Uestsi de Ditch. Screen ef $\mathrm{i}$ ci ency esti mates were computed for each test in addi ti on to an 
overal I esti mate. Fyke nets were in pl ace behi nd each screen for each test.

Tho quanti ti es are computed to esti mate screen effici ency. They are i ncl i ned $p l$ ane ef $f i c i$ ency $\left(E F F_{i p}\right.$ ) and net capt ure ef $f i c i$ ency $\left(E F F_{n c}\right.$ ). Net retention is assumed to be equal to net effici ency at Uestside Ditch. Thus, net retention equal $s$. G ven this, the formul a for computating of screen ef $\mathrm{fici}$ ency $\left(\mathrm{EFF}_{\mathrm{SC}}\right)$ is

$$
E F F_{S C}-1-\frac{x_{n e t}}{E F F_{n C^{N}}}
$$

where Xnet equal s the number of $\mathrm{f} i \mathrm{sh}$ rel eased upstream of the screens and caught in the nets, and $\mathbf{N}$ is def $i$ ned as:

$$
N=\frac{x_{\text {net }}}{E F F_{n c}}+\frac{x_{i p}}{\text { EFFi }}
$$

where $x_{i p}$ equal $s$ the number of $f i$ sh rel eased upstream of the screens and caught in the inclined $\mathrm{pl}$ ane. $\mathrm{N}$ represents of the total number of $\mathrm{fish}$ rel eased into the section bei ng esti mated. For sone esti nates and the overal I esti mate, some fish are still not accounted for af ter the effici enci es ( $E F F_{i p}$ and $E F F_{n c}$ ) have been consi dered. To avoi d making assumpti ons about what $\mathrm{m}$ ght have happened to these, an effecti ve $\mathbf{N}$ has been computed that is smal ler than the act ual nunber rel eased. It mist be noted that $\mathbf{N}$ is not an actual accounting of al I fi sh caught i $n$ di fferent l ocati ons ( $\mathrm{i}$ ncl i ned pl ane, fyke nets. bypass), but an esti nate based on the actual numbers, adj usted by effi ci enci es for net I osses and human error.

The effici enci es per set must now be defi ned. The i nput data for each section are as were expl ai ned, combining across rel evant tests. The general forns are

$$
\text { EFFi } p=\frac{n_{i p}}{N i p} \quad \text { and } \quad \text { EFFnc }=\frac{n_{n c}}{N_{n c}}
$$

where ni $p$ is the number of $f i$ sh rel eased i $n$ the bypass and caught in the i ncl i ned $\mathrm{pl}$ ane for the secti on bei ng esti mated, $\mathrm{N} p$ is the number rel eased i $n$ the bypass, nnc the number rel eased in the net nouth and caught in the net. and Nhc the number rel eased in the net nouth.

For the overal I effici ency, it should be noted that indi vi dual test efficiencies are not si mply averaged: rather. the efficiency is computed by conbi ning al l data. Averaging the separate tests would assune equal numbers were rel eased in each test and wei ght them as such. By computing the overal I esti mates fromal I data I umped as one test, the varying $\mathbf{N}$ val ues are incorporated and differences in test size are compensated. 
The confi dence interval s were computed using the standard normal approxi mati on method (Mod et al . 1974). For a 95\% conf $i$ dence i nterval

$$
P\left[E F F_{S C}-1.96 \sqrt{\operatorname{var}\left(E F F_{S C}\right)} \leq \operatorname{true}\left[E F F_{S C}\right] \leq E F F_{,},+1.96 \sqrt{\operatorname{var}\left(E F F_{S C}\right)}\right]=0.95 .
$$

Here $E_{S F}$ i ndi cates our esti mate while true [EFF $F_{S C}$ ] indi cates the true or actual val ue of the screen efficiency. EFF the formfor its vari ance is $E_{S F}\left(1-E F F_{S C}\right) / N$. However. because we used ef $\mathrm{i}$ ci enci es (EFFi $p$, EFFnc. $E F F_{n r}$ ) in the computation of EFFsc wi th thei $r$ own i nherent errors. these errors must be propagated and i ncorporated i nto the vari ance of EFFsc. If EFFncr is defi ned to be the conbi ned catch and retai $n$ ef $i$ ci ency $\left(E F F_{n c} \times E F F_{n r}\right)$, then the vari ance of EFFsc is

$$
\operatorname{var}\left[E F F_{S C}\right]-\left(\frac{\partial E F F_{S C}}{\partial E F F_{i p}}\right)^{2} \operatorname{var}[E F F i p]+\left(\frac{\partial E F F_{S C}}{\partial x_{n e t}}\right)^{2} \operatorname{var}\left[x_{n e t}\right]
$$

where al I variables are as previ ously defi ned. This formul a is the first term of a Tayl or's seri es expansi on ( Hol man 1971). Second-order and hi gher order effects have been negl ected. The assumption is made that EFFi $p$ and Xnet are i ndependent of each other. whi ch is reasonable in this case.

The vari ances of EFFi $p$ and EFFnc were computed by assuming them to be bi nomial proporti ons and usi ng the appropri ate $\mathbf{N}$ for the section in the EFF(1-EFF)/N formula as stated previ ousl $y$. The vari able Xnet, the nunber of $\mathrm{fish}$ caught i $\mathrm{n}$ the nets that were rel eased upstream of the screens, is di st $r i$ but ed bi nomal ( $\left.N, E F F_{S C}\right)$, maki ng its vari ance equal to $N\left[E F F_{S C}\right.$ (1$\mathrm{EFF}_{\text {SC }}$ )]. 


\section{RESULTS}

Fi sh that passed through the fish return pi pe at the Uapato Screens or the fi sh bypass system at the Uestsi de Ditch Screens were not descal ed or killed. Fi sh were not "fI ushed" fromthe screen forebay at the Uestsi de Ditch Screens, but moved out of thei $r$ own vol ition. The angl ed rotary drum screen desi gn prevented most fish fromentering the canal behi nd the screens at Uapato. At Uestsi de Ditch, chi nook sal mon fry were able to pass through. over. or around the screens. Data are presented as they rel ate to the obj ecti ves of each phase out li ned i $n$ the work pl an (Appendi $x$ A). A detai l ed summary of the catch data and esti mates for percentage of test fi sh that were descal ed or ki Iled are presented i n Appendi X B.

PHASF 1 .

Phase I tests are desi gned to eval uate components wi thi $n$ the fi sh di versi on system other than the rotary drum screens. The Uestsi de Ditch Screens fi sh bypass system contai ns no structures other than the drum screens:

therefore, no Phase I tests were conducted at the Uestsi de Ditch Screens.

PHASE

Phase II tests eval uated ei ther the enti re fi sh bypass system from the trash racks through the fish return pi pe (Phase Ila) or specific components of the fish return systen (Phase IIb). We i ni ti ated our eval uati ons with Phase Ila testing at the Uestsi de Ditch Screens. We rel eased fi sh into the canal upstream of the screeni ng facility and capt ured them in the i ncl i ned pl ane before they entered the fi sh return pi pe. I n addition to col I ecti ng fi sh descal ing and nortal ity data. we determi ned how I ong rel eased fi sh remai ned upstream of or wi thi $n$ the Westsi de Di tch Screens. Phase IIa and Ilb tests were compl et ed at the Uapato Screens in 1987 ( Nei tzel et al . 1988). Phase IIb tests were repeated at the Uapato Screens in 1989.

Phase لla

Tests at the Uestsi de Ditch Screens were conducted i n I ate Apri I. Two groups of branded steel head and two groups of spring chi nook sal mon snol ts nere rel eased in the canal upstreaa of the screens forebay. One group of st eel head and one group of spring chi nook sal non ( $375 \mathrm{fi}$ sh per group) were rel eased during the morning. and two groups of fi sh ( 375 steel head and 380 spring chi nook sal mon) were rel eased in the evening. of the groups rel eased in the norni ng, 304 steel head (81. 1\%/ and 371 spri ng chi nook sal non (98.9\%) were capt ured on the i ncl i ned pl ane in the fi sh ret urn duri ng the next $96 \mathrm{~h}$. of the fi sh rel eased in the eveni ng, 321 steel head (85. $6 \%$ and 379 spring chi nook sal mon (99.7\%) were caught in the fol l owing 75 h. A total of 625 steel head and 750 spri ng chi nook sal mon were exami ned for descal i ng, and 11 steel head $(1.8 \%$ and 2 spri ng chi nook sal mon ( $0.3 \%$ were descal ed (Table 1 ). The descal ing rates of $1.8 \%$ for steel head 
and $0.3 \%$ for spri ng chi nook sal mon were wel I wi thi $n$ the $95 \%$ conf $i$ dence interval s for the condi ti on control s (Appendi x B). None of 104 steel head and 204 spring chi nook sal non hel d for 96 hr to monitor del ayed nortal ity di ed.

The dounst ream movenent of st eel head and spri ng chi nook sal mon rel eased for descal $i$ ng eval uati ons was moni tored each hal $f$-hour as the $f i$ sh appeared on our sampling plane in the fish return. The novenent rate for steel head ( Fi gure 8, Tabl e 2) i ndi cates that sal nonid snol ts are not fl ushed from the Uestsi de Ditch Screens forebay; rather, they move through the screen for ebay of thei $r$ own volition. Spring chi nook sal mon exited the screens for ebay qui ckl y ( Fi gure 9, Tabl e 2).

Phase IIb

Because test fish were more easily captured at the fl ow control structure, the potential effect of passage through the fish return pi pe was eval uated separatel y at the Uapato Canal. Because this was a test of a specific component of the fish return system test results are presented as Phase I Ib data.

Three groups of $\mathbf{5 0}$ spring chi nook sal mon were rel eased at the head of the Uapato Screens fish return pi pe. Al of the fi sh were capt ured and eval uated for descal ing, and none of the fi sh were descal ed (Table 3 ).

\section{PHASF}

Phase III tests at the Uapato Screens were compl et ed in 1987 ( Nei tzel et al. 1988) and were repeated this year. Tests at the Uestsi de Ditch Screens were conducted about 1 week after the canal was filled, and fl ows were al ready near the maxi mum for the canal. No Phase III tests were conducted at the Uestsi de Ditch Screens. Because operating criteria have not been formal ly submitted, we deci ded that the nost neani ngf ul data would resul $t$ from tests where the canal is operated at near capacity.

\section{PHASE IV}

The i ncl i ned pl ane was used during rel ease and capt ure tests to note the presence of predatory $f i s h$ and the occurrence and condition of nat i ve sal moni ds. The drum screens were moni tored to determi ne if fi sh were i mpi nged. Rai nbow trout fi ngerl i ngs were rel eased at the Uestsi de Ditch Screens to test for possible passage through, around, or over the rotary drum screens. Addi ti onal ly, passage of nati ve chi nook sal mon fry was noni tored. 


\section{IABLE_ 1. Descal ing and Mrtal ity Data from Rel ease and Capt ure Tests wi th Steel head Oncorhynchus myki ss and Spring Chi nook O. tshauytscha Snol ts at the Westsi de Ditch Fi sh Screening Facility, Spring 1989}

\begin{tabular}{|c|c|c|c|c|c|c|c|c|}
\hline \multirow[b]{2}{*}{ SPECI ES } & \multirow[b]{2}{*}{ GROP } & \multicolumn{4}{|c|}{ NUMBER } & \multicolumn{2}{|c|}{ PERCENI } & \multirow{2}{*}{$\begin{array}{c}95 \% \\
\text { CONFI DENCE } \\
\text { I NIERVAL }\end{array}$} \\
\hline & & RELEASED & CAPTURED & OESCALED & DEAD & CAPTURED & OESCALED & \\
\hline $\begin{array}{l}\text { St eel head } \\
\text { St eel head }\end{array}$ & $\begin{array}{c}1 \\
2 \\
\text { TOTAL: }\end{array}$ & $\begin{array}{l}375 \\
375 \\
750\end{array}$ & $\begin{array}{l}304 \\
321 \\
625\end{array}$ & $\begin{array}{r}3 \\
8 \\
11\end{array}$ & $\begin{array}{l}0 \\
0 \\
0\end{array}$ & $\begin{array}{l}81.1 \\
85.6 \\
83.3\end{array}$ & $\begin{array}{l}1.0 \\
2.5 \\
1.8\end{array}$ & $\begin{array}{l}0-3 \\
1-5 \\
1-3\end{array}$ \\
\hline $\begin{array}{l}\text { Chi nook } \\
\text { Chi nook }\end{array}$ & $\begin{array}{c}1 \\
2 \\
\text { TOTAL: }\end{array}$ & $\begin{array}{l}375 \\
380 \\
755\end{array}$ & $\begin{array}{l}371 \\
379 \\
750\end{array}$ & $\begin{array}{l}0 \\
2 \\
2\end{array}$ & $\begin{array}{l}0 \\
0 \\
0\end{array}$ & $\begin{array}{l}98.9 \\
99.7 \\
99.3\end{array}$ & $\begin{array}{l}0.0 \\
0.5 \\
0.3\end{array}$ & $\begin{array}{l}1-0 \\
2-0 \\
1-0\end{array}$ \\
\hline Rai nbow & (Nati & $\cdot$ & 16 & 0 & 0 & & 0.00 & $0-21$ \\
\hline
\end{tabular}




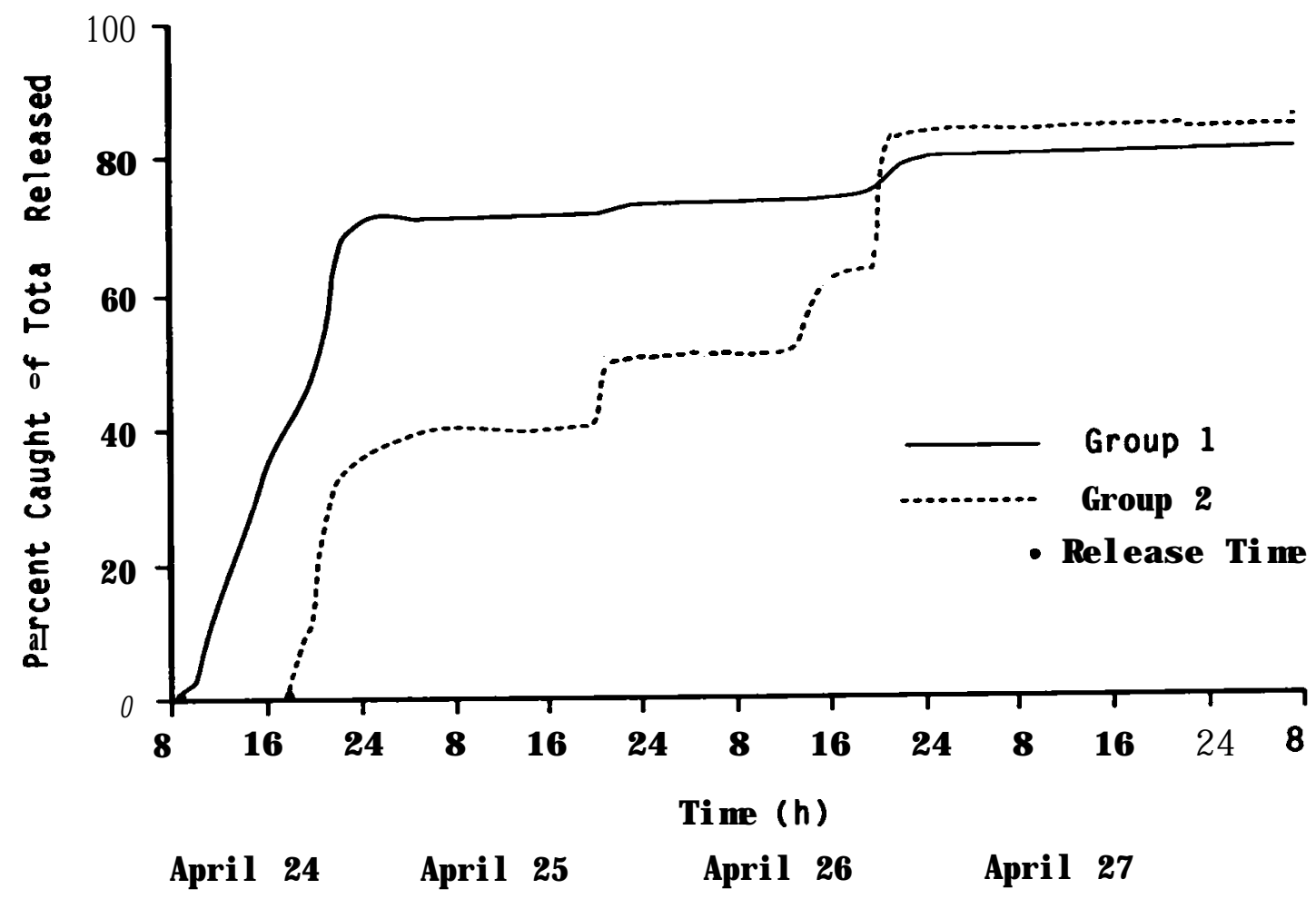

FI GRE. 8 Mbvenent of Steel head Oncorhynchus mykissSnol ts Based on the Capt ure of Test Fi sh at the Uestsi de Ditch Canal Fi sh Screening Facility, Spring 1989

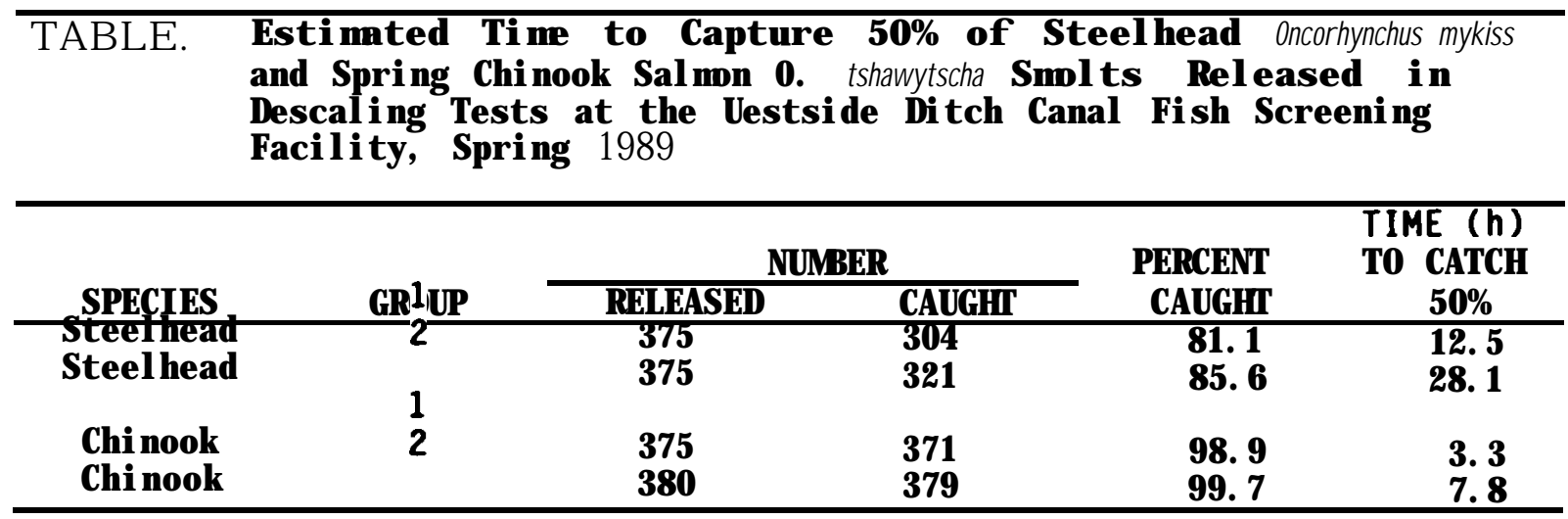




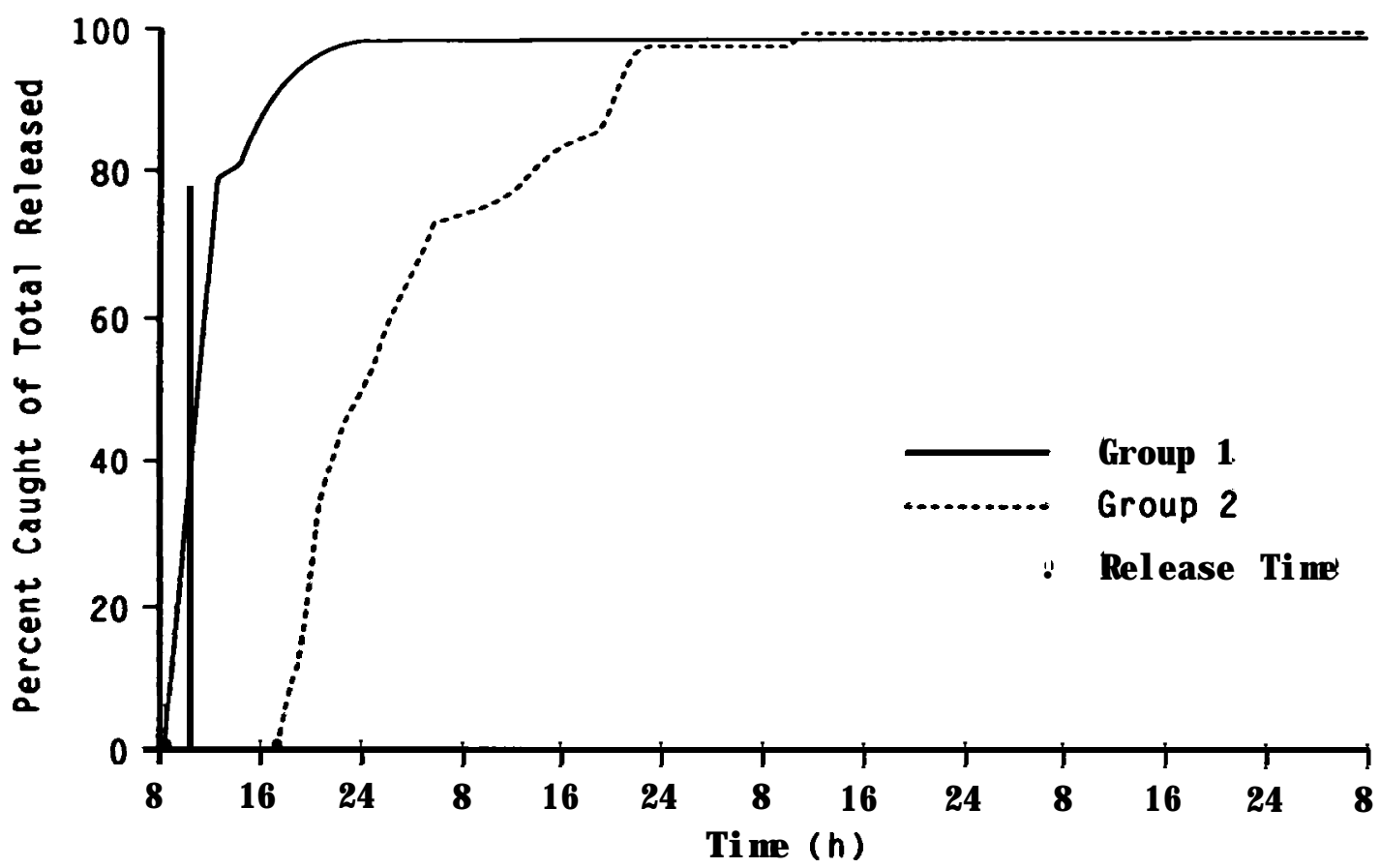

April $24 \quad$ April $25 \quad$ April $26 \quad$ April 27

FI GRE. 9 Mbvenent of Spri ng Chi nook Sal mon Ocorhynchs tstanytscha Based on the Capture of Test Fish at the Uestside Ditch Canal Fi sh Screening Facility. Spring 1989

TABLE. 3 Percent age of Spring Chi nook Sal mon Ocorhynchs tstaytscha Snol ts Descal ed In Pi pe Tests at the Mato Canal Fi sh Screening Facility, Spring 1989

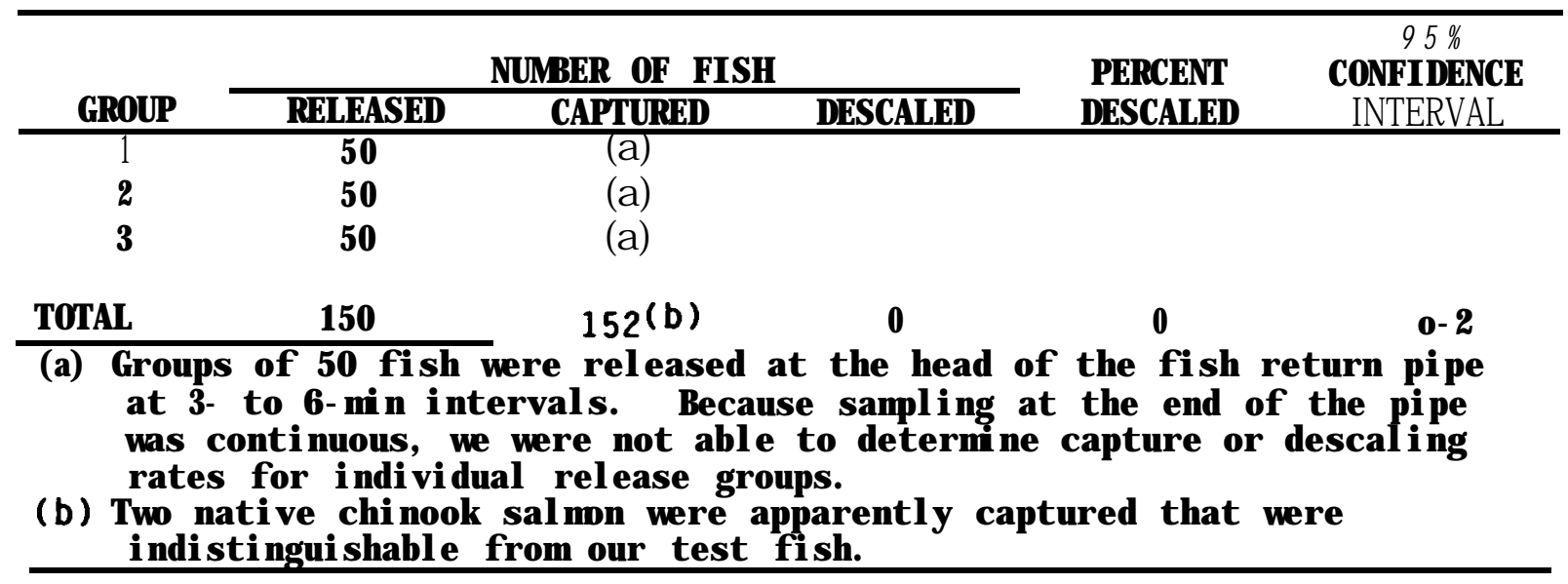


Few nati ve j uveni I e sal noni ds were capt ured during tests at the Uest si de Di tch Screens: however, chi nook sal non fry ( $<40 \mathrm{~mm}$ FL) were common. None of the $16 \mathrm{j}$ uveni l e rai nbow trout and/ or steel head and $1 \mathrm{spri}$ ng chi nook smol t we caught were descaled. The rai nbow trout had not devel oped typi cal snol t characteristics and probably were not steel head. Northern squaufi sh Ptychocheilus oregonensis and one yel I ow perch Perca flavescens were caught on the i ncl i ned pl ane during our tests, but no fi sh were found i $n$ thei $r$ st onach contents.

Phase IVb

A t otal of 3143 rai nbow trout fry (49.3 $\mathrm{mm}$ FL) were rel eased i $n$ front of the screens and 2000 fry were rel eased in the fyke nets behi nd the screens to eval uate screen effectiveness in preventing fish from entering the canal behi nd the screens. Of $3143 \mathrm{fi}$ sh rel eased i $\mathrm{n}$ front of the screens, 508 (16. $2 \%$ were recovered in the fish return and $22(0.8 \%$ were recovered in fyke nets (Table 4). Of the 1200 branded rai nbow trout fry (49.3 mm FL) and 800 unmarked fry ( $36.6 \mathrm{~mm} F \mathrm{~F}$ ) rel eased in fyke nets behi nd the drum screens, $714(59.5 \%$ and 523 (65. 431, respecti vel $y$, were recover ed from the fyke nets.

I n addi ti on to our test $\mathrm{fi}$ sh, 133 chi nook sal mon fry were caught i $\mathbf{n}$ fyke nets behi nd the screens, compared to 650 fry caught on the i ncl i ned pl ane in the fish return during the same period ( Table 5). Most of the chi nook sal mon fry caught on the incl i ned pl ane were capt ured at ni ght. Fry were capt ured in fyke nets behi nd al I four drumscreens (Tabl e 5).

The unmarked rai nbow trout fry rel eased in the nouths of fyke nets for the I ast two screen i ntegrity tests were si milar in gi rth but shorter than the chi nook sal mon fry. Capture rates for the smal I rai nbow was si milar to capt ure rates for the I arger narked rai nbow trout. Capt ure effici ency of the fyke nets vari ed from $56 \%$ to $79 \%$ ( Tabl e 6 ).

Based on the number of $\mathrm{fi}$ sh caught on the $\mathrm{i}$ ncl i ned pl ane and the capt ure effici ency of the fyke nets, about $6.0 \%( \pm 0.35)$ of the rai nbow trout rel eased i $n$ front of the drum screens passed over. around, or through the drum screens. The 133 fal I chi nook fry capt ured in the fyke nets represented $17.0 \%$ of the total number of fry observed during our sampling peri od. When the fyke net capt ure effi ci ency for rai nbow trout is appl $i$ ed to the chi nook sal non capt ure data, we esti nate $24.8 \%( \pm 0.35)$ of chi nook sal mon fry in Uestsi de Ditch passed over, around, or through the drum screens.

Approxi matel y $83 \%$ of the rai nbow trout fry that we pl anted in front of the screens were not recovered. Rai nbow trout fry were not fl ushed from the Uestsi de Ditch Screens forebay. Mbst of the fry hel in the screens 
IABLE 4. Capt ure Data for Rai nbow Trout Fry Ocorhynchsnyliss Rel eased Duri ng Screen I ntegri ty Tests at the Westside Ditch Canal Fish Screening Facility, Spring 1989

\begin{tabular}{|c|c|c|c|c|c|c|c|c|c|}
\hline \multirow{3}{*}{$\begin{array}{l}\text { Test } \\
\text { Group }\end{array}$} & \multirow{3}{*}{$\begin{array}{r}\text { Screen } \\
\text { Number }\end{array}$} & \multicolumn{4}{|c|}{ Number of Control Fi sh } & \multicolumn{4}{|c|}{ Nunber of Test Fi sh } \\
\hline & & Rel eased & Capt ured & Rel eas & pt ured & \multirow[b]{2}{*}{ Rel eased } & \multicolumn{3}{|c|}{ Captured In } \\
\hline & & \multicolumn{2}{|c|}{ Fyke Net } & \multicolumn{2}{|c|}{ PI ane } & & Pl ane & Fyke Net & Other \\
\hline 1 & $1-4$ & 400 & 316 & 100 & 100 & 1047 & 140 & 6 & 5 \\
\hline 2 & $1-4$ & 800 & 448 & 100 & 99 & 1049 & 199 & 10 & 0 \\
\hline 3 & $1-4$ & 800 & 473 & 300 & 300 & 1047 & 169 & 6 & 6 \\
\hline Tot al & & 2000 & 1237 & 500 & 499 & 3143 & 508 & 22 & 11 \\
\hline
\end{tabular}




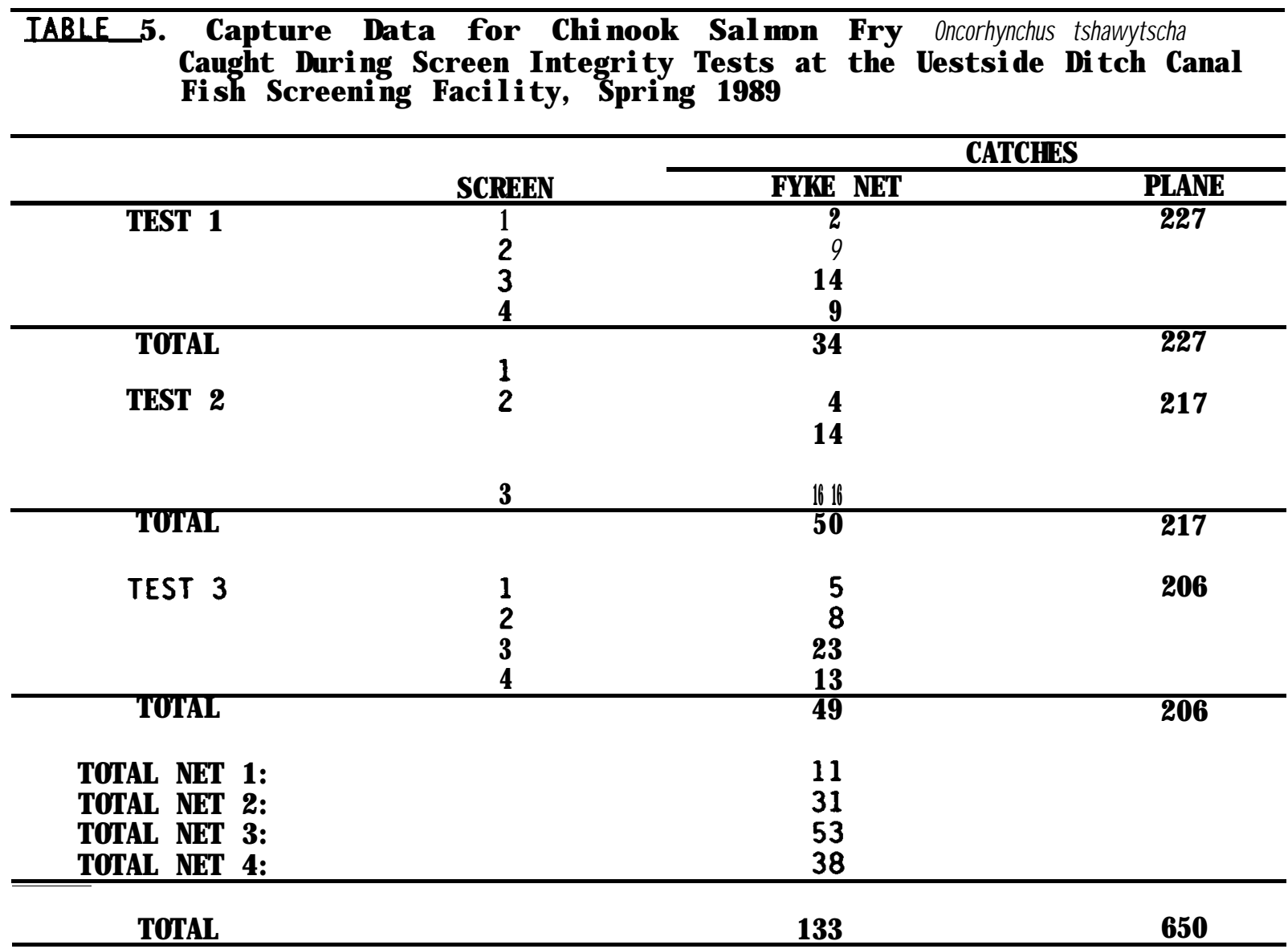

\section{TABLE 6. Capt ure Effi ci ency of the I ncl i ned Pl ane and Fyke Nets Used During Screen Integrity Tests at the Uestsi de Ditch Canal Fi sh Screeni ng Facility, Spring 1989}

\begin{tabular}{|c|c|c|c|c|}
\hline TEST & $\begin{array}{rlr}\text { CAPTURE } & \text { PROBABI LI TY } \\
\text { I NCLI NED PLANE } & \text { FLA }\end{array}$ & $\frac{Y \text { ESTI MATE }}{\text { FYKE NET }}$ & $\begin{array}{l}\text { SCREEN } \\
\text { EFFI Cl ENCY }\end{array}$ & $\begin{array}{c}957 \\
\text { CONFI DENCE } \\
\text { I NIERVAL }\end{array}$ \\
\hline $\begin{array}{l}\text { Ra i nbaw } \\
1 \\
3 \\
3 \\
3\end{array}$ & $\begin{array}{r}\text { Trout } \\
1.000 \\
0.990 \\
1.000\end{array}$ & $\begin{array}{l}0.790 \\
0.560 \\
0.591\end{array}$ & $\begin{array}{l}0.949 \\
0.918 \\
0.943\end{array}$ & $\begin{array}{l}0.91-0.99 \\
0.86-0.98 \\
0.89-1.00\end{array}$ \\
\hline Total & 0.998 & 0.619 & 0.935 & $0.90-0.97$ \\
\hline $\begin{array}{l}\text { Chi nook } \\
1 \\
2 \\
3\end{array}$ & $\begin{array}{r}\text { Sal mon } \\
1.000 \\
0.990 \\
1.000\end{array}$ & $\begin{array}{l}0.790 \\
0.560 \\
0.591\end{array}$ & $\begin{array}{l}0.841 \\
0.711 \\
0.713\end{array}$ & $\begin{array}{l}0.79-0.89 \\
0.65-0.78 \\
0.65-0.78\end{array}$ \\
\hline Total & 0.998 & 0.619 & 0.752 & $0.72-0.79$ \\
\hline
\end{tabular}


forebay; however, some fish were I ost to predati on by our test fi sh. Fi sh from each of the three rel ease groups were caught throughout the duration of sampl i ng, wi th movenent i ncreasi ng at sunset ( Fi gure 10).

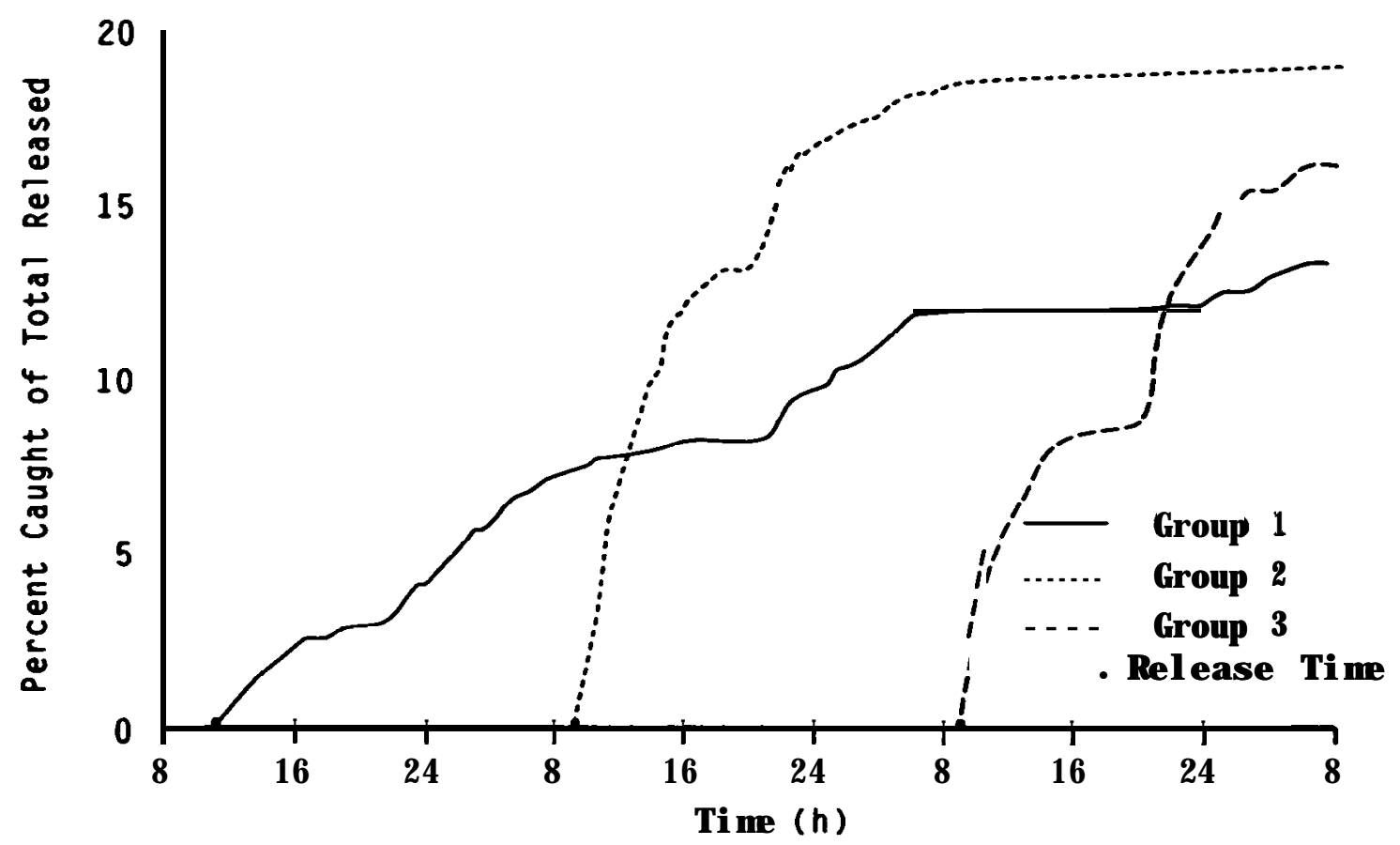

Apri I 25

Apri I 26

Apri I 27

EIGURE 10. Mbvenent of Rai nbow Trout Oncorhynchus myki ss Fry Based on the Capt ure of Test Fish in the Bypass During Screen Integrity Tests at the Westsi de Ditch Canal Fi sh Screening Faci lity, Spring 1989 
Fi sh screening facilities in the Yaki masi $n$ are designed to di rect fish that have been di verted from the river i nto i rrigation canal s back to the river wi thout killing or i njuring them or del aying thei $r$ migation. The uork pl an for this study was desi gned to determine if the di verted fi sh can be safel $y$ and expedi ti ousl y returned to the river. Tests foll owing the work pl an were conducted to: 1) eval uate the condi ti ons or ci rcunstances that affect fish survival as the fish pass through the screening facility. 2) determine if a screeni ng facility provides conditions under which di verted fi sh may becone nore suscepti bl e to predati on, 3) eval uate whether fish are del ayed at or upstream of the screening facilities, and 4) determine if fish pass through, around. or over rotary drum screens and becone trapped in the i rrigation canal.

\section{ELSH SURM VAL AT SCREEN NG FACLITIES}

Based on rel ease/ capt ure tests at si $x$ screeni ng facilities, fish are not descal ed or killed during passage in front of the rotary drumscreens or through the fish bypass systens. As in previ ous descal ing eval uations at the Sunnysi de, Ri chl and. Toppeni sh/Sat us. Toppeni sh Creek. and Whato Screens. the descaling rate for test fish at the Westsi de Ditch Screens wi thi $n$ the confidence li mits for control fish.

Fi sh were not inj ured from passing through the fish ret urn pi pe at the Whato Canal Fish Screening Facility. The small descaling rate observed in previ ous tests of the fish ret urn pi pe (Neitzel et al. 1988) was the product of the col l ecti on techni que and equi pnent. $\mathrm{Nb}$ descal ing was observed due to passage through the pi pe or from the col l ecti on equi pment in tests conducted this year.

\section{POTENTI AL FOR PREDATI ON AT SCREEN NG FAO LI TI ES}

On the basi s of the sampl es we have collected, I oss to predati on does not appear to be a problemat screening facilities when onl y nati ve speci es are i nvol ved. However, hatchery-rel eased sal moni ds that take up temporary resi dence in a screens forebay my i ncrease predati on pressure at screen si tes. Screening faciliti es coul d affect the predator/prey rel ationshi $p$ if the screens concentrate prey or i ncrease the exposure of prey to predators because of stress, i nj ury, or del ay in migration.

\section{Westsi de Ditch Screens}

$\mathrm{Nb}$ predati on was observed at the Westsi de Ditch Screens. al though some rai nbow trout fry rel eased for Phase I Vb tests nere consuned by st eel head snol ts we rel eased for Phase IIb tests. Predation, theref ore. appeared to 
be rel ated to the artificial and temporary predator/prey population structure created by the rel ease of our test fish. A though many chi nook sal mon fry were caught during tests at the Uestsi de Ditch Screens, few snolt-si ze sal moni ds were caught, indi cating that the snol ts had al ready migrated from the reach of the Yaki ma Ri ver upstream of the Westsi de $D$ t $c h$ Canal or that j uveni le sal mon do not overwi nter i n the reach. Regardl ess, the nat ural predator/prey popul ati on structure in the screens forebay shoul d be si milar to that in the Yaki ma Ri ver because fi sh movement through the screens forebay is not i mpai red when adequate bypass fl ous are provi ded.

BOTENTIAQL FOR FISH DELAY AT SCREENING FACU ITIFS

One of the basi c objecti ves of redesi gni ng and constructing new screens is to provi de facilities that safely and rapidly return fi sh fromdi versi on canal s to the river (Easterbrooks 1984). Fi sh are not "fI ushed" from the screen forebay back to the river, al though the screening facilities do not i mpede vol untary novenent and migration under normal operating condi tions. Conversel $y$, i nadequate bypass fl ous resul ti ng from i mproper operation, i noperable components in the bypass system I ow canal fl ous or for ebay el evati ons, or bl ockages in the fi sh ret urn can i mpai $r$ the movenent of fi sh through the fish bypass system and contribute to del ays in migration.

Fl ow through the fi sh return pi pe at the Wistsi de Ditch Screens was severel y restricted bef ore we i nitiated our tests. Normal fi sh bypass fl ous were not attai nabl e because the fish return sl ot was backed up with water. In the week preceding our tests, we observed several smal I chi nook sal mon fry hol ding in the fish return slot. The head of the fish return pi pe was pl ugged with debris that ei ther washed into the fish return sl ot when the canal was filled or was not renoved before startup. Besi des restricting water fl ow and fish movenent, a partially pl ugged pi pe nould i nj ure fish.

\section{EISH PASSAGE THROUGH OR OYER ROTARY DRUM SCREENS}

The sueeping to approach vel ocity ratio designed into the facilities hel ps to gui de fish into the fish bypass. and screen mesh openi ngs $(3.2 \mathrm{~mm} / / 8$ in.) are snal I enough to prevent most sal nonid fry from passing through the drum screens. Tests nere desi gned and accompl i shed at the Westsi de Ditch Screens to determine if any $\mathrm{fish}$ might be i mpinged by or passed over, around or through the drum screens.

\section{Westside Ditch Screens}

Fi sh rel eased in the screens forebay were caught i $\mathbf{n}$ fyke nets behi nd al I four of the drum screens. Sone of the fish caught behi nd the screens were the result of "rollover" of fish rel eased at the water surface near the 
screen face. However, rollover accounted for onl y a smal l percentage of the total number of $f i$ sh caught behind the screens. The passage rate for chi nook sal mon fry was four ti mes greater than for our test fish, and was due ei ther to the snaller si ze of the chi nook sal non or to a difference i n behavi or. No rol l over was observed for chi nook sal mon fry. However, the fish noved at ni ght when rollover observations are difficul $t$.

The I/8-in. screen mesh used in the construction of the drum screens at the Westsi de Ditch Canal and nost other screening facilities is bel i eved to be snal I enough to prevent sal monid fry frompassing through the mesh. However, the smal l er chi nook sal mon fry capt ured in the fyke nets behi nd the drum screens could be "pushed" through the mesh wi thout apparent i nj ury. Chi nook sal mon fry 32 to $40 \mathrm{~mm}$ in I ength could not pass through a 5/32-i n. screen openi ng ( Fi sher 1978); however, the tests vere conduct ed with perforated $\mathrm{pl}$ ate, and not with the coarse woven wi re mesh used in the construction of the drum screens.

Fi sh potenti al Iy can pass around the drumscreens at Westsi de Ditch. A though the seal s around the ci rcunference at each end of the screens appear tight, snall gaps around the end frames of the drum screens are evi dent. 
SUMMARY

Rel ease and capt ure tests and ot her moni toring st udi es have been conducted at si $x$ di versi on screen facilities in the Yaki ma Basi n: the Sunnysi de Screens (Neitzel et al. 1985), the Richland and Toppeni sh/Sat us Screens ( Nei tzel et al. 1986). the Whpato Screens ( Neitzel et al. 1988), the Toppeni sh Creek Screens ( Neitzel et al. 1989), and the Westsi de Ditch Screens. The obj ecti ve of our eval uati ons was to determi ne whet her or not fi sh that have entered a i rri gati on canal are saf el y di verted back to the river. The objective was met by determining if: 1) fish that pass through the di versi on are killed, i nj ured, or eaten by predators; 2) fi sh migration is del ayed at the screen structure: and 3) fi sh are prevented from passi ng through or over the screens. These obj ectives are addressed in the vari ous phases of the nork pl an.

\section{PHASE I}

Phase I tests conducted at the Sunnysi de Screens in 1985 used chi nook sal mon and steel head snolts. The test data indi cated that fi sh safely pass through al I components of the fish bypass system $\mathrm{Nb}$ Phase I tests have been conduct ed at the $\mathrm{Ri} \mathrm{chl}$ and. Toppeni sh/Sat us. Toppeni sh Creek. or Westsi de $D i$ tch Screens, because the fi sh bypass systens di d not i ncorporate internedi ate and termi nal bypasses, travel ing screens, or fish water pumpback systens in thei $r$ desi gns. $\mathrm{Nb}$ Phase I tests were conducted at the Whato Screens, because none of the components of the fish passage facility differed si gni fi cantly from components at the Sunnysi de Screens, whi ch were proven safe for fish passage.

\section{PHASE II}

Phase Ila tests have been compl eted at al I si x screening facilities. At the Sunnysi de Screens, fi sh were rel eased ei ther at the trash racks or the head gates. Fi sh capt ured af ter novi ng through the screen for ebay and di versi on system uere not i nj ured or killed. At the Ri chl and, Toppeni sh/Sat us, Whato, and Toppeni sh Creek Screens, fi sh were rel eased onl $y$ at the trash racks, and $f i s h$ were rel eased i $n$ the canal upstream of the screens at the Westsi de Ditch Screens. Capt ured fi sh were not killed or i nj ured. Tests at the Sunnysi de, Wapato. Ri chl and, and Westsi de Di tch Screens were conducted with chi nook sal mon and steel head snol ts. Tests at the Toppeni sh/Sat us and Toppeni sh Creek Screens were conducted with st eel head snol ts onl y.

Phase Ilb tests have been conducted at the Sunnysi de. Ri chl and. Toppeni sh Creek, and Whato Screens. At Sunnysi de. tests were conducted to eval uate the i nt er medi ate bypass system the termi nal bypass system the secondary separation chanber, and the pri mary fish return pi pe. At the Richl and. 
Toppeni sh Creek, and Wapato Screens, the fi sh return pi pe was eval uated. Fi sh successful ly passed through each of the components wi thout inj ury or del ay.

PHASE $\amalg$

Phase III tests have been conducted at the Ri chl and, Toppeni sh Creek. and Whato Screens. Pi pe tests were conducted under two bypass fl ous at the $\mathrm{Ri}$ Chl and Screens. Fi sh were not i nj ured or killed at ei ther bypass fl ow Eval uations at the Toppeni sh Creek and Whato Screens were conducted during I ow and full canal fl ow condi tions. Fi sh were not i nj ured or killed in ei ther test: however, novenent rate was sl ower during I ow canal fl ow conditions. Opportunities to conduct tests under different canal fl ous have been I i mited because of del ays i $n$ construction and start up at the Sunnysi de. Ri chl and. and Toppeni sh/ Sat us Screens. The Sunnysi de, Toppeni sh/ Sat us. and Westsi de Ditch Screens were eval uated onl y at ful I canal fl ow condi ti ons and the Richl and Screens onl y at mi mum fl ow condi ti ons.

\section{PHASE IV}

Nati ve fi sh were col l ected during al I bypass tests and the gut contents of predaci ous fi sh were exami ned. Predaci ous bi rd acti vity uas al so moni tored in the vi cinity of each screening facility. Increased predation does not occur at screening facilities, except that hatchery-rel eased sal nonids someti mes congregate in the screens forebay and prey on sal nonid fry.

Rotary drum screens were examined during bypass tests to determine if any fi sh were i minged on or passed over the screens. Successf ul screen integrity tests have been compl eted at the Ri chl and, Toppeni sh Creek. Sunnysi de. Whato. and Wéstsi de Ditch Screens. The Ri chl and Screens are effective at preventing fish from entering the irrigation canal: however, some fi sh passed over the screens and through faulty screen seal s at the Toppeni sh Creek, Sunnysi de. Whato. and Westsi de Ditch Screens. Screen integrity tests initiated at the Toppeni sh/Sat us Screens were not completed because ue di d not have nets to capt ure fish dounstream of the rotary screens. 


\section{RECOMMENDALIONS}

Fi sheri es eval uations have been conducted at si $x$ di versi on screen faci I i ti es: the Sunnysi de. Ri chl and. Toppeni sh/Sat us. Whato. Toppeni sh Creek, and Wéstsi de Ditch Screens. Data were collected to address fi ve areas of concern: fi sh survi val, predation, mi grati on del ays, screen passage, and effects of operating conditions. The results of tests addressi ng each concern were i nt egrated to eval uate the ef fecti veness of the screens.

The data i ndi cate that fi sh are not descal ed or killed as they are di verted by the screening facilities: however. descaling tests should conti nue at fut ure di versi on si tes to assess potential site-specific problens.

Emphasi s should be pl aced on correl ating descaling to canal operations (Phase III). The periods when canal operating condi ti ons are of greatest concern are 1) during canal startup and 2) during peak migration of nati ve sal monid stocks in the vi ci nity of each screening facility.

I ncreased predati on does not seem to occur at screening facilities, except when hat chery-rel eased sal noni ds someti mes congregate in the screens forebay. and prey on sal nonid fry. The potential i mpact of predation i n the screen forebays can onl $y$ be assessed if predation in the screen forebay is compared to predation in the river.

Fish successfully pass through the screen facilities of thei $r$ own volition. Fi sh are not "fl ushed" from the screen forebays and can remi $n$ in the forebays. The potent $i$ al i mpact of migrati on del ay i $n$ the screen forebays can onl $y$ be assessed when migration ti $\mathrm{ming}$ through the screen forebays is compared to migration ti ming in the river.

Tests to evaluate screen i ntegrity shoul d conti nue to have hi gh pri ority. The screen integrity tests we compl eted at the Toppeni sh Creek. Sunnysi de. Whato, and Westsi de Ditch Screens i ndi cate that screen seal s pl ay a vi tal role in preventing fish from entering the irrigation canal. Annual i nspecti on and repl acement of screen seal s might reduce losses: however, a new seal design may be necessary if the present loss rate is not accept able.

Moni tori ng of chi nook sal non fry should be conducted at the Westsi de Ditch Screens after the problens with end seal s have been resol ved. The Department of Fi sheri es has suggested that the frames be "crouded" upstream in the structure bl ockouts and wedged to cl ose the gaps bef ore the canal is filled.

The wi re mesh used for the construction of drum screens shoul d be tested to verify that fish can not pass through the mesh. Chi nook sal non fry capt ured in fut ure screen eval uations could be used as test fish. 
The fi sh bypass systens are operated fol l owing criteria for fl ous through the fl ow control gates, fish return pi pes, and other bypass structures. These operating condi ti ons are set to protect fi sh that move through the system It is i mperative that the operating conditions are adhered to when fish are noving through the di versi ons. Operating conditions need to be publ i shed and should cover al I operating conditions for each facility. Facility structures, such as water el evation markers, must be instal led at al I facilities so operating criteria can be properly i mplenented.

The fi sh bypass system shoul d be thoroughl y checked and cal i brated at each screening facility at the beginning of each irrigation season. Operating criteria should stress that $f$ ish bypass fl ow is very i mportant in achi eving effective fish bypass. Fish are not invol untarily del ayed at or wi thi $n$ the screening facilities when bypass fl ous are set according to the operating criteria and properly mi ntai ned. Debris that bl ocked the head of the fish ret urn pi pe at the Westsi de Ditch Screens resul ted i $n$ reduced bypass fl ous and was a potential site for inj ury to fish. 


\section{REFERENCES}

Basham, L. R. M. R. Del arm J. B. Athern, and S. W Pettit. 1982. Fish Iransportation Oversiaht Team Annual eoort. FY 1981:-Transoort_odera tions on the Snake and Col unbi a Ri ver: . Techni cal Servi ces Di vi si on, Northwest Regi onal Office. Nati onal Oceani $c$ and At nospheric Admi ni strati on, Nati onal Mari ne Fi sheri es Servi ce, Portl and, Oregon.

Bureau of Recl anation. 1984. Finding of No Significant I mact: Fish Passaae and Protectíve Faci'li'tles. Yakl ma Ri'ver Basi'n. Washington. Bur eau of Recl anati on. Paci fi c Northwest Regi on, Boi se. I daho.

East erbrooks. J. A 1984 . Juvenile Fi sh Screen Desi an Criteria: A Revi' ew of the Objectives and Scientific Data Base. State of Whshingt on Department of Fi sheri es, Habi tat Managenent Di vi si on, Yaki ma. Whishi ngt on.

Fast, D. . J. Hubble, and B. Wht son. 1986. Yaki na Ri ver Spring Chi nook Enhancement Studv Fi sheri es Resources Manaaement. Yaki ma I ndi an Nati on Prepared by the Di vi si on of Fi sheries, Yaki na I ndi an Nati on, for the. Bonnevi I l e Pouer Admi ni strati on, Portl and. Oregon.

Fi sher, D. W 1978. Protecti on of of King Sal mon and Ameri can Shad with Perforated Plate and Vire Mesh Screens. Cal i forni a Fi sh and Gane, 7818, Sacrament o, Cal i f or ni a.

Hol I owed, J. J. 1984. 1983 Yakl'na Ri ver Fal I Fi sh Counts at Prosser_Dam. Yaki ma I ndi an Nati on, Fi sheri es Resource Managenent Techni cal Report $\mathbf{N b}$. 84- 11. Yaki ma I ndi an Nati on, Toppeni sh. Whshi ngt on.

Hol man. J. P. 1971. Experi mental Methods for Engineers. MtGraw Hill, New York.

Mai nl and, D. , L. Herrera, and M I. Sutcl iffe. 1956. Tables for Use with B. nial Samples. Mi nl and, Herrera, and Sutcl iffe. New York.

Mood, A M. F. A GraybilI, and D. C. Boes. 1974. Introduction to the Iheory of Statistics, MtGaw HII, New York.

Neitzel, D. A, C. S. Abernethy, and E. W Lusty. 1990. A Fi sheries Eval uati on of the Joppenish Creek. Mapate. and Sunnyside Fish Screening ing 1988. Prepared by the Pacific Northwest Laboratory, Ri chl and. Wishingt on, for the Di vi si on of Fi sh and Vil dl i fe, Bonnevili e Power Admi ni strati on, Portl and, Oregon.

Nei tzel, D. A, C. S. Abernethy, E. W Lusty. and S. J. Whmpl er. 1988. A Eval uati on of the Richland and Whato Canal Fi sh Screeni ng Facilities. Soring 1987. Prepared by the Pacific Northwest Laboratory. Ri chl and, Wishi ngt on, for the Di vi si on of Fi sh and Vil dl i fe, Bonneville Power Admi ni strati on. Portl and. Oregon. 
Neitzel. D. A, C. S. Abernethy. and E. W Lusty. 1986. Afisheries Evaluation of the Richland and Toppenish/Satus Canal Fish Screening acilities. Soring 1986 Prepared by the Pacific Northwest Laboratory. Ri chl and, Whshi ngt on for the Di vi si on of Fi sh and Vil dl i fe, Bonnevill e Pouer Admi ni strati on, Portl and, Oregon.

Neitzel. D. A, C. S. Abernethy. E. W Lusty, and L. A Prohamer. 1985. $\Delta F^{\prime}$ 'Evaluation of the Sunnvsi de Canal Fish Screening Facility. Spring 1985. Prepared by the Pacific Northwest Laboratory, Ri chl and. Washington, for the Di vi si on of Fi sh and Vil dl i fe, Bonnevil I e Power Admi ni strati on, Portl and, Oregon. 


\title{
APPEMDIX A
}

\author{
WORK PIAN
}

The work plan for al I BPA funded screen eval uati ons i ncl udes four phases. Phases I through III are mark/rel ease studi es to determi ne changes in fi sh condition and transit time through the screen facilities. Phase IV is a nonitoring study to determine presence of predators near the screen facili ti es, passage through the di versions into the canal s. and arrival ti mes at the screen facilities for migrating populations of fish.

The work pl an addresses a generi c facility (i.e.. head gates, trash rack. screens. fi sh- water-pumpback system separati on chanber. and fi sh ret urn pi pe). Some of the facility components may be different or not used at a gi ven facility; however, the four-phase concept will be appl i ed as much as possi ble. Addi ti onal ly, it is not al uays possi ble to i mpl enent al l phases at al I si tes. The most i mportant data needed to eval uate a specific screen si te are determined by the fi sheri es managenent agenci es in the Yaki ma Basi $n$. Thi s decisi on then determi nes the phase of the uork pl an to be i mpl enented fi rst at a si te.

\section{PHASE I}

Phase I tests are conducted to determi ne the condi $t i$ on of fish af ter passage through the fish di versi on components of the screen facility. Phase I is accompl i shed by rel easing branded fish at the entry to the fish bypass system Rel eased $\mathrm{fish}$ are collected near the terminus of the fish return pi pe. The percentage of descaling, the number of fish killed (both i medi atel $y$ and after 4 days). and the rates and extent of i nj uri es are recor ded.

Several collecti on systens are consi dered, i ncl uding a net at the terminus of the pri mary fish return pi pe and a modi fi ed i ncl i ned pl ane or net near the terminus of the di versi on system The coll ecti on system is chosen af ter a site-specific eval uation of the screen facility. Collection systens are tested to determ ne thei $r$ effecti veness and to make sure collected $f i s h$ are not bei ng injured or stressed by the system These tests are conducted by rel easing fish $i n$ and near the collection system Efficiency and handl ing tests are conducted throughout the eval uati on tests.

Col I ecti on of rel eased $f i$ sh begi ns $i$ medi atel $y$ on rel ease. Col l ecti on duration and interval varies with the site and the test objective. Where the pri mary objective is to esti mate the proporti on of the rel eased $f i s h$ that are killed or descaled. we fish until we get a $95 \%$ confidence interval esti mate that is acceptable. When we are esti mating the travel ti me through a component of the screen facility, we use a si miar criterion for 
devel oping a sample durati on. Sampl es are col l ected conti nuousl y, if possible, during the first 24 to $48 \mathrm{~h}$ after rel ease. If a higher catch total is requi red after $48 \mathrm{~h}$. col lection will be made to the peri od of hi ghest probable catch for the next $48 \mathrm{~h}$.

A hypothesi s as to the $f$ ate of the noncol I ected fi sh for each rel ease wi I be devel oped on the basi s of the catch ef $i$ ci ency data that we col lect during the control tests, the duration of the sample effort, and data from repl i cate tests when avai l abl e.

Expected resul ts from Phase I data i ncl ude 1) the percentage of fi sh that are killed or descal ed during passage through the fish bypass system in the screen di versi on. 2) the change in condi ti on for the fi sh that survi ve passage through the bypass. 3) a hypothesi s as to the fate of the noncol lected fish, 4) the potential effects of sampl ing equi pnent. and 5) the handling effects of the mark, rel ease, and capt ure techni ques.

PHASF 11

Phase II tests are conducted to determi ne the condi ti on of fish after passage from upstream of the trash racks through the bypass system (Phase Ila) or after passage through i ndi vi dual fi sh passage components of the screen facility (Phase IIb). The choice of which test to use depends on whether or not fish are killed or i nj ured during Phase I. If there are no nortalities or injuries after passage through the bypass system during Phase I, Phase Ila fol I ous Phase I. If there are nortalities or inj uries during Phase I. Phase IIb fol I ous Phase I.

P h a se.

If no effect is observed in Phase I. the condi ti on of fish that pass through the screen facility (from upstream of the trash racks through the bypass) is determined. The speci es tested is the same as used in Phase I, if possi ble.

Fish are released at the trash rack. Fish are collected at the terminus of the fish return pi pe. The percent descaling, the number killed ( $i$ medi atel y and after 4 days). and the rates and extent of i nj uri es are noted. Rel eases are made i $n$ and near the col l ecti on system to determi ne collection effici ency and handling effects.

St udy obj ecti ves addressed are 1 ) the condi ti on of fi sh that enter the headworks of the canal and are subsequently ret urned to the ri ver through the primary fish ret urn pi pe and 2) transit ti me from the trash racks to the ri ver di scharge.

Expected resul ts from these data i ncl ude 1) the change i $n$ condi ti on for fi sh that pass through the enti re fish di versi on and are ret urned to the 
river, 2) a hypothesi s as to the fate of noncol l ected fi sh. 3) the transit ti me for fish through the facility, and 4) collection efficiency and handl ing ef fects.

Phase IIb.

If an effect is observed in Phase I. the condition of $f i$ sh that pass through i ndi vi dual components of the fi sh bypass system i ncl udi ng the i nt er medi ate bypass pi pe, the secondary separati on chanber. the travel ing screens, and the primary fish return pi pe, will be determined. The species tested are the same as used in Phase I. if possi bl e. The number rel eased are determined by using the same criteria used in Phase I.

Fi sh are rel eased i $n$ indi vi dual components of the bypass system The fi sh are collected at the terminus of the component or at the terminus of the pri mary fish return pi pe, depending on the data needed and the possibility of sampl ing wi thi $n$ the component.

St udy obj ecti ves addressed are condi ti on of $\mathrm{fish}$ at the di scharge. condition of $\mathrm{fish}$ through the bypass and secondary separation chamber, transit ti ne across the facility. and transit ti me through the secondary separati on chanber.

Expected results from these data i ncl ude i denti fication of 1) a hypothesi s as to the fate of noncol l ected fish, 2) the bypass components that adversel $y$ affect the condition of $f i$ sh passing through the fish screen facility, and 3) possible changes to the screen facility to reduce i dentifi ed effects.

\section{PHASE 11 .}

Phase III tests are conducted to determi ne screen operating condi ti ons and canal flow changes that may affect the efficiency of the screens. The test desi gn, test organi sns, and nost study obj ecti ves are the sane as those in Phases I and IIa. Study objectives addressed are operational condi ti ons that naxi mize screen effici ency, ef fecti veness of the screens over a range of fl ous, and factors that affect fish transit ti ne through the facilities.

Expected resul ts from these data i ncl ude 1) determi nati on of any change i $n$ the effectiveness of the facility over a range of canal fl ous, and 2) exami nati on of factors that may change the transit ti me through the faci lity. 


\section{PHASE IY}

Phase IV monit toring is conducted to determi ne if pi sci vorous predators are present near the screen facility and if fish can pass through or over the screen facility into the canal.

Phase IV has two parts: both are moni toring studies. Phase IVa is desi gned to exami ne presence and temporal di stributi on of predators near the screens, and Phase I $\mathrm{Vb}$ is desi gned to exami ne rates of i mpi ngenent on the screens.

Ph a se.

Phase I Va i ncl udes use of an i ncl i ned pl ane, fyke nets, beach sei nes. of el ectroshocker to nonit or presence and temporal di stribution of nat ural fi sh populations in the area of the facility. Proposed l ocations for moni toring are downstream of the headworks. in the canal downstream of the facility, and in the river downstream of the di scharge.

The col l ecti on equi pment are used at predesi gnated ti mes. Sample duration is determined by consul tati on with BPA and Yaki ma Basi $n$ fi sheries agenci es and the priority of the Phase IV uork. Phase IVa monitoring at the i ncli ned pl ane conti nue during every mark/rel ease test. The presence and quantity of any predators are noted.

St udy obj ecti ves addressed are the presence of fi sh popul at i ons near the facility and fish passage through the facility.

Expected resul ts from these data i ncl ude 1) a qual itati ve determi nation of the fish predat or popul ations in the area of the facility, 2) an eval uation of effectiveness of the screens in keeping fish from entering the canal downstream of the screens, and 3) the arrival ti me at the screen facility for sal moni d popul ati ons.

\section{Phase I Vb.}

Phase I Vb moni toring exami nes the rotating screens and the verti cal travel ing screens.

If necessary. Phase I $\mathrm{Vb}$ obj ecti ves may be met with a task other than monit oring. For exampl e, marked fi sh my have to be rel eased in front of the screens, and subsequent moni toring behi nd the screens will indi cate whether or not fish are able enter the canal through or over the screens.

The st udy obj ecti ve is to address the rates of i mpi ngenent on the rot at ing and travel ing screens. 
Expected resul ts from these data i ncl ude 1) the rate of i npi ngenent on the rotati ng screens, 2) the rate of i mpi ngement on the travel ing screens, and 3) the operati onal condi ti ons that resul $t$ i $n$ i ncreased i mpi ngenent.

Thi s task will not be necessary if i mpi ngenent does not occur during operation of the facility. This is eval uated during Phase I and II. 


\section{APPEADIX B}

BELEASE AND CAPTURE DATA FROM SUMMYSIDE. RICHLAND. TOPPENISH/SATUS. MAPATO. IOPPENISH CREEK. AND VESTSI DE D TCH CANAL FISH SCREEN NG FACI LI TIES

Thi s appendi $x$ contai ns data col l ected during 1985 through 1989 at Sunnysi de ( Nei tzel et al . 1985, 1990). Ri chl and (Nei tzel et al . 1986. 1988).

Toppeni sh/ Sat us ( Nei tzel et al. 1986). Whpato (Nei tzel et al. 1988. 1990) and Toppeni sh Creek ( Neitzel et al. 1990) Canal Fi sh Screeni ng Facilities. Addi ti onal I y, the data collected during 1989 at Westsi de Ditch and Whato Screens are presented. Data presented in the Results sections are soneti nes combi ned (i.e. . i ndi vi dual trial s withi $n$ a test series were conbi ned for a single esti mate). In this appendi $x$ we are trying to present the data from each oft he i ndi vi dual trial s that were conducted. Descaled fi sh were considered dead for the esti mates presented here. as they were in the Results sections of each of the annual reports. Dead and descal ed $f$ ish were conbi ned to evaluate screen performance.

Data from the Sunnys ide Screens ( Neitzel et al. 1985) i ndi cate that fi sh are safel y di verted from the canal to the river. Data are presented in Tabl es B.I through 8. 7. The data in Tabl es B.I and 8.2 represent eval ua$t i$ on of the $i$ ncl $i$ ned $p l$ ane and fyke net. Both samplers collected fi sh without killing or descaling the fish. Data in Tables B. 3 and 8.4 are eval uations of the condition of test $f i$ sh before rel ease in the canal or screen facility. Test fish were in good conditi on bef ore thei $r$ rel ease. Data in Tables B. 5 and 8.6 are the results of the screening facility eval uations. Descaling data from upriver hatchery and native fi sh are presented in Table 8. 7. Data in Table 8.45 are the esti nated ti nes for test fish to nove through the Sunnysi de Screen Facility. The screen integrity tests indi cate that less than $2 \%$ of test fish pass through or over the screens. The screen integrity data are presented in Tables 8.46 through 8. 48.

Dat a from the Ri chl and Screens (Neitzel et al. 1986. 1988) eval uati on indi cate that fish are safely diverted from the canal to the river. Data from the 1986 eval uati on are presented in Tables B. 8 through 8.15 and from the 1987 eval uati on i $n$ Tabl es 8. 25 and 8. 29. Data in Tabl es 8. 8 and 8.9 are from the eval uation of the $i$ nclined $p l$ ane and the fyke net. The i ncli ned plane safely collected fish. The fyke net descal ed too many fish to be used as an ef fective collection device at the terminus of the $\mathrm{Ri}$ chl and Canal fi sh ret urn pi pe during fl ous of $0.6 \mathrm{~m} / \mathrm{s}$ ( $20 \mathrm{cfs}$ ). Ther ef ore. we used an el ectroshocker to col l ect fi sh during the eval uati on of the fish return pi pe. Data i $n$ Tables B.10 and 8.11 are eval uati ons of the condi ti on of the test fish bef ore thei $r$ rel ease i nto the canal. Fi sh were in good condition bef ore rel ease. Data in Tables 8.12 and 8.13 are the results of screening facility eval uations. Data in Table 6.14 are the esti mated ti mes for test fish to move through the Richl and Screen Facility. 
Descal ing data from upriver hatchery and native fish are presented in Table B- 15 ( 1986 data) and Table 8. 25 ( 1987 data). The screen i ntegrity data col l ected at Ri chl and Canal i n 1987 are presented i n Table 8. 29.

Data from the Toppeni sh/ Sat us Screens eval uati on i ndi cate that fi sh are saf el y di verted from the canal to the river. Data are presented in ables B.16 through B.19. Data i n Tabl e B. 16 are eval uati ons of the condi $t$ on of the test $f i s h$ bef ore rel ease in the canal. The fi sh were in nargi na condition bef ore testing. The water temperature at the canal during testing was near $20^{\circ} \mathrm{C}$; theref ore we accl i nated the test fi sh to near $20^{\circ} \mathrm{C}$ The scal es were loose on the test fish and many of them becane descaled during accli mati on and transport: however, the test data are usef ul. The conditi on of the test $f i s h$ as a popul ation was not degraded by passage through the screen di versi on. Thi s concl usi on is based on the change of condi ti on bet ueen test and control popul ati ons. Data in Tabl e B. 17 are the resul ts of screening facility eval uations. Data in Table B. 18 are the esti nated ti nes for test fish to move through the Toppenish/Sat us Screen Facility. Descaling data from upriver hatchery-rel eased and native fish are presented in Table B.19.

Data from the Yapato Screens eval uati on indi cate that fish are saf el y di verted from the canal to the river. The eval uation of the potential for screen passage at Yapato i ndi cates that few fi sh pass through and over the screens: the esti mated number based on tests with fall chi nook sal mon fry is I ess than 2\% Data from the tests at the Yapato Screens are presented in Tabl es 8.20 through 8.24. 8.26 through 8.28. and 8. 30 through 8. 32. Data in Tables 8.20 are from the eval uations of the $i$ ncl i ned pl ane and nets used to capt ure fish at the Yapato Screens. The pl ane and nets safely collected fish. Data in Table 8.21 and 8.22 are eval uations of the condition of the test fish before rel ease in the canal. Fish were in good conditi on bef ore rel ease. Data in Tables 8.23 and 8.24 are the results of the screening facility eval uations. Table 8.26 presents the descaling data col I ected from upri ver nat i ve and hat chery sal noni ds capt ured duri ng the eval uation tests. Tables 8.27 and 8.51 presents data from a test of the fi sh return pi pe at the Yapato Screens. Tables 8.28. 8.32. and 8. 41 gi ve data used to esti mate the migration ti me through the screen facility for test fish. Tables 8.30. 8. 31. 8. 42. 8.43. and 8.44 gi ve the data from the screen integrity tests at the Yapato Screens.

Data from the Toppeni sh Creek Screens indi cate that fi sh are saf el y di verted from the canal to the river. Data are presented in Tabl es 8.33 through 8. 40. The data in Table 8.33 represent eval uation of the i ncl i ned pl ane. The plane collected fish without killing or descaling the fish. Data in Table 8.34 are eval uations of the condition of test fish before rel ease in the canal or screen facility. Test fish were in good condition bef ore thei $r$ rel ease. The data for the descaling eval uations are in Tabl es 8. 35 and 8. 38. Data in Table 8. 36 are the esti mated ti nes for test fi sh to nove through the Toppeni sh Creek Screen Facility. Data in Table 8. 39 and 40 are the results of the screen integrity eval uations. The screen 
integrity tests indi cate that I ess than $1 \%$ of test fish pass through or over the screens.

Data from Yestsi de Di tch i ndi cate that fi sh are not descal ed at the screen facility. Zero-age chi nook sal non can pass through, over or around the screens. Data are presented in Tables 8. 49. B. 50 and 8. 52 through B. 54. The data for the descal ing eval uati ons are in Table 8. 49. Data in Tabl e B.50 are the esti nated ti mes for test fi sh to move through Westsi de Ditch. Data in Table 8.52 through 6.54 are the results of the screen integrity eval uati ons. 
TABLE. Percent age of Coho Sal non Ororhynds kistch Snol ts Descal ed or KII ed During Tests of the I ncl i ned PI ane at Sunnysi de Canal Fi sh Screening Facility, Spring 1985

\begin{tabular}{|c|c|c|c|c|c|}
\hline \multirow[b]{2}{*}{$\begin{array}{c}\text { TEST } \\
\text { REPLI CATE } \\
\end{array}$} & \multicolumn{3}{|c|}{ NUMBER OF FI SH } & \multirow{2}{*}{$\begin{array}{r}\text { PERCENI } \\
\text { OESCALED } \\
\text { K LLED } \\
\end{array}$} & \multirow{2}{*}{$\begin{array}{c}95 \% \\
\text { OR CONFI DENCE } \\
\text { I NIERVAL }\end{array}$} \\
\hline & $\begin{array}{c}\text { PLACED ON } \\
\text { PLANE } \\
\end{array}$ & CAPTURED & $\begin{array}{c}\text { DESCALED OR } \\
\text { K LLED } \\
\end{array}$ & & \\
\hline 1 & 10 & 7 & 0 & 0 & 0.41 .0 \\
\hline 2 & 10 & 9 & 0 & 0 & 0.33 .6 \\
\hline 3 & 10 & 10 & 0 & D & 0.30 .8 \\
\hline 4 & 10 & 10 & 0 & 0 & 0.30 .8 \\
\hline 5 & 10 & 10 & 0 & 0 & 0.30 .8 \\
\hline 6 & 10 & 8 & 0 & 0 & 0.37 .0 \\
\hline 7 & 10 & 10 & D & D & 0.30 .8 \\
\hline 8 & 10 & 10 & $\underline{0}$ & $\underline{0}$ & $0-4.8$ \\
\hline TOTAL & 80 & 74 & 0 & 0 & $0-4.8$ \\
\hline
\end{tabular}

T A B L E . Percent age of St eel head Oxorhyndus mykss and Chi nook Sal non 0 tstantsda Snol ts Descal ed or KII ed Duri ng Tests of the Fyke Net at Sunnysi de Canal Fi sh Screening Facility, Spring 1985

\begin{tabular}{|c|c|c|c|c|c|}
\hline \multirow{2}{*}{$\begin{array}{l}\text { SPECI ES \& } \\
\text { TEST } \\
\text { REPLI CATE } \\
\end{array}$} & \multicolumn{3}{|c|}{ NUMBER OF FI SH } & PERCENI & \multirow{2}{*}{$\begin{array}{c}95 \% \\
\text { OR CONFI DENCE } \\
\text { INTERVAL } \\
\end{array}$} \\
\hline & $\begin{array}{l}\text { PLACED ON } \\
\text { PLANE }\end{array}$ & CAPTURED & $\begin{array}{c}\text { DESCALED OR } \\
\text { K LLED }\end{array}$ & $\begin{array}{r}\text { DESCALED } \\
\text { K LLED }\end{array}$ & \\
\hline St eel head 1 & 50 & 8 & 0 & 0 & 0.36 .0 \\
\hline St eel head 2 & 50 & 28 & 0 & 0 & D. 12.3 \\
\hline St eel head 3 & 55 & 21 & 0 & D & 0.16 .1 \\
\hline TOTAL & 155 & 57 & 0 & 0 & 0.6 .3 \\
\hline $\begin{array}{l}\text { Chi nook } \\
\text { Sal mon } 1\end{array}$ & 50 & 21 & 0 & 0 & 0.16 .1 \\
\hline
\end{tabular}


TABLE. Percent age of St eel head Ocorhynchs mykss Snol ts Descal ed Before Bei ng Used in Tests at Sunnysi de Canal Fi sh Screeni ng Facility, Spring 1985

\begin{tabular}{|c|c|c|c|c|}
\hline $\begin{array}{l}\text { TEST } \\
\text { SI TE }\end{array}$ & $\begin{array}{r}\text { NUMBE } \\
\text { EVALUATED }\end{array}$ & $\begin{array}{l}\text { FI SH } \\
\text { DESCALED }\end{array}$ & $\begin{array}{c}\text { PERCENI } \\
\text { DESCALED }\end{array}$ & $\begin{array}{c}95 \% \\
\text { CONFI DENCE } \\
\text { I NIERVAL }\end{array}$ \\
\hline $\begin{array}{c}\text { Tntermedi ate } \\
\text { Bypass }\end{array}$ & 24 & 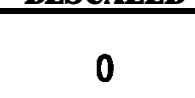 & 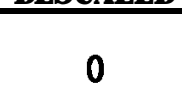 & 0-14. 3 \\
\hline $\begin{array}{c}\text { Ter mi nal } \\
\text { Bypass }\end{array}$ & 13 & 0 & 0 & 0.24 .7 \\
\hline $\begin{array}{c}\text { Trash } \\
\text { Rack }\end{array}$ & 19 & 0 & 0 & $0-17.7$ \\
\hline $\begin{array}{c}\text { Canal Head } \\
\text { Gat es }\end{array}$ & 20 & 0 & D & D. 16.8 \\
\hline
\end{tabular}

TABIF B.4. Percentage of Chi nook Sal non Ocorhyndhs tshanytscha Snol ts Descal ed Bef ore Bei ng Used in Tests at Sunnysi de Canal Fi sh Screening Facility, Spring 1985

\begin{tabular}{|c|c|c|c|c|}
\hline $\begin{array}{l}\text { TEST } \\
\text { SI TE }\end{array}$ & $\begin{array}{r}\text { NUMBE } \\
\text { EVALUATED }\end{array}$ & $\begin{array}{l}\text { FI SH } \\
\text { DESCALED }\end{array}$ & $\begin{array}{l}\text { PERCENI } \\
\text { DESCALED }\end{array}$ & $\begin{array}{c}95 \% \\
\text { CONFI DENCE } \\
\text { INTERVAL }\end{array}$ \\
\hline $\begin{array}{l}\text { Pri mary Fish } \\
\text { Ret urn Pi pe }\end{array}$ & 36 & 0 & 0 & $0-9.7$ \\
\hline $\begin{array}{l}\text { I nt er medi ate } \\
\text { Bypass }\end{array}$ & 20 & 0 & 0 & $0-16.8$ \\
\hline $\begin{array}{r}\text { Termi nal } \\
\text { Bypass }\end{array}$ & 20 & 0 & 0 & $0-16.8$ \\
\hline $\begin{array}{c}\text { Trash } \\
\text { Rack }\end{array}$ & 20 & 0 & 0 & $0-16.8$ \\
\hline $\begin{array}{c}\text { Canal Head } \\
\text { Gat es }\end{array}$ & 32 & 0 & D & $0-9.7$ \\
\hline
\end{tabular}


TABLE B. 5. Percentage of Steel head Otorhyndus nykiss Snol ts Descal ed or Killed in Each Test at Sunnysi de Canal Fi sh Screening Facility, Spring 1985

\begin{tabular}{|c|c|c|c|c|c|c|}
\hline \multirow{3}{*}{$\begin{array}{l}\text { RELEASE } \\
\text { SI TE } \\
\text { Pri mary Fi sh } \\
\text { Ret urn Pi pe }\end{array}$} & \multirow[b]{2}{*}{$\begin{array}{l}\text { TEST } \\
\text { ICATE }\end{array}$} & \multicolumn{3}{|c|}{ NUMBER OF FI SH } & \multirow{2}{*}{$\begin{array}{c}\text { PERCENT } \\
\text { DESCALED } \\
\text { OR K LLED }\end{array}$} & \multirow{2}{*}{$\begin{array}{c}95 \% \\
\text { CONFI DENCE } \\
\text { I NTERVAL }\end{array}$} \\
\hline & & RELEASED & CAPTURED & $\begin{array}{rr}\text { DESCALED } \\
\text { OR K LLED } \\
\end{array}$ & & \\
\hline & 1 & 50 & 8 & $\ldots \times-2$ & 0 & $0-36.8$ \\
\hline & 2 & 50 & 16 & 0 & 0 & $0-20.6$ \\
\hline & 3 & 72 & 6 & 0 & 0 & $0-45.9$ \\
\hline $\begin{array}{l}\text { I nt er medi ate } \\
\text { Bypass }\end{array}$ & 1 & 275 & 139 & 0 & 0 & $0-2.6$ \\
\hline $\begin{array}{l}\text { Termi nal } \\
\text { Bypass }\end{array}$ & 1 & 200 & 112 & 0 & 0 & $0-3.2$ \\
\hline Trash Rack & 1 & 500 & 126 & 0 & 0 & $0-2.9$ \\
\hline $\begin{array}{l}\text { Canal Head } \\
\text { Gates }\end{array}$ & 1 & 500 & 100 & 0 & 0 & $0-3.6$ \\
\hline
\end{tabular}

B. 6 
TABLE. Percent age of Chi nook Sal mon Ocorhynchus tshamytscha Smol ts Descal ed or Kiled in Each Test at Sunnysi de Canal Fi sh Screening Facility. Spring 1985

\begin{tabular}{|c|c|c|c|c|c|c|}
\hline \multirow[b]{2}{*}{$\begin{array}{l}\text { RELEASE } \\
\text { SI TE }\end{array}$} & \multirow[b]{2}{*}{$\begin{array}{c}\text { TEST } \\
\text { REPLI CATE } \\
\end{array}$} & \multicolumn{3}{|c|}{ NUMBER OF FI SH } & \multirow{2}{*}{$\begin{array}{c}\text { PERCENI } \\
\text { DESCALED } \\
\text { OR } \mathbf{K} \text { LLED }\end{array}$} & \multirow{2}{*}{$\begin{array}{l}95 \% \\
\text { CONFI DENCE } \\
\text { I NIERVAL } \\
\end{array}$} \\
\hline & & RELEASED & CAPTURED & $\begin{array}{r}\text { DESCALED } \\
\text { OR K LLED }\end{array}$ & & \\
\hline \multirow[t]{5}{*}{$\begin{array}{l}\text { Pri mary Fi sh } \\
\text { Ret urn Pi pe }\end{array}$} & 1 & 100 & 83 & 0 & 0 & $0.0-4.4$ \\
\hline & 2 & 100 & 64 & 2 & 3. 1 & $0.4-10.8$ \\
\hline & 3 & 100 & 75 & 0 & D & $0.0-4.8$ \\
\hline & 4 & 100 & 60 & 1 & 1. 7 & $0.0-8.9$ \\
\hline & 5 & 100 & 89 & 0 & 0 & $0.0-4.1$ \\
\hline \multirow[t]{5}{*}{$\begin{array}{l}\text { I nt er nedi ate } \\
\text { Bypass }\end{array}$} & 1 & 100 & 82 & 2 & 2.4 & $0.3-8.5$ \\
\hline & 2 & 100 & 95 & 0 & 0 & $0.0-3.8$ \\
\hline & 3 & 100 & 99 & 0 & 0 & $0.0-3.7$ \\
\hline & 4 & 100 & 95 & 2 & 2.1 & $0.3-7.4$ \\
\hline & 5 & 100 & 97 & 0 & D & $0.0-3.7$ \\
\hline \multirow[t]{5}{*}{$\begin{array}{l}\text { Ter mi nal } \\
\text { Bypass }\end{array}$} & 1 & 100 & 98 & 2 & 2 & $0.3-7.2$ \\
\hline & 2 & 100 & 96 & 1 & 1 & $0.0-5.7$ \\
\hline & 3 & 100 & 98 & 0 & 0 & $0.0-3.7$ \\
\hline & 4 & 100 & 98 & 3 & 3. 1 & $0.6-8.7$ \\
\hline & 5 & 92 & 86 & 1 & 1.2 & $0.0-6.3$ \\
\hline Trash Rack & 1 & 1000 & 856 & 20 & 2.3 & $1.4-3.6$ \\
\hline \multirow[t]{2}{*}{$\begin{array}{l}\text { Canal Head } \\
\text { Gates }\end{array}$} & 1 & 1000 & 729 & 6 & 0.8 & $0.2-1.6$ \\
\hline & 2 & 1000 & 725 & 21 & 2.9 & $2.0-4.7$ \\
\hline
\end{tabular}


I A8LF 8.7. Scal e Loss for Hat chery- Rel eased and Nati ve Fi sh Capt ured During Tests at Sunnysi de Canal Fi sh Screeni ng Facility, Spring 1985

\begin{tabular}{|c|c|c|c|c|}
\hline \multirow{3}{*}{$\begin{array}{c}\text { SPEC ES } \\
\text { Chi nook } \\
\text { Sal non }\end{array}$} & \multicolumn{2}{|c|}{ NUMBER OF FISH } & \multirow{2}{*}{$\begin{array}{c}\text { PERCENI } \\
\text { DESCALED } \\
\text { OR K LLED } \\
\end{array}$} & \multirow{2}{*}{$\begin{array}{c}95 \% \\
\text { CONFI DENCE } \\
\text { I NIERVAL }\end{array}$} \\
\hline & CAPTURED & OR K LLED & & \\
\hline & 214 & 9 & 4.2 & $2.0-7.7$ \\
\hline St eel head & 36 & 1 & 2.8 & $0.2-14.7$ \\
\hline
\end{tabular}

FAFIEE.8age of Chi nook Sal mon Oncorhynchus tshawytscha Smol ts Descal ed or Killed During Tests of the I nclined PI ane at Richland Canal Fi sh Screening Facility, Spring 1986

\begin{tabular}{|c|c|c|c|c|c|c|}
\hline \multirow{3}{*}{$\frac{\text { SPECI ES }}{\text { Spri ng }}$} & \multirow[b]{2}{*}{$\begin{array}{l}\text { TEST } \\
\text { REP. }\end{array}$} & \multicolumn{3}{|c|}{ NUMBER OF FI SH } & \multirow{2}{*}{$\begin{array}{c}\text { PERCENI } \\
\text { DESCALED } \\
\text { OR } \mathbf{K} \text { LLED }\end{array}$} & \multirow{2}{*}{$\begin{array}{c}95 \% \\
\text { CONFI DENCE } \\
\text { I NIERVAL }\end{array}$} \\
\hline & & RELEASED & CAPTURED & $\begin{array}{c}\text { DESCALED } \\
\text { OR } \mathrm{K} \text { LLED }\end{array}$ & & \\
\hline & 1 & 25 & 21 & 0 & 0 & $0-16.1$ \\
\hline & Control & & 19 & 0 & 0 & $0-17.7$ \\
\hline Fal I & 1 & 25 & 16 & 0 & 0 & $0-20.6$ \\
\hline & Control & & 20 & 0 & 0 & $0-16.8$ \\
\hline & 2 & 500 & 156 & 0 & 0 & $0-2.3$ \\
\hline
\end{tabular}

FAPIEeB.9.ge of Chi nook Sal mon Oncorhynchus tshawytscha Smol ts Descal ed or Killed During Tests of the Fyke Net at Richland Canal Fi sh Screeni ng Facil i ty, Spri ng 1986

\begin{tabular}{cccccc}
\hline $\begin{array}{c}\text { TEST } \\
\text { REPLI CATE }\end{array}$ & RELEASED & CAPTURED & $\begin{array}{c}\text { DESCALED } \\
\text { OR K LLED }\end{array}$ & $\begin{array}{c}\text { PERCENT } \\
\text { DESCALED } \\
\text { OR K LLED }\end{array}$ & $\begin{array}{c}\text { 95\% } \\
\text { CONFI DENCE } \\
\text { INTERVAL }\end{array}$ \\
\hline $1-$ I $^{(a)}$ & 50 & 26 & 0 & 0 & $0.0-13.2$ \\
L- control & 50 & 50 & 0 & 0 & $0.0-7.1$ \\
$1-H^{(b)}$ & 90 & 75 & 14 & 18.7 & $10.6-29.3$ \\
H control & 50 & 42 & 17 & 40.5 & $25.6-56.7$
\end{tabular}

(a) The $L$ desi gnati on i ndi cates tests at $0.6 \mathrm{~m}^{3} / \mathrm{s}$ fl ow through the fish ret urn pi pe.

(b) The $\mathrm{H}$ desi gnati on i ndi cates tests at $1.6 \mathrm{~m} / \mathrm{s}$ fl ow through the fi sh return pi pe. 
IABLE B.10. Percent age of Steel head Ocohynchs mykiss Smol ts Descal ed Before Being Used in Tests at Richland Canal Fi sh Screeni ng Facility, Spring 1986

\begin{tabular}{|c|c|c|c|c|c|}
\hline \multirow[b]{2}{*}{$\begin{array}{c}\text { TEST } \\
\text { REPLI CATE }\end{array}$} & \multicolumn{3}{|c|}{ NUMBER OF FISH } & \multirow{2}{*}{$\begin{array}{c}\text { PERCENT } \\
\text { DESCALED } \\
\text { OR K LLED }\end{array}$} & \multirow{2}{*}{$\begin{array}{c}95 \% \\
\text { CONFI DENCE } \\
\text { I NIERVAL }\end{array}$} \\
\hline & RELEASED & CAPTURED & $\begin{array}{c}\text { DESCALED } \\
\text { OR K LLED }\end{array}$ & & \\
\hline 1 & 100 & 100 & $\bar{D}$ & D & $0-3.6$ \\
\hline \multirow[t]{2}{*}{2} & 100 & 100 & 0 & 0 & $0-3.6$ \\
\hline & 101 & 101 & & & $0-5.4$ \\
\hline TOTAL & 301 & 301 & 1 & 0.3 & $0-1.8$ \\
\hline
\end{tabular}

TABLE B.11. Percentage of Chi nook Sal non Ocorhyndhs tshaytscha Smol ts Descal ed Before Bei ng Used in Tests at Richland Canal Fi sh Screeni ng Facility. Spring 1986

\begin{tabular}{cccccc}
\hline \multirow{2}{*}{$\begin{array}{c}\text { TEST } \\
\text { REPLI CATE }\end{array}$} & RELEASED & CAPTURED & $\begin{array}{c}\text { DESCALED } \\
\text { OR K LLED }\end{array}$ & $\begin{array}{c}\text { PERCENT } \\
\text { DESCALED } \\
\text { OR K LLED }\end{array}$ & $\begin{array}{c}95 \% \\
\text { CONFI DENCE } \\
\text { INTERVAL }\end{array}$ \\
\hline 1 & 100 & 100 & 0 & 0 & $0-3.6$ \\
2 & 100 & 100 & 0 & 0 & $0-3.6$ \\
3 & 102 & 102 & 0 & 0 & $0-3.6$ \\
\hline \multirow{2}{*}{ TOTAL } & 302 & 302 & 0 & 0 & $0-1.2$ \\
\hline
\end{tabular}

IABLE B.12. Descal ing and Mrtal ity Data from Rel ease and Capt ure Tests with Steel head Ocorhyndus mykiss Snol ts at Richland Canal Fi sh Screeni ng Facility, Spring 1986

\begin{tabular}{cccccc}
\hline \multirow{2}{*}{$\begin{array}{c}\text { TEST } \\
\text { REPLI CATE }\end{array}$} & RELEASED & CAPTUREO & $\begin{array}{c}\text { DESCALED } \\
\text { OR K LLED }\end{array}$ & $\begin{array}{c}\text { PERCENT } \\
\text { OESCLEO } \\
\text { OR K LLED }\end{array}$ & $\begin{array}{c}\text { 95\% } \\
\text { CONFI DENCE } \\
\text { INTIRVAL }\end{array}$ \\
\hline 1 & 200 & 129 & 1 & 0.8 & $0.2-4.2$ \\
2 & 200 & 132 & 2 & 1.5 & $0.2-5.4$ \\
3 & 200 & 102 & 1 & 1.1 & $0.3-2.8$ \\
\hline TOTAL & 600 & 363 & 4 & 1.1 & $0.3-2.8$ \\
\hline
\end{tabular}


TABLE B.13. Descal ing and Mrtality Data from Rel ease and Capt ure Tests wi th Spri ng Chi nook Sal non Oncorhynchus tshawytscha Snol ts at Richland Canal Fish Screeni ng Facility, Spring 1986

\begin{tabular}{|c|c|c|c|c|c|c|c|c|}
\hline \multirow{3}{*}{$\begin{array}{l}\text { TEST } \\
\text { SI TE }\end{array}$} & \multirow{3}{*}{$\begin{array}{l}\text { CAPTURE } \\
\text { METHOD }\end{array}$} & & & \multicolumn{3}{|c|}{ NUMBER OF FI SH } & \multirow{3}{*}{$\begin{array}{c}\text { PERCENT } \\
\text { DESCALED } \\
\text { OR K LLED }\end{array}$} & \multirow{3}{*}{$\begin{array}{c}95 \% \\
\text { CONFI DENCE } \\
\text { I NTERVAL }\end{array}$} \\
\hline & & \multicolumn{2}{|c|}{ FLOW } & & & DESCALED & & \\
\hline & & $\left(m^{3} / s\right)$ & $(c f s)$ & RELEASED & CAPTURED & OR K LLED & & \\
\hline Pi pe & Fyke(a) & 0.3 & 10 & 90 & 58 & 2 & 3.5 & $\begin{array}{cc}0.4 & -11.9\end{array}$ \\
\hline Pi pe & Fyke & 0.3 & 10 & 90 & 37 & 1 & 2.7 & $\begin{array}{ll}0.1 & -14.2\end{array}$ \\
\hline Pi pe & Fyke & 0.3 & 10 & 90 & 29 & 0 & 0.0 & $0.0-12.0$ \\
\hline TOTAL & & & & 270 & 124 & 3 & 2.4 & $0.5 \cdot 6.9$ \\
\hline Pi pe & Fyke & 0.6 & 10 & 90 & 75 & 14 & 18.7 & $\begin{array}{ll}10.6 & -29.3\end{array}$ \\
\hline Pi pe & E.S. (b) & 0.3 & 10 & 110 & 107 & 2 & 1.9 & $0.2 \cdot 6.6$ \\
\hline Pi pe & E.S. & 0.6 & 10 & 210 & 106 & 0 & 0.0 & $0.0 \cdot 3.4$ \\
\hline Trash Rack & & & & 200 & 186 & 2 & 1.1 & $0.1 \cdot 3.8$ \\
\hline Trash Rack & & & & 200 & 189 & 2 & 1.1 & $0.1 \cdot 3.8$ \\
\hline TOTAL & & & & 600 & 560 & 4 & 0.7 & $0.2-1.8$ \\
\hline
\end{tabular}

(a) Fyke, fyke net.

(b) E.S... el ect roshocker. 
IABLE B.14. Esti mated Ti me (h) to Catch $50 \%$ and $95 \%$ of Test Fi sh Capt ured at Richland Canal Fi sh Screeni ng Facility. Spring 1986

\begin{tabular}{|c|c|c|c|c|c|c|}
\hline \multirow[b]{2}{*}{ SPECI ES } & \multicolumn{3}{|c|}{ TI ME TO CATCH } & \multicolumn{2}{|c|}{ NUMBER OF FI SH } & \multirow{2}{*}{$\begin{array}{c}\text { PERCENT } \\
\text { CAPTURED }\end{array}$} \\
\hline & GROP & $50 \%$ & $90 \%$ & RELEASED & CAPTURED & \\
\hline St eel head & 1 & 18.0 & 52.5 & 200 & 129 & 64.5 \\
\hline St eel head & 2 & 21.0 & 48.0 & 200 & 134 & 67.0 \\
\hline St eel head & 3 & 29.0 & 54.5 & 200 & 102 & 51.0 \\
\hline $\begin{array}{l}\text { Sppri ng } \\
\text { Chi nook }\end{array}$ & 1 & 0.5 & 6.5 & 200 & 186 & 93.0 \\
\hline $\begin{array}{l}\text { Spri ng } \\
\text { Chi nook }\end{array}$ & 2 & 1.0 & 5. 0 & 200 & 188 & 94.0 \\
\hline $\begin{array}{l}\text { Sppri ng } \\
\text { Chi nook }\end{array}$ & 3 & 1.0 & 3. 5 & 200 & 185 & 92.5 \\
\hline $\begin{array}{c}\text { Fal I } \\
\text { Chi nook }\end{array}$ & 1 & 9.5 & 34. 5 & 1000 & 638 & 63.8 \\
\hline $\begin{array}{c}\text { Fal I } \\
\text { Chi nook }\end{array}$ & 2 & 8.5 & 32.0 & 1150 & 682 & 59.3 \\
\hline $\begin{array}{c}\text { Fal I } \\
\text { Chinook }\end{array}$ & 3 & 7. 0 & 31.0 & 1150 & 809 & 70.3 \\
\hline
\end{tabular}

TABLE B.15. Scal e Loss for Hatchery-Rel eased and Nati ve Fi sh Capt ured During Tests at Richland Canal Fi sh Screeni ng Faci I ity, Spring 1986

\begin{tabular}{|c|c|c|c|c|}
\hline SPECI ES & $\begin{array}{r}\text { NUM } \\
\text { CAPTURED }\end{array}$ & $\begin{array}{l}\text { FI SH } \\
\text { DESCALED } \\
\text { OR K LLED }\end{array}$ & $\begin{array}{c}\text { PERCENT } \\
\text { DESCALED } \\
\text { OR K LLED }\end{array}$ & $\begin{array}{c}95 \% \\
\text { CONFI DENCE } \\
\text { I NIERVAL }\end{array}$ \\
\hline $\begin{array}{c}\text { Chi nook } \\
\text { Sal non(a) }\end{array}$ & 64 & 3 & 4.7 & $1.0-11.0$ \\
\hline Coho Sal mon & 17 & 3 & 17. 7 & $3.8-48.0$ \\
\hline St eel head & 51 & 3 & 5.9 & $1.3-18.9$ \\
\hline
\end{tabular}

(a) Pri narily spring chi nook sal non ( $>10 \mathrm{~cm}$ FL) but i ncl udi ng some fal I chi nook sal mon ( $<10 \mathrm{~cm}$ FL). 
IABLE B.16. Percentage of Steel head Ocorhyndus mykiss Snol ts Descal ed Bef ore Bei ng Used in Tests at Toppeni sh/Sat us Canal Fi sh Screening Facility, Spring 1986

\begin{tabular}{cccccc}
\hline \multirow{2}{*}{$\begin{array}{c}\text { TEST } \\
\text { REPLI CATE }\end{array}$} & RELEASED & CAPTURED & $\begin{array}{c}\text { DESCALED } \\
\text { OR K LLED }\end{array}$ & $\begin{array}{c}\text { PERCENI } \\
\text { DESCALED } \\
\text { OR K LLED }\end{array}$ & $\begin{array}{c}\text { 95\% } \\
\text { CONFI DENCE } \\
\text { I NIERVAL }\end{array}$ \\
\hline 1 & 103 & 103 & 37 & 35.9 & $26.7-46.0$ \\
2 & 103 & 103 & 29 & 28.2 & $19.7-37.9$ \\
3 & 105 & 105 & 16 & 15.2 & $22.0-32.9$ \\
\hline TOTAL & 311 & 311 & 82 & 26.4 & $22.0-32.9$ \\
\hline
\end{tabular}

IABLE B.17. Descal ing and Mortal ity Data from Rel ease and Capt ure Tests with Steel head Ocorhyndus mykiss Smolts at Toppeni sh/ Sat us Canal Fi sh Screening Facility, Spring 1986

\begin{tabular}{|c|c|c|c|c|c|}
\hline \multirow[b]{2}{*}{$\begin{array}{c}\text { TEST } \\
\text { REPLI CATE }\end{array}$} & \multicolumn{3}{|c|}{ NUMBER OF FI SH } & \multirow{2}{*}{$\begin{array}{c}\text { PERCENT } \\
\text { DESCALED } \\
\text { OR K LLED }\end{array}$} & \multirow{2}{*}{$\begin{array}{c}95 \% \\
\text { CONFI DENCE } \\
\text { INTERVAL }\end{array}$} \\
\hline & RELEASED & CAPTURED & $\begin{array}{l}\text { DESCALED } \\
\text { OR K LLED }\end{array}$ & & \\
\hline 1 & 520 & 462 & 120 & 26.0 & 23. 1-31. 3 \\
\hline 2 & 520 & 463 & 102 & 22.0 & 19.4-27.1 \\
\hline 3 & 520 & 463 & 40 & 8. 6 & 6. 2-11. 6 \\
\hline TOTAL & 1560 & 1388 & 262 & 18.9 & 17.4-21.6 \\
\hline
\end{tabular}


TABLE B.L 8. Esti mated Ti me (h) to Catch $50 \%$ and $95 \%$ of Test Fi sh Capt ured at Toppeni sh/ Sat us Canal Fi sh Screening Facility. Spring 1986

\begin{tabular}{|c|c|c|c|c|c|c|}
\hline \multirow[b]{2}{*}{ SPECI ES } & \multicolumn{3}{|c|}{ TIME TO CATCH (h) } & \multicolumn{2}{|c|}{ NUMBER OF FI SH } & \multirow{2}{*}{$\begin{array}{l}\text { PERCENI } \\
\text { CAPTURED }\end{array}$} \\
\hline & GRP & $50 \%$ & $95 \%$ & RELEASED & CAPTURED & \\
\hline St eel head & 1 & 12.5 & 41 & 520 & 462 & 88.8 \\
\hline St eel head & 2 & 12 & 46. 5 & 520 & 464 & 89.2 \\
\hline St eel head & 3 & 10 & 42. 5 & 520 & 463 & 89.0 \\
\hline $\begin{array}{l}\text { Spri ng } \\
\text { Chi nook }\end{array}$ & 1 & 0.5 & 1. 5 & 360 & 356 & 98.9 \\
\hline $\begin{array}{l}\text { Spri ng } \\
\text { Chi nook }\end{array}$ & 2 & 0.5 & 1. 5 & 335 & 329 & 98. 2 \\
\hline $\begin{array}{l}\text { Spri ng } \\
\text { Chi nook }\end{array}$ & 3 & 0.5 & 1.5 & 335 & 314 & 93. 7 \\
\hline $\begin{array}{l}\text { Fal I } \\
\text { Chi nook }\end{array}$ & 1 & 0.5 & 0.5 & 1000 & 728 & 72.8 \\
\hline $\begin{array}{l}\text { Fal I } \\
\text { Chi nook }\end{array}$ & 2 & 0.5 & 0.5 & 1000 & 702 & 70.2 \\
\hline $\begin{array}{l}\text { Fal I } \\
\text { Chi nook }\end{array}$ & 3 & 0.5 & 0.5 & 460 & 330 & 71.7 \\
\hline
\end{tabular}

IABLE B.19. Scal e Loss for Hatchery-Rel eased and Nati ve Fi sh Capt ured During Tests at Toppeni sh/Sat us Canal Fi sh Screening Facility, Spring 1986

\begin{tabular}{|c|c|c|c|c|}
\hline \multirow[b]{2}{*}{ SPECI ES } & \multicolumn{2}{|c|}{ NUMBER OF FISH } & \multirow{2}{*}{$\begin{array}{c}\text { PERCENI } \\
\text { DESCALED } \\
\text { OR K LLED } \\
\end{array}$} & \multirow{2}{*}{$\begin{array}{c}95 \% \\
\text { CONFI DENCE } \\
\text { INTERVAL } \\
\end{array}$} \\
\hline & CAPTURED & $\begin{array}{l}\text { DESCALED } \\
\text { OR K LLED }\end{array}$ & & \\
\hline St eel head (I-age) & 20 & D & 0 & $0.0-16.8$ \\
\hline St eel head ( 0 age) & 69 & 0 & 0 & $0.0-05.2$ \\
\hline Coho Sal mon (I-age) & 29 & D & 0 & $0.0-12.0$ \\
\hline Chi nook Sal mon & 25 & 1 & 4 & $0.1-20.4$ \\
\hline
\end{tabular}


IABLE B.20. Percentage of Spring Chi nook Sal non Ocorhynchs tshaytscha and St eel head ocorhyndus mykss Snol ts Descal ed or K I I ed During Tests of the I ncl i ned PI ane at Uapato Canal Fi sh Screening Facility, Spring 1987

\begin{tabular}{|c|c|c|c|c|c|}
\hline \multirow[b]{2}{*}{$\frac{\text { SPEC ES }}{\text { St eel head }}$} & \multicolumn{2}{|c|}{ NUMER OF FI SH } & \multirow[b]{2}{*}{ DESCALED } & PERCENI & \multirow{2}{*}{$\begin{array}{c}95 \% \\
\text { CONFI DENCE } \\
\text { I NIERVAL }\end{array}$} \\
\hline & $\frac{\text { RELEASED }}{10}$ & $\frac{\text { CAPTURED }}{9}$ & & $\frac{\text { DESCALED }}{0}$ & \\
\hline St eel head & 10 & 9 & 0 & 0 & 0.33 .6 \\
\hline TOTAL & 20 & 18 & 0 & 0 & $0-17.7$ \\
\hline $\begin{array}{l}\text { Spri ng } \\
\text { Chi nook }\end{array}$ & 10 & 10 & 0 & 0 & 0.30 .8 \\
\hline $\begin{array}{l}\text { Spri ng } \\
\text { Chi nook }\end{array}$ & 10 & 10 & 0 & 0 & 0.30 .8 \\
\hline TOTAL & 20 & 20 & 0 & 0 & 0.16 .8 \\
\hline
\end{tabular}

IABLE B.21. Percentage of Steel head Oxorhyndhs mykiss Snol ts Descal ed Bef ore Bei ng Used in Tests at Uapato Canal Fi sh Screeni ng Facil ity, Spring 1987

\begin{tabular}{|c|c|c|c|c|c|}
\hline $\begin{array}{c}\text { TEST } \\
\text { REPLI CATE }\end{array}$ & $\begin{array}{l}\text { CANAL } \\
\text { FLOW } \\
\text { (CFS) } \\
\frac{800}{}\end{array}$ & $\begin{array}{c}\text { NUMBER } \\
\text { EXAMNED } \\
65\end{array}$ & $\begin{array}{c}\text { FI SH } \\
\text { DESCALED } \\
0\end{array}$ & $\begin{array}{c}\text { PERCENT } \\
\text { DESCALED } \\
0\end{array}$ & $\begin{array}{c}\text { 957 } \\
\text { CONFI DENCE } \\
\text { I NIERVAL } \\
0-5.5\end{array}$ \\
\hline 2 & 800 & 67 & 1 & 1.5 & $0.0-8.0$ \\
\hline 3 & 800 & 68 & 0 & 0 & $0-5.3$ \\
\hline TOTAL & & 200 & 1 & 0.5 & $0.0-2.8$ \\
\hline 1 & 2000 & 35 & 0 & 0 & $0-10.0$ \\
\hline 2 & 2000 & 32 & 0 & 0 & $0-10.9$ \\
\hline 3 & 2000 & 33 & 0 & 0 & 0.10 .6 \\
\hline TOTAL & & 100 & 0 & 0 & 0.3 .6 \\
\hline 1 & 2000 & 38 & 0 & 0 & D. 9.3 \\
\hline 2 & 2000 & 36 & 0 & 0 & $0-9.7$ \\
\hline 3 & 2000 & 26 & 0 & 0 & 0.13 .2 \\
\hline TOTAL & & 100 & 0 & 0 & $0-3.6$ \\
\hline TOTAL & & 400 & 1 & 0.3 & $0.0-1.4$ \\
\hline
\end{tabular}


IABLE B.22. Percentage of Spri ng Chi nook Sal mon Ocorhyndhs tshanytsda Snol ts That Uere Descal ed Before Being Used in Tests at Uapato Canal Fi sh Screeni ng Facilities. Spring 1987

\begin{tabular}{|c|c|c|c|c|c|}
\hline $\begin{array}{c}\text { TEST } \\
\text { REPLI CATE }\end{array}$ & $\begin{array}{l}\text { CANAL } \\
\text { FLOW } \\
\text { (cfs) } \\
800\end{array}$ & $\begin{array}{c}\text { NUMBEF } \\
\text { EXAM NED } \\
74\end{array}$ & $\begin{array}{c}\text { FI SH } \\
\text { DESCALED } \\
0\end{array}$ & $\begin{array}{c}\text { PERCENT } \\
\text { DESCALED } \\
0\end{array}$ & $\begin{array}{c}95 \% \\
\text { CONFI DENCE } \\
\text { I NIERVAL } \\
0.4 .86\end{array}$ \\
\hline 2 & 800 & 59 & D & 0 & 0.6 .06 \\
\hline 3 & 800 & 67 & 0 & 0 & 0.5 .36 \\
\hline TOTAL & & 200 & 0 & 0 & 0.1 .83 \\
\hline 1 & 2000 & 35 & 0 & 0 & $0-10.00$ \\
\hline 2 & 2000 & 35 & 0 & 0 & $0-10.00$ \\
\hline 3 & 2000 & 30 & 0 & 0 & $0-11.57$ \\
\hline TOTAL & & 100 & 0 & 0 & $0-3.62$ \\
\hline 1 & 2000 & 33 & 0 & 0 & 0.10 .58 \\
\hline 2 & 2000 & 28 & 0 & 0 & 0.12 .34 \\
\hline 3 & 2000 & 39 & 0 & 0 & o- 9.03 \\
\hline TOTAL & & 100 & 0 & 0 & $0-3.62$ \\
\hline TOTAL & & 400 & 0 & 0 & $0-0.92$ \\
\hline
\end{tabular}


IABLE B.23. Percentage of Steel head Oncorhynchus mykiss Snol ts Descal ed or KII ed in Each Test at Whpato Canal Fi sh Screening Facility, Spring 1987

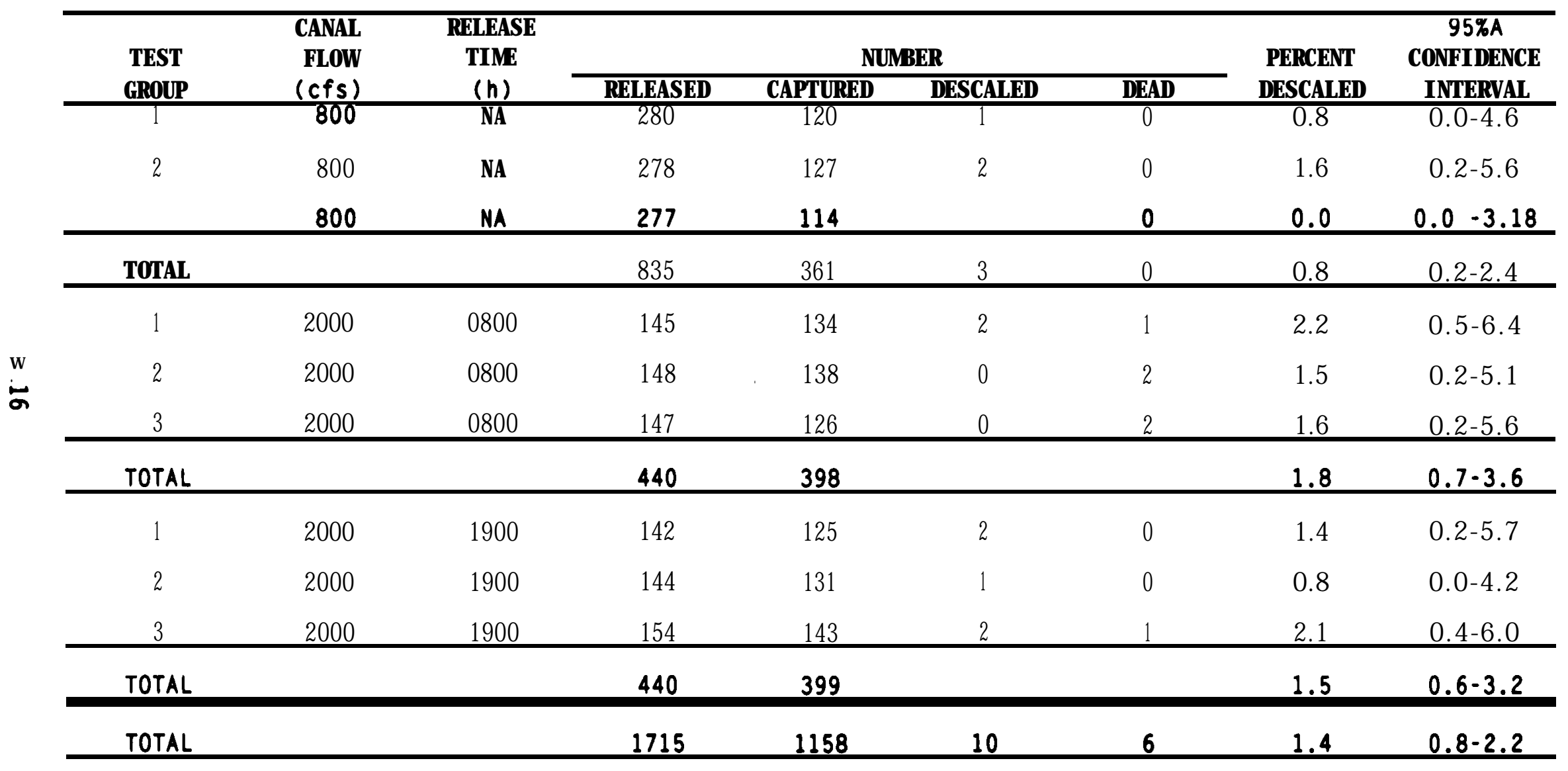


TABLE. Percent age of Spri ng Chi nook Sal mon Qcorhynhts tshanytscha Snol ts Descal ed or K I I ed i n Each Test at Whato Canal Fi sh Screeni ng Faci I ity, Spring 1987

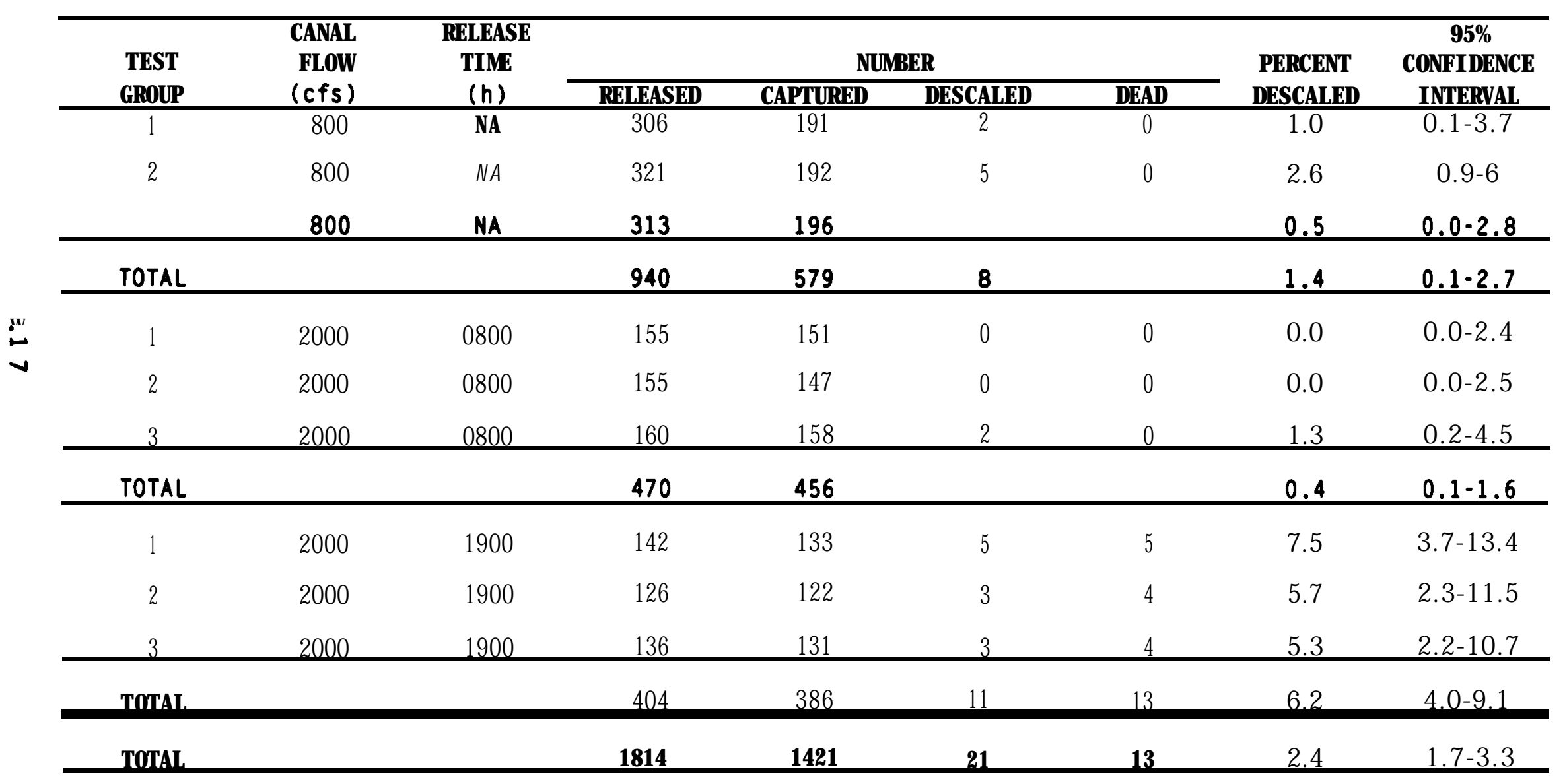


IABLE B.25. Scal e Loss for Hatchery-Rel eased and Nati ve Sal moni ds During Tests at Richland Canal Fi sh Screeni ng Facility, Spring 1987

\begin{tabular}{|c|c|c|c|c|}
\hline \multirow[b]{2}{*}{ SPECI ES } & \multicolumn{2}{|c|}{ NUMER } & \multirow{2}{*}{$\begin{array}{l}\text { PERCENT } \\
\text { DESCALED }\end{array}$} & $\begin{array}{c}\text { 95\% } \\
\text { CONFI DENCE } \\
\text { I NIERVAL }\end{array}$ \\
\hline & $\frac{\text { CAUG }}{11}$ & $\frac{\text { DESCALED }}{0}$ & & $\frac{\text { I NIERVAL }}{0-28.5}$ \\
\hline Spring Chi nook & 28 & 0 & 0.0 & $0-12.3$ \\
\hline Fal I Chi nook & 44 & $--(a)$ & $\ldots(a)$ & $\ldots$ (a) \\
\hline
\end{tabular}


IABLE B.26. Scal e Loss for Hatchery-Rel eased and Nati ve Sal moni ds Capt ured Duri ng Tests at hapato Canal Fi sh Screening Facility, Spring 1987

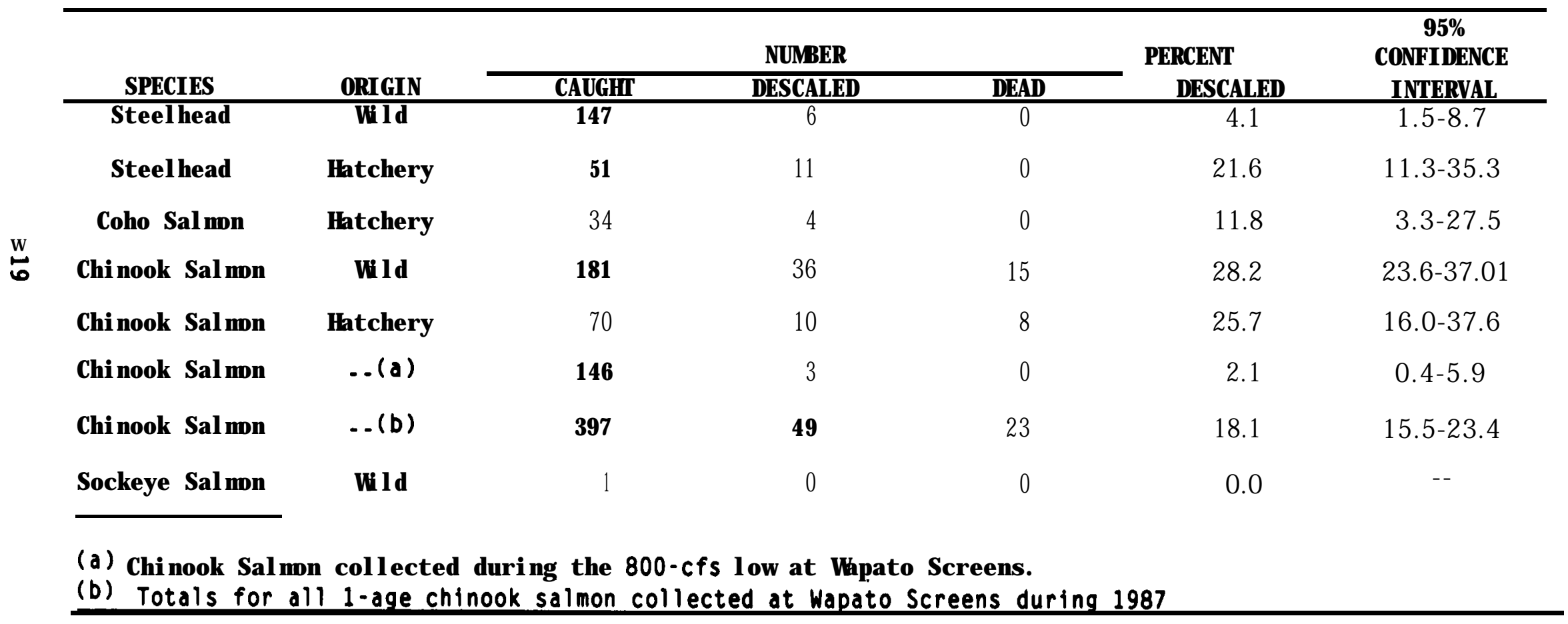


IABLE B.27. Percentage of Test Fi sh Descal ed or KII ed During Pi pe Tests at Whato Canal Fi sh Screening Facility, Spring 1987

\begin{tabular}{|c|c|c|c|c|c|}
\hline \multirow[b]{2}{*}{ SPECI ES } & \multicolumn{3}{|c|}{ NUMER } & \multirow{3}{*}{$\begin{array}{c}\begin{array}{c}\text { PERCENT } \\
\text { DESCALED }\end{array} \\
5.9\end{array}$} & \multirow{3}{*}{$\begin{array}{c}95 \% \\
\text { CONFI DENCE } \\
\text { I NIERVAL } \\
2.6-11.3\end{array}$} \\
\hline & RELEASED & CAPTURED & DESCALED & & \\
\hline Spring Chi nook & 150 & 135 & 8 & & \\
\hline Steel head & 100 & 65 & 1 & 1.5 & $0.0-5.5$ \\
\hline
\end{tabular}


IABLEB.28. Esti mated Ti me to Capt ure $50 \%$ and $95 \%$ of the Test Fi sh Rel eased at Whato Canal Fi sh Screening Facility, Spring 1987

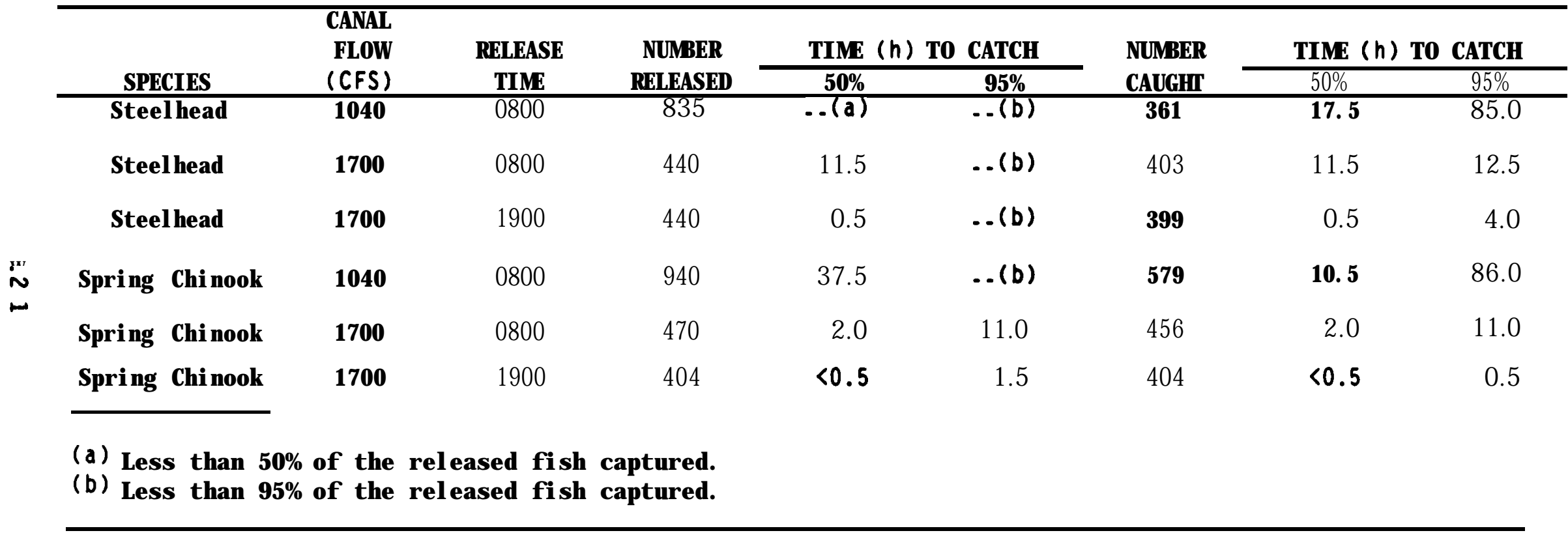


TABLE B.22. Capt ure Data for Fal I Chi nook Sal mon Ocorhyndhs tshanytscha Fry Rel eased at Richland Canal Fi sh Screening Facility, Spring 1987

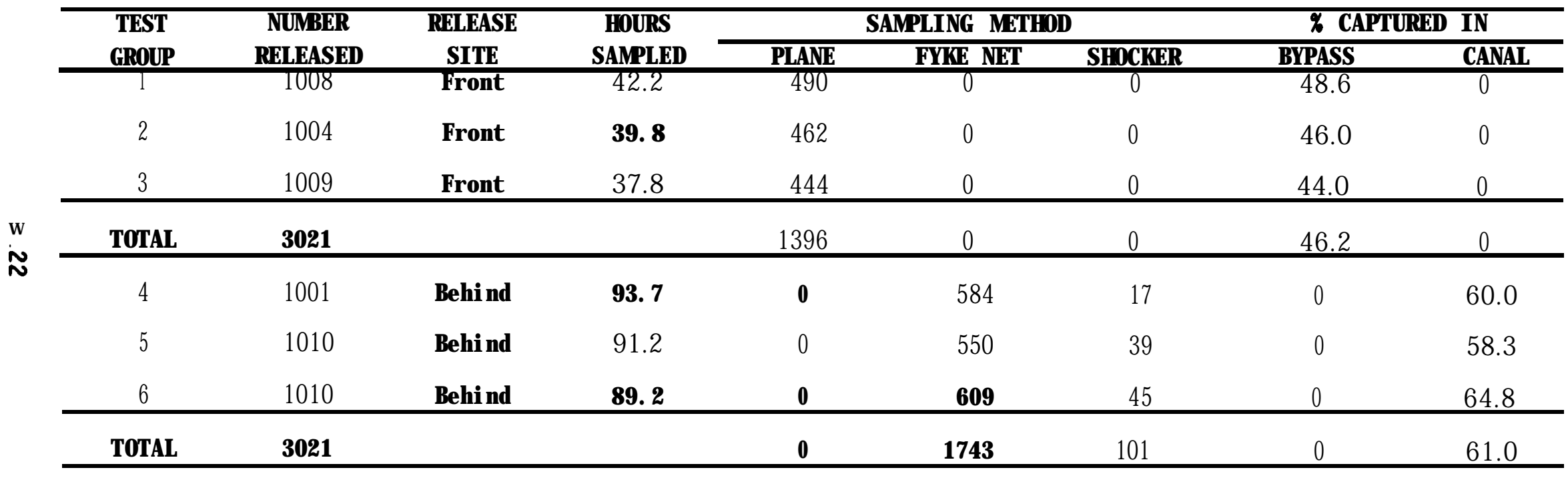


IABLE B.30. Capt ure Effici enci es of the I ncl i ned PI ane and Nets and Retenti on Efficiency of the Fyke Nets Used in Screen Integrity Tests at Whato Canal Fi sh Screening Facility, Spring 1987

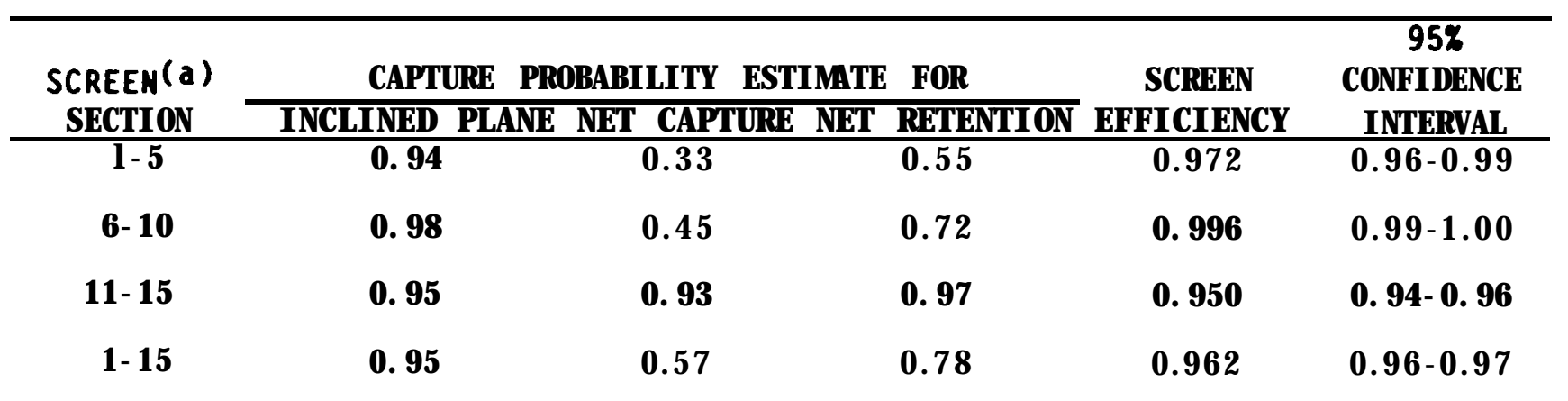

(a) The screens are nunbered from the upstream screen (NMBER 1) to the downst ream screen near est the separati on chanber (NUMBER 15). 
IABLE B.31. Capt ure Data for Fal I Chi nook Sal mon Cochyndhs tshanytscha Fry Rel eased Duri ng Screen I ntegrity Tests at Wapato Fi sh Screening Facility, Spring, 1987

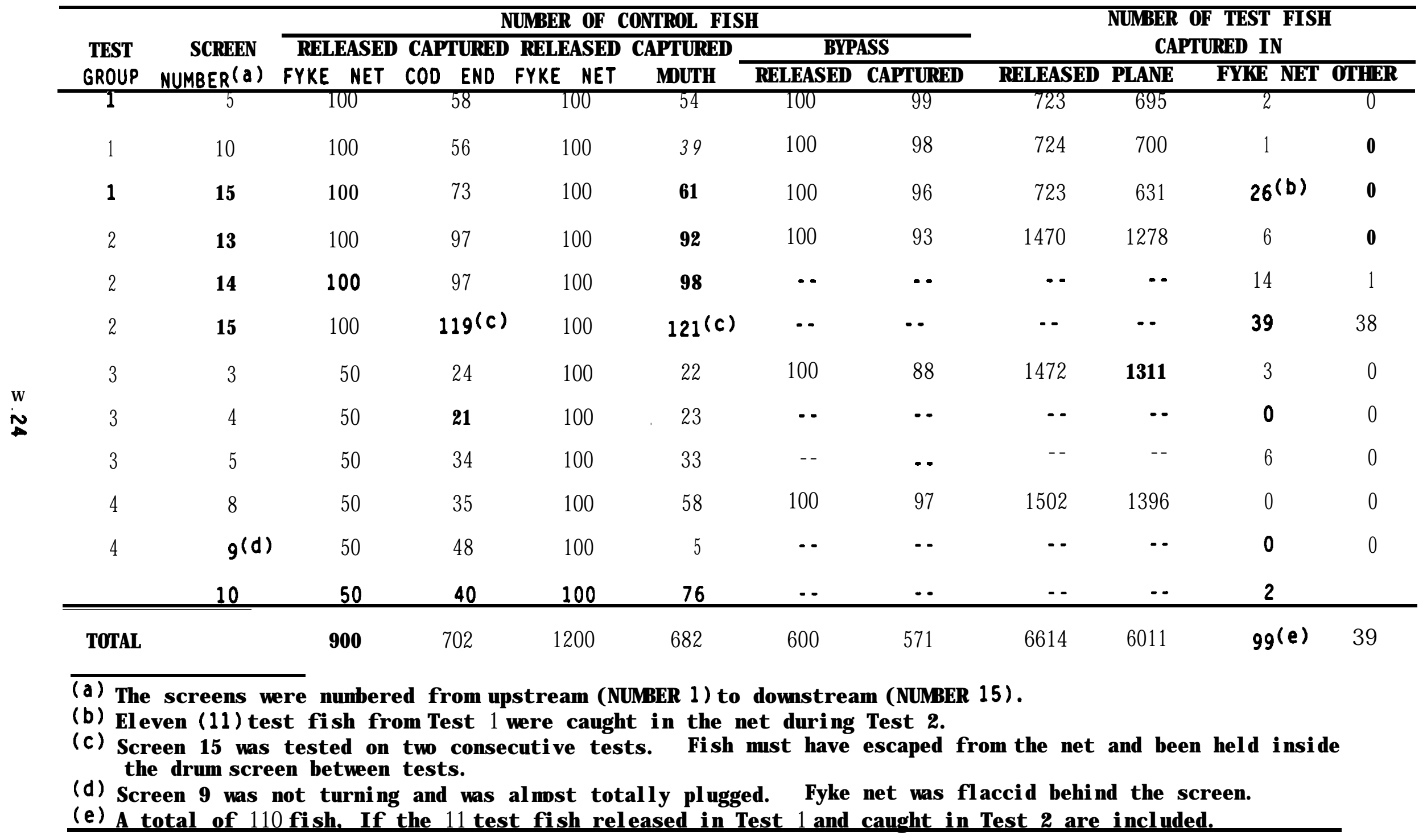


IABLE B.32. Esti mated Ti ne to Capt ure $50 \%$ and $95 \%$ of Fal I Chi nook Sal non OcorhyndustshanytsdaFry Rel eased in Screen I ntegrity Tests at Whato Canal Fi sh Screening Facility, Spring 1987

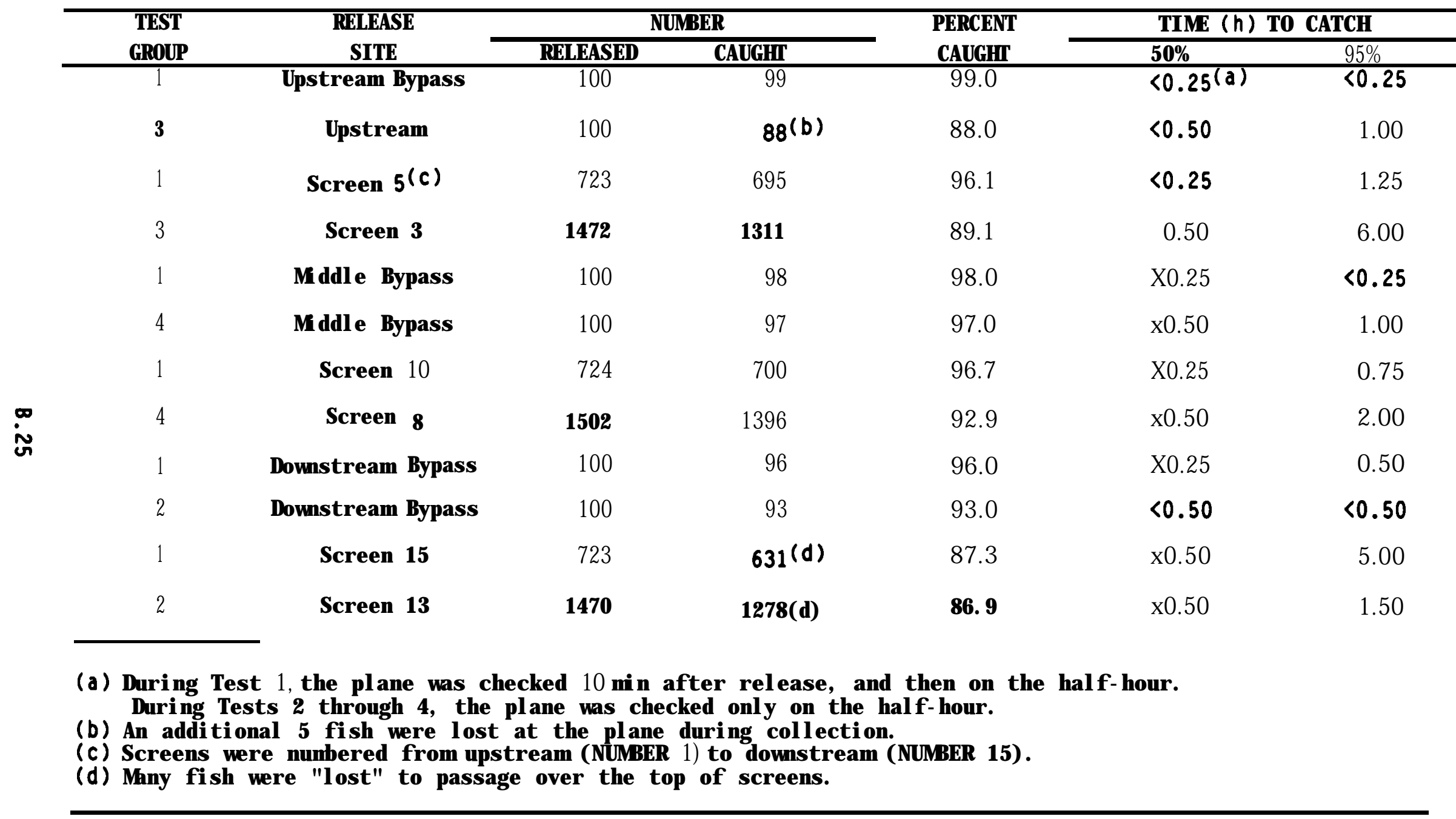


IABLE B.33. Percentage of Steel head Ocorhyndusmykiss Snol ts Descal ed or Killed in Tests of the I ncl ined PI ane at the Toppeni sh Creek Canal Fi sh Screening Facility, Spring 1988

\begin{tabular}{|c|c|c|c|c|c|}
\hline \multirow{2}{*}{$\begin{array}{c}\text { TEST } \\
\text { REPLI CATE }\end{array}$} & \multicolumn{3}{|c|}{ NUMBER OF FI SH } & \multirow{2}{*}{$\begin{array}{l}\text { PERCENT } \\
\text { DESCALED }\end{array}$} & \multirow{2}{*}{$\begin{array}{c}95 \% \\
\text { CONFI DENCE } \\
\text { I NIERVAL }\end{array}$} \\
\hline & RELEASED & CAPTURED & $\overline{\text { DESCALED }}$ & & \\
\hline 1 & 10 & 10 & 0 & 0.00 & $0-31$ \\
\hline 2 & 10 & 10 & 0 & 0.00 & 0- 31 \\
\hline 3 & 10 & 10 & 0 & 0.00 & 0- 31 \\
\hline 4 & 10 & 10 & 0 & 0.00 & 0- 31 \\
\hline 5 & 10 & 10 & 0 & 0.00 & 0- 31 \\
\hline 6 & 10 & 10 & 0 & 0.00 & $0-31$ \\
\hline 7 & 10 & 9 & 0 & 0.00 & 0- 34 \\
\hline 8 & 10 & 10 & 0 & 0.00 & 0- 31 \\
\hline 9 & 10 & 10 & 0 & 0.00 & 0- 31 \\
\hline 10 & 10 & 10 & 0 & 0.00 & 0- 31 \\
\hline TOTAL & 100 & 99 & 0 & 0.00 & $0-4$ \\
\hline
\end{tabular}

TABLE 8.34. Percent age of St eel head Ocorhynhusmyki ss Snol ts Descal ed Bef ore Bei ng Used in Tests at the Toppeni sh Creek Canal Fi sh Screeni ng Facility. Spring 1988

\begin{tabular}{|c|c|c|c|c|}
\hline \multirow{2}{*}{$\begin{array}{c}\text { TEST } \\
\text { REPLI CATE }\end{array}$} & \multicolumn{2}{|c|}{ NUMBER OF FI SH } & \multirow{2}{*}{$\begin{array}{r}\text { PERCENT } \\
\text { DESCALED }\end{array}$} & \multirow{2}{*}{$\begin{array}{c}95 \% \\
\text { CONFI DENCE } \\
\text { I NIERVAL }\end{array}$} \\
\hline & EXAM NED & DESCALED & & \\
\hline 1 & 70 & 0 & 0.00 & $0-5$ \\
\hline 2 & 70 & 0 & 0.00 & $0-5$ \\
\hline 3 & 70 & 0 & 0.00 & $0-5$ \\
\hline TOTAL & 210 & 0 & 0.00 & $0-2$ \\
\hline
\end{tabular}


IABLE B.35. Descaling and Mortality Data from Release and Capture Tests with Steelhead Oncorhynchus mykiss Smolts at the Toppenish Creek Fish Screening Facility. Spring 1988

\begin{tabular}{|c|c|c|c|c|c|c|c|}
\hline \multirow{2}{*}{$\begin{array}{l}\text { CANAL } \\
\text { FLOH } \\
\text { (Cfs) } \\
\end{array}$} & \multicolumn{4}{|c|}{ NUMBER } & \multicolumn{2}{|c|}{ PERCENT } & \multirow{2}{*}{$\begin{array}{c}95 \% \\
\text { CONFIDENCE } \\
\text { INTERVAL }\end{array}$} \\
\hline & RELEASED & CAPTURED & DESCALED & DEAD & CAPTURED & DESCALED & \\
\hline $\begin{array}{l}20 \\
50 \\
50\end{array}$ & $\begin{array}{l}250 \\
255 \\
250\end{array}$ & $\begin{array}{l}144 \\
199 \\
196\end{array}$ & $\begin{array}{l}0 \\
1 \\
0\end{array}$ & $\begin{array}{l}0 \\
0 \\
0\end{array}$ & $\begin{array}{l}57.6 \\
78.0 \\
78.4\end{array}$ & $\begin{array}{l}0.00 \\
0.50 \\
0.00\end{array}$ & $\begin{array}{l}0-2 \\
0-3 \\
0-2\end{array}$ \\
\hline Total & 755 & 539 & 1 & 0 & 71.4 & 0.19 & $0-1$ \\
\hline \multicolumn{2}{|c|}{ Wild Fish } & 462 & 1 & 0 & - & 0.22 & $0-1$ \\
\hline
\end{tabular}

IABLE B.36. Estimated Time to Capture $50 \%$ of Steelhead Oncorhynchus mykiss Smolts Released in Descaling Tests at Toppenish Creek Fish Screening Facility. Spring 1988

\begin{tabular}{lccccc}
\hline CANAL & \multicolumn{2}{c}{ NUMBER } & & PERCENT & TIME $(h)$ TO CATCH \\
\cline { 2 - 3 } FLOW & RELEASED & CAUGHT & & CAUGHT & $50 \%$ \\
\hline \multirow{2}{*}{20 cfs } & 250 & 144 & & $57.6(a)$ & 39.0 \\
50 cfs & 255 & 199 & & 78.0 & 16.0 \\
50 cfs & 250 & 196 & 78.4 & 14.0
\end{tabular}

(a) Inclined plane was removed for $2 \mathrm{~h}$ when canal flow was changed from 20 cfs to 50 cfs. Some fish from Test Group 1 may have moved out of the screen forebay during this period. which may have contributed to the lower percent caught for Test Group 1.

IABLE B.37. Estimated Time to Capture $50 \%$ of Rainbow Trout Oncorhynchus mykiss Fry Released in Screen Integrity Tests at Toppenish Creek Fish Screening Facility. Spring 1988

\begin{tabular}{|c|c|c|c|c|}
\hline $\begin{array}{l}\text { TEST } \\
\text { GROUP }\end{array}$ & RELEASED & $\frac{\text { BER }}{\text { CAUGHT }}$ & $\begin{array}{l}\text { PERCENT } \\
\text { CAUGHT }\end{array}$ & $\begin{array}{c}\text { TIME (h) TO CATCH } \\
50 \%\end{array}$ \\
\hline $\begin{array}{l}1 \\
2 \\
3\end{array}$ & $\begin{array}{l}1024 \\
1024 \\
1025\end{array}$ & $\begin{array}{l}868 \\
724 \\
781\end{array}$ & $\begin{array}{l}84.8 \\
70.7 \\
76.2\end{array}$ & $\begin{array}{l}4.0 \\
9.0 \\
4.0\end{array}$ \\
\hline
\end{tabular}


IABLE B.38. Percent age of Steel head Ocorhynchs myki ss Snol ts Descal ed in Pi pe Tests at the Toppeni sh Creek Fish Screening Facility, Spring 1988

\begin{tabular}{|c|c|c|c|c|c|}
\hline \multirow{2}{*}{$\begin{array}{l}\text { TEST } \\
\text { GROP }\end{array}$} & \multicolumn{3}{|c|}{ NMBBER of FI SH } & \multirow{2}{*}{$\begin{array}{l}\text { PERCENT } \\
\text { DESCALED }\end{array}$} & \multirow{2}{*}{$\begin{array}{c}95 \% \\
\text { CONFI DENC } \\
\text { I NIERVAL }\end{array}$} \\
\hline & RELEASED & CAPTURED & DESCALED & & \\
\hline $\begin{array}{c}1 \\
2 \\
3 \\
4 \\
5 \\
6 \\
7 \\
8 \\
9 \\
10 \\
11 \\
12 \\
13\end{array}$ & $\begin{array}{l}10 \\
10 \\
10 \\
10 \\
10 \\
10 \\
10 \\
10 \\
10 \\
10 \\
10 \\
10 \\
10\end{array}$ & $\begin{array}{l}\text { (a) } \\
\text { (a) } \\
\text { (a) } \\
\text { (a) } \\
\text { (a) } \\
\text { (a) } \\
\text { (a) } \\
\text { (a) } \\
\text { (a) } \\
\text { (a) } \\
\text { (a) } \\
\text { (a) } \\
\text { (a) }\end{array}$ & $\begin{array}{l}0 \\
0 \\
0 \\
0 \\
0 \\
0 \\
0 \\
0 \\
0 \\
0 \\
0 \\
0 \\
0\end{array}$ & $\begin{array}{l}\overline{-} \\
\overline{-} \\
\overline{-} \\
\overline{-}\end{array}$ & 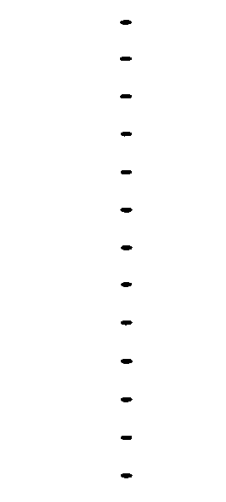 \\
\hline Total & 130 & 106 & 0 & 0.0 & $0-3$ \\
\hline
\end{tabular}

(a) Groups of ten fish were rel eased at the head of the fish return pi pe every 3 to $6 \mathrm{~min}$. We were not able to determi ne capt ure or descal ing rates for i ndi vidual rel ease groups, because sampling at the end of the pi pe was conti nuous. 
IABLE B.39. Capture Data for Rainbow Trout Oncorhynchus mykiss Fry Released During Screen Integrity Tests at the Toppenish Creek Fish Screening Facility. Spring 1988

\begin{tabular}{|c|c|c|c|c|c|c|c|c|c|}
\hline \multirow{3}{*}{$\begin{array}{l}\text { TEST } \\
\text { GROUP }\end{array}$} & \multicolumn{5}{|c|}{ NUMBER OF CONTROL FISH } & \multicolumn{4}{|c|}{ NUMBER OF TEST FISH } \\
\hline & SCREEN & RELEA & CAPTURED & RELEASE & CAPTURED & \multirow{3}{*}{ 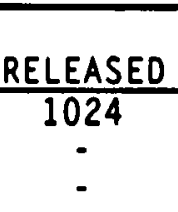 } & \multicolumn{3}{|c|}{ CAPTURED IN } \\
\hline & NUMBER & \multicolumn{2}{|c|}{ FYKE NET } & \multicolumn{2}{|c|}{ PLANE } & & PLANE & FYKE NET & OTHER \\
\hline $\begin{array}{l}1 \\
1 \\
1\end{array}$ & $\begin{array}{l}1 \\
2 \\
3\end{array}$ & $\begin{array}{l}100 \\
100 \\
100\end{array}$ & $\begin{array}{l}36 \\
66 \\
39\end{array}$ & $\begin{array}{c}100 \\
:\end{array}$ & $\begin{array}{c}100 \\
- \\
-\end{array}$ & & $\begin{array}{c}868 \\
- \\
-\end{array}$ & $\begin{array}{l}1 \\
0 \\
0\end{array}$ & 2 \\
\hline $\begin{array}{l}2 \\
2 \\
2\end{array}$ & $\begin{array}{l}1 \\
2 \\
3\end{array}$ & $\begin{array}{l}100 \\
100 \\
100\end{array}$ & $\begin{array}{l}63 \\
54 \\
58\end{array}$ & 100 & $\begin{array}{l}96 \\
-\end{array}$ & $\begin{array}{c}1024 \\
- \\
-\end{array}$ & $\begin{array}{l}724 \\
- \\
-\end{array}$ & $\begin{array}{l}1 \\
0 \\
3\end{array}$ & $\begin{array}{l}0 \\
.\end{array}$ \\
\hline $\begin{array}{l}3 \\
3 \\
3 \\
\end{array}$ & $\begin{array}{l}1 \\
2 \\
3\end{array}$ & $\begin{array}{l}100 \\
100 \\
100\end{array}$ & $\begin{array}{l}80 \\
75 \\
51\end{array}$ & $\begin{array}{c}100 \\
- \\
-\end{array}$ & $\begin{array}{c}100 \\
- \\
-\end{array}$ & $\begin{array}{c}1025 \\
- \\
-\end{array}$ & $\begin{array}{l}781 \\
- \\
-\end{array}$ & $\begin{array}{l}0 \\
0 \\
6\end{array}$ & $\begin{array}{l}4 \\
- \\
-\end{array}$ \\
\hline & & 900 & 522 & 300 & 296 & 3073 & 2373 & 11 & 6 \\
\hline
\end{tabular}


IABLE B.40. Capture Efficiency of the Inclined Plane and Fyke Nets Used During Screen Integrity Tests at the Toppenish Creek Fish Screening Facility. Spring 1988

\begin{tabular}{|c|c|c|c|c|c|}
\hline \multicolumn{2}{|c|}{ SCREEN } & \multicolumn{2}{|c|}{$\begin{array}{l}\text { CAPTURE PROBABILITY ESTIMATE } \\
\begin{array}{l}\text { INCLINED PLANE } \\
\text { FYKE NET }\end{array}\end{array}$} & $\begin{array}{l}\text { SCREEN } \\
\text { EFFICIENCY }\end{array}$ & $\begin{array}{l}95 \% \\
\text { CONFIDENCE } \\
\text { INTERVAL }\end{array}$ \\
\hline & $\begin{array}{l}1 \\
2 \\
3\end{array}$ & $\begin{array}{l}0.987 \\
0.987 \\
0.987 \\
0.966\end{array}$ & $\begin{array}{l}0.597 \\
0.650 \\
0.493 \\
0.580\end{array}$ & $\begin{array}{l}0.999 \\
1.000 \\
0.992 \\
0.966\end{array}$ & $\begin{array}{l}1.00-1.00 \\
1.00-1.00 \\
1.00-1.00 \\
0.95-0.98\end{array}$ \\
\hline ווגA & Screens & 0.987 & 0.580 & 0.991 & $0.99-1.00$ \\
\hline (a) & \multicolumn{5}{|c|}{$\begin{array}{l}\text { During the tests. } 37 \text { control fish placed in the fyke nets were caught } \\
\text { on the inclined plane. Assuming the } 37 \text { fish were test fish that } \\
\text { passed from the forebay to the area behind the screens. we calculated } \\
\text { a "worst case" screen efficiency of } 0.97( \pm 0.015) \text {. }\end{array}$} \\
\hline
\end{tabular}

IABLE B.41. Estimated Time to Capture $50 \%$ of Fall Chinook Salmon Oncorhynchus tshawytscha Fry Released in Screen Integrity Tests at the Wapato Fish Screening Facility. Spring 1988

\begin{tabular}{|c|c|c|c|c|c|}
\hline \multirow{2}{*}{$\begin{array}{l}\text { TEST } \\
\text { GROUP }\end{array}$} & \multirow[b]{2}{*}{ SCREENS } & \multicolumn{2}{|c|}{ NUMBER } & \multirow{2}{*}{$\begin{array}{l}\text { PERCENT } \\
\text { CAUGHT } \\
\end{array}$} & \multirow{2}{*}{$\begin{array}{c}\text { TIME (h) TO CATCH } \\
50 \%\end{array}$} \\
\hline & & RELEASED & CAUGHT & & \\
\hline $\begin{array}{l}1 \\
1 \\
1 \\
2 \\
3 \\
4\end{array}$ & $\begin{array}{c}5 \\
10 \\
15 \\
13-15 \\
3-5 \\
15\end{array}$ & $\begin{array}{l}1044 \\
1041 \\
1042 \\
1041 \\
1028 \\
1039\end{array}$ & $\begin{array}{l}775 \\
816 \\
535 \\
620 \\
675 \\
959\end{array}$ & $\begin{array}{l}74.2 \\
78.4 \\
51.3 \\
59.6 \\
65.7 \\
92.3\end{array}$ & $\begin{array}{l}6.5 \\
7.0 \\
7.5 \\
4.5 \\
0.5 \\
1.0 \\
\end{array}$ \\
\hline
\end{tabular}


IABLE B.42. Capture Data for Fall Chinook Salmon Fry Oncorhynchus tshawytscha Released During Screen Integrity Tests at the Wapato Canal Fish Screening Facility. Spring 1988

\begin{tabular}{|c|c|c|c|c|c|c|c|c|c|c|c|}
\hline \multirow{2}{*}{$\begin{array}{l}\text { TEST } \\
\text { GROUP }\end{array}$} & \multirow{2}{*}{$\begin{array}{l}\text { SCREEN } \\
\text { NUMBER } \\
\end{array}$} & \multicolumn{6}{|c|}{ NUMBER OF CONTROL FISH } & \multicolumn{4}{|c|}{$\begin{array}{c}\text { NUMBER OF TEST FISH } \\
\text { CAPTURED IN }\end{array}$} \\
\hline & & FYKE NET & COD END & FYKE & T MOUTH & \multicolumn{2}{|c|}{ PLANE } & RELEASED & PLANE & FYKE NET & OTHER \\
\hline $\begin{array}{l}1 \\
1 \\
1\end{array}$ & $\begin{array}{c}5 \\
10 \\
15\end{array}$ & $\begin{array}{l}50 \\
50 \\
50\end{array}$ & $\begin{array}{l}35 \\
45 \\
39\end{array}$ & $\begin{array}{l}100 \\
100 \\
100\end{array}$ & $\begin{array}{l}68 \\
95 \\
87\end{array}$ & $\begin{array}{l}100 \\
100 \\
100\end{array}$ & $\begin{array}{l}85 \\
77 \\
71\end{array}$ & $\begin{array}{l}1044 \\
1041 \\
1042\end{array}$ & $\begin{array}{l}775 \\
816 \\
535\end{array}$ & $\begin{array}{c}5 \\
2 \\
24\end{array}$ & $\begin{array}{l}0 \\
0 \\
1\end{array}$ \\
\hline $\begin{array}{l}2 \\
2 \\
2\end{array}$ & $\begin{array}{l}13 \\
14 \\
15\end{array}$ & $\begin{array}{l}50 \\
50 \\
50\end{array}$ & $\begin{array}{l}44 \\
46 \\
49\end{array}$ & $\begin{array}{l}100 \\
100 \\
100\end{array}$ & $\begin{array}{l}90 \\
90 \\
97\end{array}$ & $\begin{array}{c}100 \\
-\end{array}$ & $\begin{array}{r}76 \\
- \\
-\end{array}$ & $\begin{array}{c}1041 \\
\vdots\end{array}$ & $\begin{array}{c}620 \\
- \\
-\end{array}$ & $\begin{array}{l}2 \\
0 \\
4\end{array}$ & $\begin{array}{c}0 \\
0 \\
41\end{array}$ \\
\hline $\begin{array}{l}3 \\
3 \\
3\end{array}$ & $\begin{array}{l}3 \\
4 \\
5\end{array}$ & $\begin{array}{l}50 \\
50 \\
50\end{array}$ & $\begin{array}{l}47 \\
42 \\
46\end{array}$ & $\begin{array}{l}100 \\
100 \\
100\end{array}$ & $\begin{array}{l}78 \\
84 \\
87\end{array}$ & 100 & $\begin{array}{r}76 \\
- \\
-\end{array}$ & $\begin{array}{c}1028 \\
- \\
-\end{array}$ & $\begin{array}{c}675 \\
- \\
-\end{array}$ & $\begin{array}{l}0 \\
0 \\
1\end{array}$ & $\begin{array}{l}0 \\
0 \\
0\end{array}$ \\
\hline 4 & $\frac{15}{\operatorname{tal}}$ & $\frac{50}{500}$ & $\frac{44}{437}$ & $\frac{100}{900}$ & $\frac{95}{871}$ & $\frac{100}{600}$ & $\frac{96}{481}$ & $\frac{1039}{6235}$ & $\frac{959}{4380}$ & $\frac{5}{43}$ & $\frac{1}{43}$ \\
\hline
\end{tabular}


IABLE B.43. Capture Efficiency of the Inclined Plane and Nets and Retention Efficiency for Fyke Nets Used During Screen Integrity Tests at the Wapato Canal Fish Screening Facility. Spring 1988

\begin{tabular}{|c|c|c|c|c|c|}
\hline \multirow[b]{2}{*}{$\begin{array}{l}\text { SCREEN } \\
\text { SECTION (A) }\end{array}$} & \multicolumn{3}{|c|}{ PROBABILITY ESTIMATE } & \multirow[b]{2}{*}{$\begin{array}{l}\text { SCREEN } \\
\text { EFFICIENCY }\end{array}$} & \multirow{2}{*}{$\begin{array}{c}95 \% \\
\text { CONFIDENCE } \\
\text { INTERVAL }\end{array}$} \\
\hline & $\begin{array}{l}\text { PLANE } \\
\text { CAPTURE }\end{array}$ & $\begin{array}{l}\text { NET } \\
\text { CAPTURE }\end{array}$ & $\begin{array}{l}\text { NET } \\
\text { RETENTION }\end{array}$ & & \\
\hline $\begin{array}{c}1-5 \\
6-10 \\
11-15 \\
15 \\
1-15\end{array}$ & $\begin{array}{l}0.805 \\
0.770 \\
0.810 \\
0.960 \\
0.802\end{array}$ & $\begin{array}{l}0.793 \\
0.950 \\
0.918 \\
0.950 \\
0.968\end{array}$ & $\begin{array}{l}0.850 \\
0.900 \\
0.888 \\
0.880 \\
0.874\end{array}$ & $\begin{array}{l}0.995 \\
0.998 \\
0.984 \\
0.994 \\
0.991\end{array}$ & $\begin{array}{l}0.99-1.00 \\
0.99-1.00 \\
0.98-0.99 \\
0.99-1.00 \\
0.99-1.00\end{array}$ \\
\hline
\end{tabular}

(a) The screens are numbered from the upstream screen (NUMBER 1) to the downstream screen nearest the separation chamber (NUMBER 15).

IABLE B.44. Capture Data fron Fyke Nets Behind Selected Screens at the Wapato Canal Fish Screening Facility After the Release of Yakima Indian Nation (YIN) Fall Chinook Salmon Oncorhynchus tshawytscha from Net Pens. in the Wapato Screen Forebay. Spring 1988

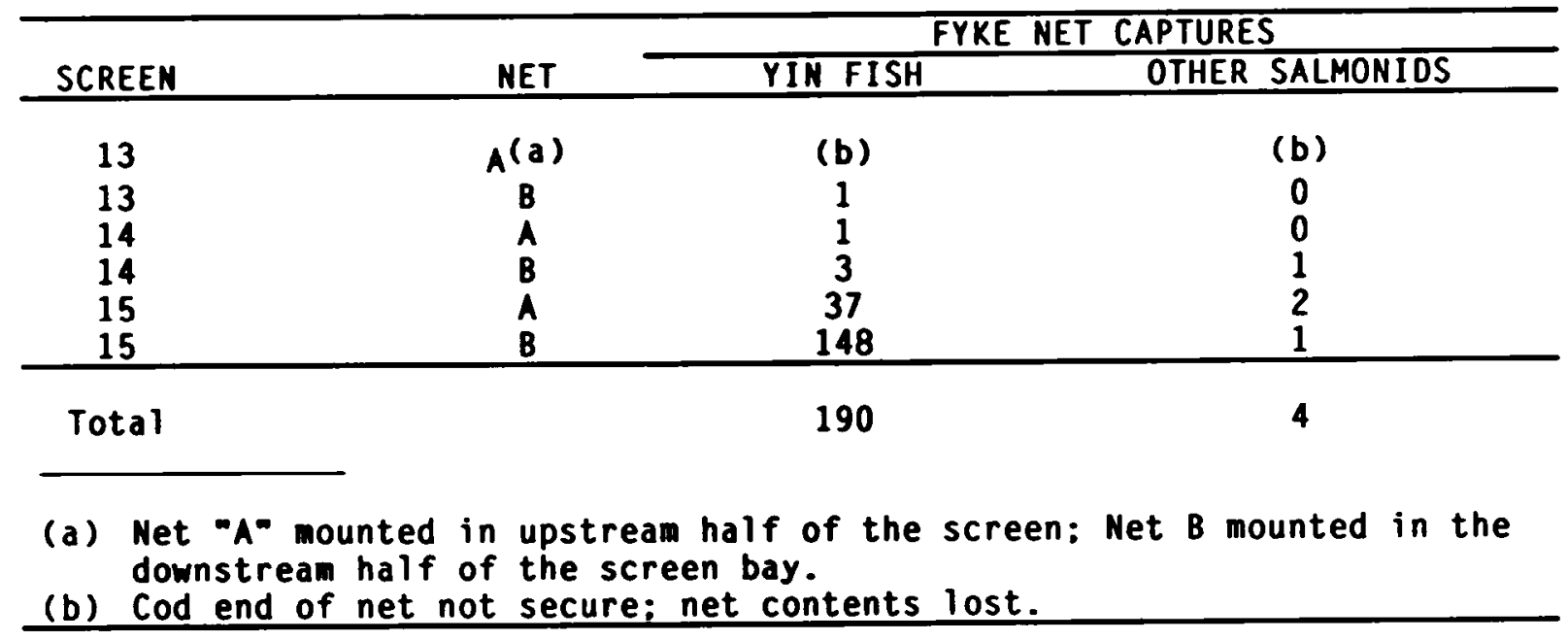


TABLE B.45. Estimated Time to Capture $50 \%$ of Fall Chinook Oncorhynchus tshawytscha Fry Released in Screen Integrity Tests at the Sunnyside Fish Screening Facility. Spring 1988

\begin{tabular}{ccccc}
\hline \multirow{2}{*}{$\begin{array}{c}\text { TEST } \\
\text { GROUP }\end{array}$} & \multicolumn{2}{c}{ NUMBER } & $\begin{array}{c}\text { PERCENT } \\
\text { CAUGHT }\end{array}$ & TIME $(h)$ TO CATCH \\
\cline { 2 - 5 } $50 \%$ \\
\cline { 2 - 5 } & RELEASED & CAUGHT & & \\
1 & & & & 1.0 \\
2 & 1045 & 746 & 71.4 & 1.0 \\
3 & 1047 & 791 & 75.5 & $<0.5$ \\
4 & 1047 & 891 & 85.1 & $<0.5$ \\
\hline
\end{tabular}


IABLE B.46. Capt ure Data for Fal I Chi nook Sal mon Ocorhyndhs tshaytsda Fry Rel eased Duri ng Screen Integrity Tests at the Sunnysi de Fi sh Screening Facility, Spring 1988

\begin{tabular}{|c|c|c|c|c|c|c|c|c|c|}
\hline \multirow{2}{*}{$\begin{array}{l}\text { TEST } \\
\text { GROP }\end{array}$} & \multicolumn{5}{|c|}{ NUMBER OF CONIROL FISH } & \multicolumn{4}{|c|}{ NUMBER OF TEST FISH } \\
\hline & $\begin{array}{l}\text { SCREEN } \\
\text { NUBER }\end{array}$ & \multicolumn{2}{|c|}{$\begin{array}{c}\text { RELEASED CAPTURED } \\
\text { FYKE NET }\end{array}$} & \multicolumn{2}{|c|}{$\begin{array}{c}\text { RELEASED CAPTURED } \\
\text { PLANE }\end{array}$} & \multirow{2}{*}{$\begin{array}{c}\text { RELEASED } \\
1045 \\
- \\
-\end{array}$} & PLANE & FYKE NET & OTHER \\
\hline $\begin{array}{l}1 \\
1 \\
1 \\
1\end{array}$ & $\begin{array}{l}5 \\
6 \\
7 \\
8\end{array}$ & $\begin{array}{l}100 \\
100 \\
100 \\
100\end{array}$ & $\begin{array}{l}98 \\
95 \\
88 \\
82\end{array}$ & $\begin{array}{l}100 \\
- \\
-\end{array}$ & $\begin{array}{l}75 \\
- \\
- \\
-\end{array}$ & & $\begin{array}{c}746 \\
- \\
- \\
-\end{array}$ & $\begin{array}{c}9 \\
1 \\
18 \\
3\end{array}$ & $\begin{array}{l}0 \\
0 \\
3 \\
0\end{array}$ \\
\hline $\begin{array}{l}2 \\
2 \\
2 \\
2\end{array}$ & $\begin{array}{l}5 \\
6 \\
7 \\
8\end{array}$ & $\begin{array}{l}100 \\
100 \\
100 \\
100\end{array}$ & $\begin{array}{l}93 \\
94 \\
95 \\
73\end{array}$ & $\begin{array}{l}100 \\
- \\
-\end{array}$ & $\begin{array}{c}80 \\
-\end{array}$ & $\begin{array}{c}1047 \\
- \\
-\end{array}$ & $\begin{array}{c}791 \\
- \\
-\end{array}$ & $\begin{array}{l}2 \\
0 \\
6 \\
3\end{array}$ & $\begin{array}{l}0 \\
0 \\
0 \\
0\end{array}$ \\
\hline $\begin{array}{l}3 \\
3 \\
3 \\
3\end{array}$ & $\begin{array}{l}13 \\
14 \\
15 \\
16\end{array}$ & $\begin{array}{l}100 \\
100 \\
100 \\
100\end{array}$ & $\begin{array}{l}62 \\
60 \\
78 \\
75\end{array}$ & $\begin{array}{c}100 \\
-\end{array}$ & $\begin{array}{l}75 \\
: \\
- \\
-\end{array}$ & $\begin{array}{c}1047 \\
\vdots \\
- \\
-\end{array}$ & $\begin{array}{c}891 \\
- \\
-\end{array}$ & $\begin{array}{l}2 \\
0 \\
3 \\
7\end{array}$ & $\begin{array}{l}4 \\
0 \\
0 \\
5\end{array}$ \\
\hline $\begin{array}{l}4 \\
4 \\
4 \\
4 \\
\end{array}$ & $\begin{array}{l}14 \\
15 \\
16 \\
17 \\
\end{array}$ & $\begin{array}{r}100 \\
100 \\
100 \\
\mathbf{9 9} \\
\end{array}$ & $\begin{array}{l}76 \\
81 \\
83 \\
77 \\
\end{array}$ & $\begin{array}{l}100 \\
- \\
- \\
\end{array}$ & $\begin{array}{c}87 \\
- \\
- \\
- \\
\end{array}$ & $\begin{array}{c}1047 \\
- \\
- \\
- \\
\end{array}$ & $\begin{array}{c}845 \\
- \\
- \\
- \\
\end{array}$ & $\begin{array}{l}0 \\
0 \\
1 \\
5\end{array}$ & $\begin{array}{l}0 \\
0 \\
0 \\
0 \\
\end{array}$ \\
\hline To & & 1599 & 1310 & 400 & 317 & 4186 & 3273 & 60 & 12 \\
\hline
\end{tabular}


TABLE 8,47. Capt ure Effi ci ency of the I ncl i ned PI ane and Fyke Nets Used During Screen Integrity Tests at the Sunnysi de Canal Fi sh Screening Facility, Spring 1988

\begin{tabular}{|c|c|c|c|c|}
\hline $\begin{array}{l}\text { SCREEN } \\
\text { SECTI ON( a) }\end{array}$ & \begin{tabular}{l}
\multicolumn{1}{c}{ PROE } \\
PLANE \\
CAPTURE \\
\end{tabular} & $\begin{array}{c}\text { ABI LI TY } \\
\text { NET } \\
\text { CAPTURE }\end{array}$ & $\begin{array}{l}\text { ESTI MATE } \\
\text { SCREEN } \\
\text { EFFI CI ENCY }\end{array}$ & $\begin{array}{c}95 \% \\
\text { CONFI DENCE } \\
\text { INTERVAL } \\
\end{array}$ \\
\hline 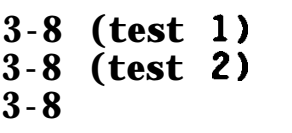 & $\begin{array}{l}0.750 \\
0.800 \\
0.775\end{array}$ & $\begin{array}{l}0.908 \\
0.888 \\
0.898\end{array}$ & $\begin{array}{l}0.967 \\
0.988 \\
0.977\end{array}$ & $\begin{array}{l}0.96-0.98 \\
0.98-1.00 \\
0.97-0-98\end{array}$ \\
\hline $\begin{array}{l}9-17 \text { (test } 3) \\
9-17 \text { (test } 4) \\
9-17\end{array}$ & $\begin{array}{l}0.750 \\
0.870 \\
0.810\end{array}$ & $\begin{array}{l}0.688 \\
0.794 \\
0.741\end{array}$ & $\begin{array}{l}0.986 \\
0.992 \\
0.989\end{array}$ & $\begin{array}{l}0.98-1.00 \\
0.99-1.00 \\
0.98-0.99\end{array}$ \\
\hline 3- 17 & 0.793 & 0.819 & 0.983 & $0.98-0.99$ \\
\hline
\end{tabular}

(a) The screens are number ed from the upst ream screen (NMBER 1) to the downst ream screen nearest the separati on chamber (NUMBR 17). Screens 1 and 2 are permanent $y$ out of servi ce.

TABLE 8, 48. Capt ure Data from Fyke Nets Behi nd Sel ected Screens at the Sunnysi de Canal Fi sh Screeni ng Faci I ity After the Rel ease of Yaki na I ndi an Nati on ( Y N) Fal I Chi nook Sal mon Ocorhyndus tstanytsda Fi ngerl i ngs From the Whpato Screens For ebay, Spring 1988

\begin{tabular}{clcc}
\hline SCREEN & & \multicolumn{2}{c}{ FYKE NET CAPTURES } \\
\cline { 2 - 4 } NUMER & NET & Y N FI SH & OTHER SALMONIDS(a) \\
\hline 7 & A(b) & 2 & 2 \\
7 & B & 0 & 0 \\
8 & A & 26 & 2 \\
8 & B & 157 & 5 \\
\hline Total & & 185 & 9
\end{tabular}

(a) I ncl udes smolt-sized and 0 age salmonids.

(b) Net A is the top net. Net B is the bottom net (Fi gure 7. this report). 
IABLE B.49. Descal ing and Mortal i ty Data from Rel ease and Capt ure Tests wi th Steel head Crorhynd mykiss and Spring Chi nook 0 . tstanytsda Snol ts at the Westside Ditch Fi sh Screening Facility, Spring 1989

\begin{tabular}{|c|c|c|c|c|c|c|c|c|}
\hline \multirow[b]{2}{*}{ SPEC ES } & \multirow[b]{2}{*}{ GROP } & \multicolumn{4}{|c|}{ NUMER } & \multicolumn{2}{|c|}{ PERCENT } & \multirow{2}{*}{$\begin{array}{c}95 \% \\
\text { CONFI DENCE } \\
\text { I NIERVAL }\end{array}$} \\
\hline & & RELEASED & CAPTURED & DESCALED & DEAD & CAPTURED & DESCALED & \\
\hline St eel head & 1 & 375 & 304 & 3 & 0 & 81.1 & 1.0 & $0-3$ \\
\hline St eel head & 2 & 375 & 321 & 8 & 0 & 85.6 & 2.5 & $1-5$ \\
\hline & $\begin{array}{c}\text { TOTAL: } \\
1\end{array}$ & 750 & 625 & 11 & 0 & 83.3 & 1.8 & $1-3$ \\
\hline Chi nook & 2 & 375 & 371 & 0 & 0 & 98.9 & 0.0 & $1-0$ \\
\hline Chi nook & & 380 & 379 & 2 & 0 & 99.7 & 0.5 & $2-0$ \\
\hline & TOTAL: & 755 & 750 & 2 & 0 & 99.3 & 0.3 & $1-0$ \\
\hline Rai nbow & (Nati ve) & - & 16 & 0 & 0 & - & 0.00 & $0-21$ \\
\hline
\end{tabular}




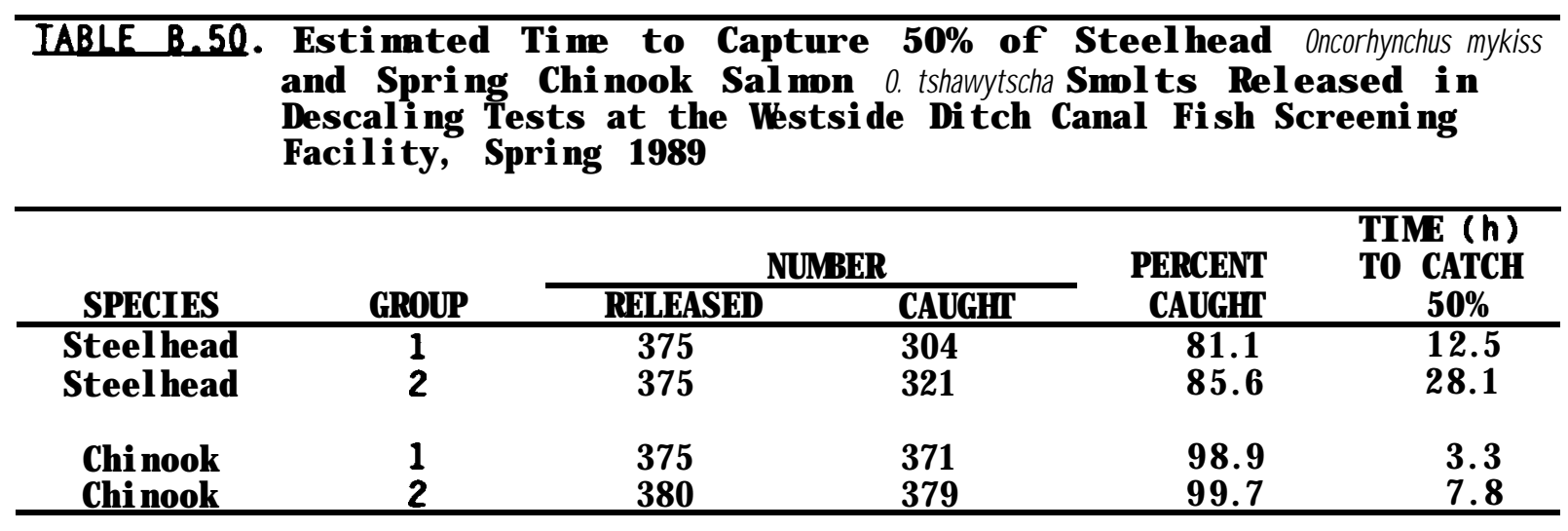

IABLE B.51. Percentage of Spri ng Chi nook Sal non Ocorbynchs tshanytscha Snol ts Descal ed in Pi pe Tests at the Whato Canal Fi sh Screening Facility, Spring 1989

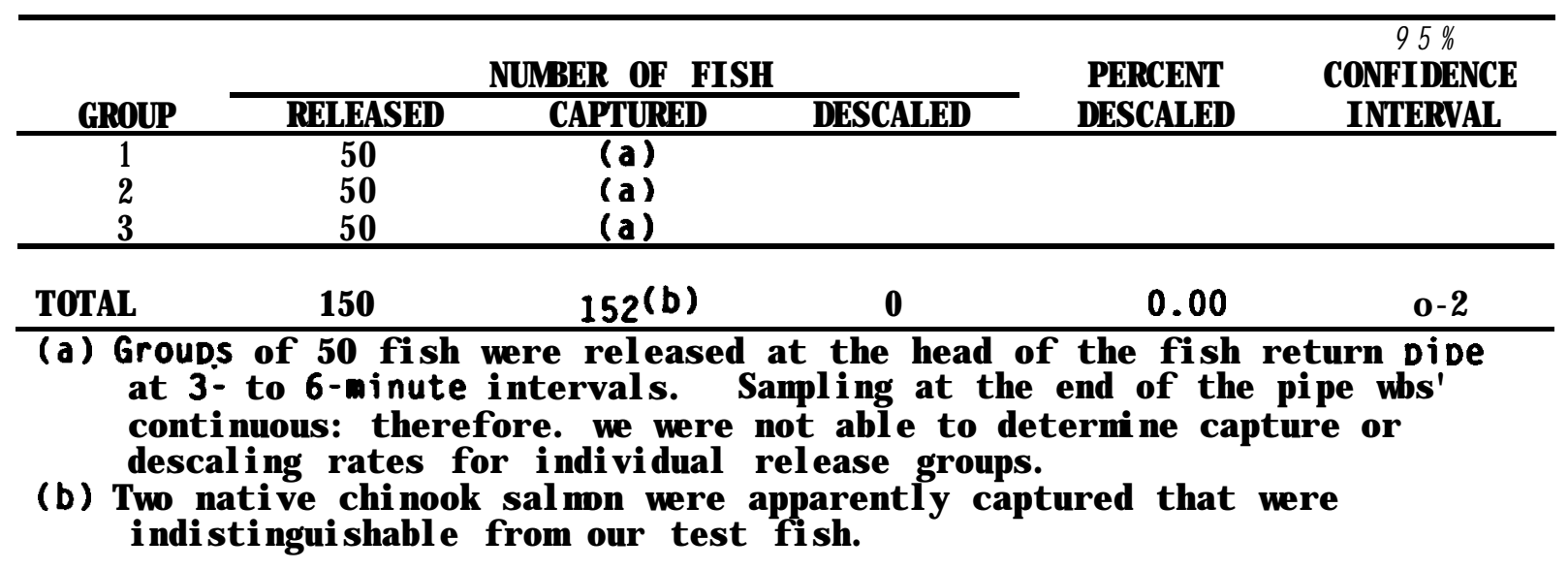


IABLE B.52. Capture Data for Rai nbow Trout Corhyndumykissfry Rel eased Duri ng Screen Integrity Tests at the Westsi de Ditch Canal Fi sh Screening Facility, Spring 1989

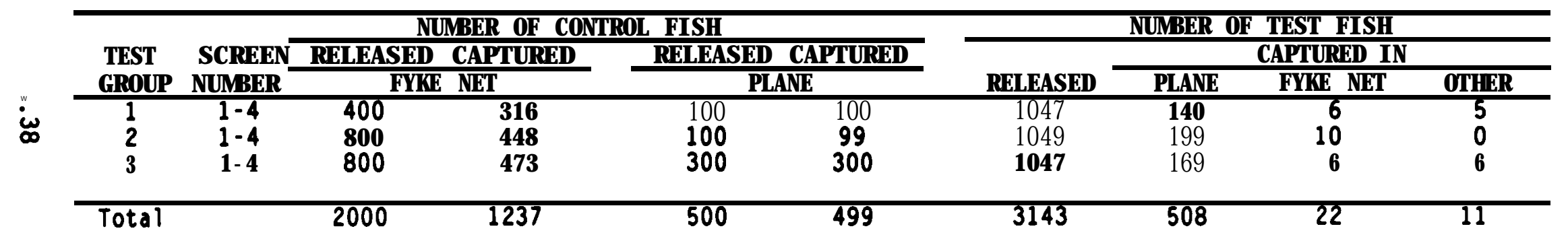




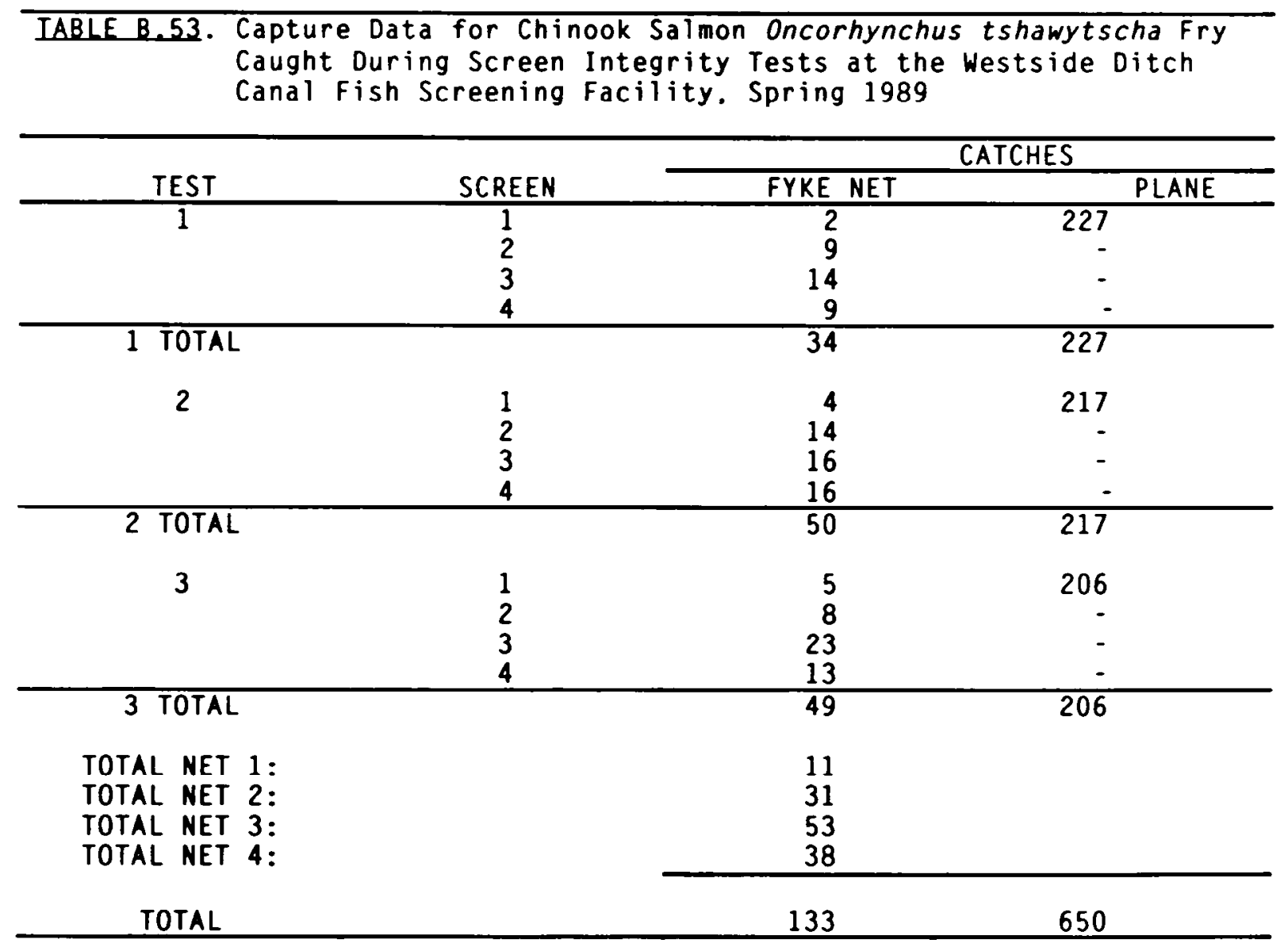

\begin{tabular}{ccccc}
\hline IABLE B.54. Capture Efficiency of the Inclined Plane and Fyke Nets Used \\
During Screen Integrity Tests at the Westside Ditch Canal Fish \\
Screening Facility. Spring 1989
\end{tabular}

